Prepared in cooperation with Bureau of Land Management, U.S. Fish and Wildlife Service, U.S. Forest Service, and Western Association of Fish and Wildlife Agencies

\title{
Greater Sage-Grouse Science (2015-17)—Synthesis and Potential Management Implications
}

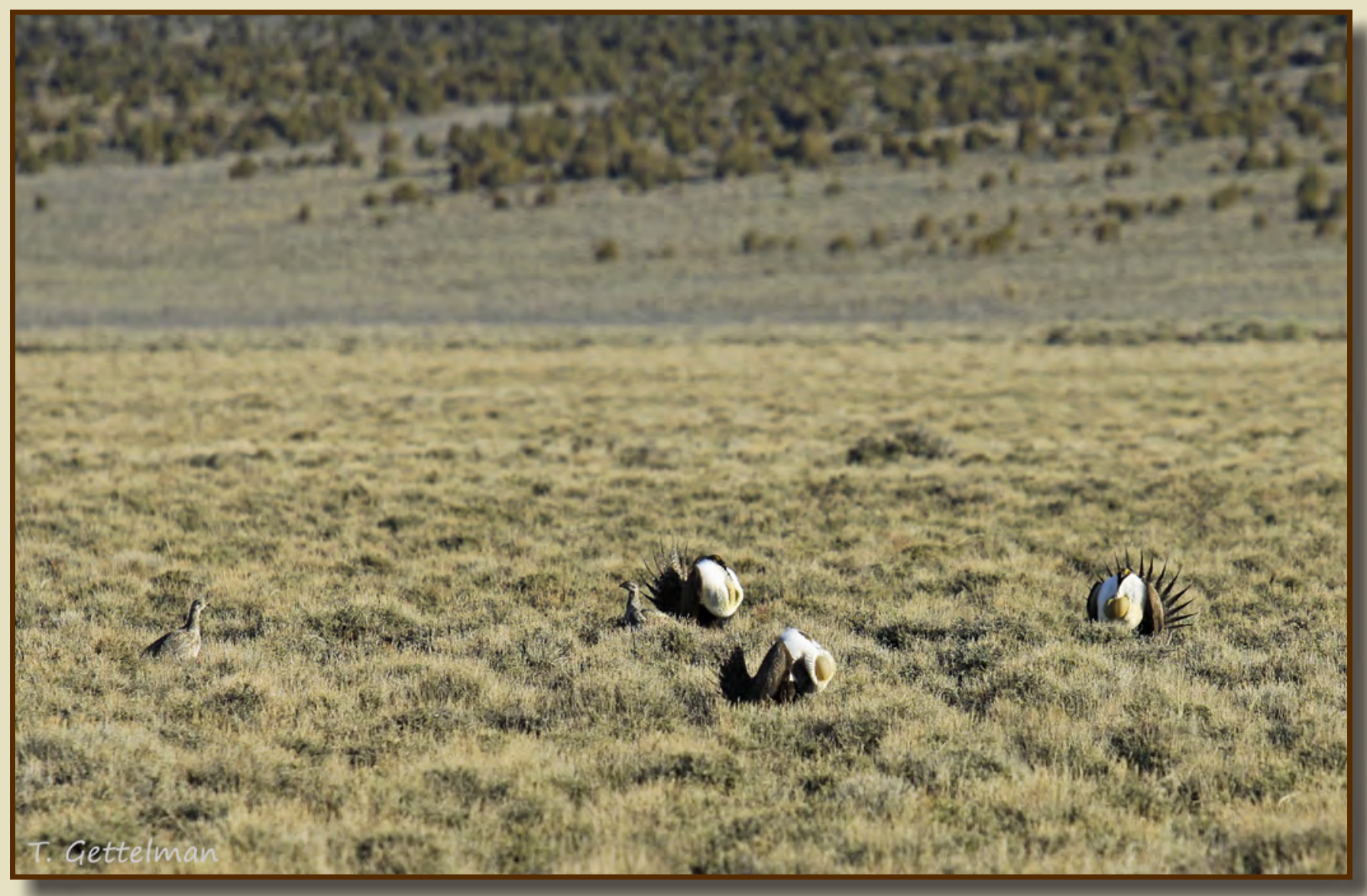

Open-File Report 2018-1017

U.S. Department of the Interior

U.S. Geological Survey 
Cover. A male and female greater sage-grouse on a lek in Nevada. Photograph by Tatiana Gettelman, U.S. Geological Survey. 


\section{Greater Sage-Grouse Science (2015-17) - Synthesis and Potential Management Implications}

By Steven E. Hanser, Patricia A. Deibert, John C. Tull, Natasha B. Carr, Cameron L. Aldridge, Travis D. Bargsten, Thomas J. Christiansen, Peter S. Coates, Michele R. Crist, Kevin E. Doherty, Ethan A. Ellsworth, Lee J. Foster, Vicki A. Herren, Kevin H. Miller, Ann Moser, Robin M. Naeve, Karen L. Prentice, Thomas E. Remington, Mark A. Ricca, Douglas J. Shinneman, Richard L. Truex, Lief A. Wiechman, Dereck C. Wilson, and Zachary H. Bowen

Prepared in cooperation with Bureau of Land Management, U.S. Fish and Wildlife Service, U.S. Forest Service, and Western Association of Fish and Wildlife Agencies

Open-File Report 2018-1017 


\title{
U.S. Department of the Interior \\ RYAN K. ZINKE, Secretary
}

\section{U.S. Geological Survey \\ William H. Werkheiser, Deputy Director \\ exercising the authority of the Director}

\author{
U.S. Geological Survey, Reston, Virginia: 2018
}

For more information on the USGS - the Federal source for science about the Earth, its natural and living resources, natural hazards, and the environment-visit https://www.usgs.gov or call 1-888-ASK-USGS.

For an overview of USGS information products, including maps, imagery, and publications,

visit https://store.usgs.gov.

Any use of trade, firm, or product names is for descriptive purposes only and does not imply endorsement by the U.S. Government.

Although this information product, for the most part, is in the public domain, it also may contain copyrighted materials as noted in the text. Permission to reproduce copyrighted items must be secured from the copyright owner.

Suggested citation:

Hanser, S.E., Deibert, P.A., Tull, J.C., Carr, N.B., Aldridge, C.L., Bargsten, T.C., Christiansen, T.J., Coates, P.S., Crist, M.R., Doherty, K.E., Ellsworth, E.A., Foster, L.J., Herren, V.A., Miller, K.H., Moser, Ann, Naeve, R.M., Prentice, K.L., Remington, T.E., Ricca, M.A., Shinneman, D.J., Truex, R.L., Wiechman, L.A., Wilson, D.C., and Bowen, Z.H., 2018, Greater sage-grouse science (2015-17)—Synthesis and potential management implications: U.S. Geological Survey Open-File Report 2018-1017, 46 p., https://doi.org/10.3133/ofr20181017.

ISSN 2331-1258 (online) 


\section{Contents}

Acknowledgments …….................................................................................................................

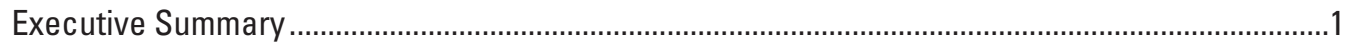

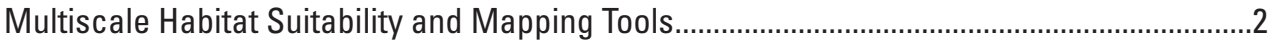

Discrete Anthropogenic Activities.....................................................................................2

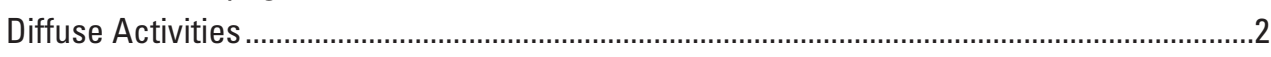

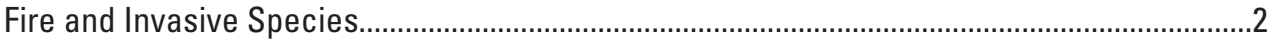

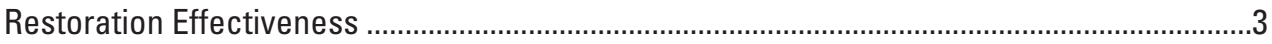

Population Estimation and Genetics......................................................................................

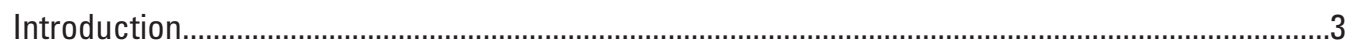

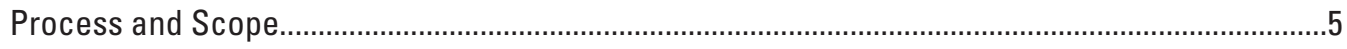

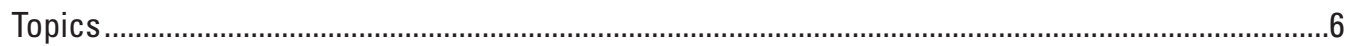

Multiscale Habitat Suitability and Mapping Tools................................................................

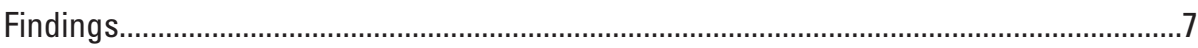

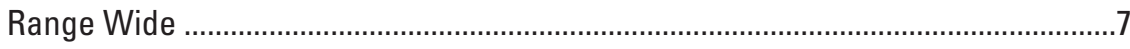

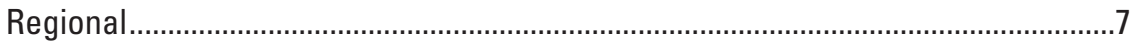

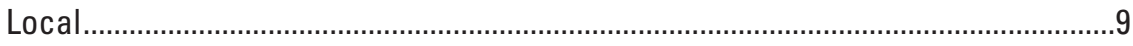

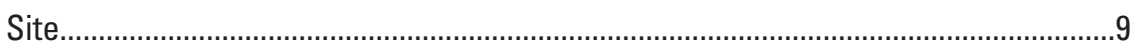

Potential Management Implic ations ........................................................................ 10

Overarching Findings and Implications ..............................................................12

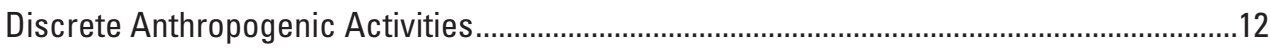

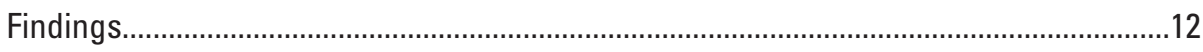

Transmission Lines and Renewable Energy....................................................12

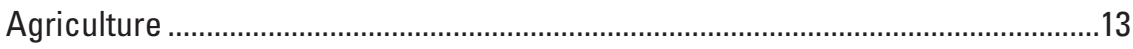

Oil and Gas Development .................................................................................13

Examination of Multiple Discrete Anthropogenic Features ......................................14

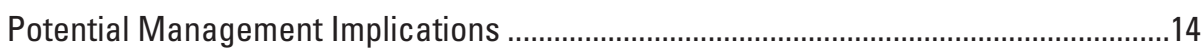

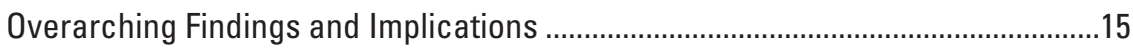

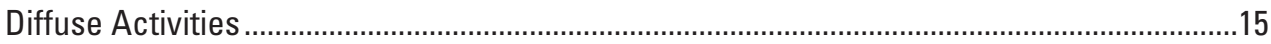

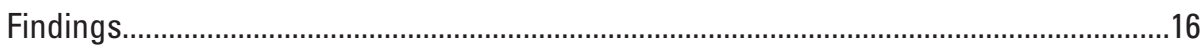

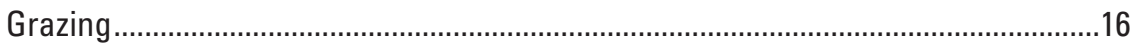

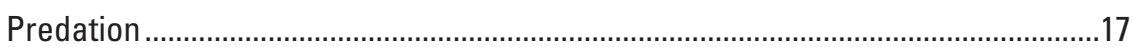

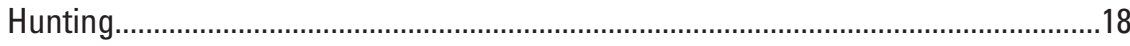

Other Diffuse Activities (Wild Horses and Burros, Fences, Recreation, and Noise) ........................................................................................... 18

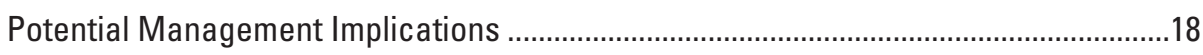

Overarching Findings and Implications ...........................................................19

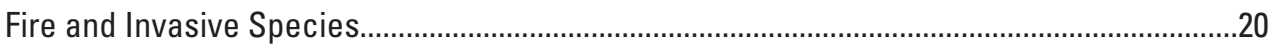

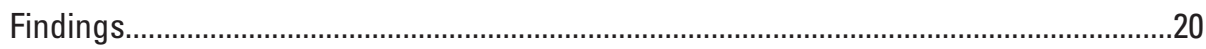

Multiscale Fire Effects on Habitat.....................................................................20

Effects of Wildfire on Habitat Selection and Demographics...................................21

Resilience and Resistance Concepts for Wildfire and Invasive Species ...............21

Predictive Habitat Modeling Based on Fire, Invasive Species, and Climate Projections 
Potential Management Implications ………………….............................................22

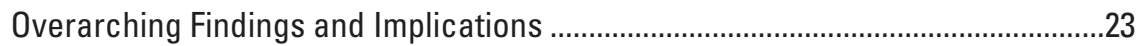

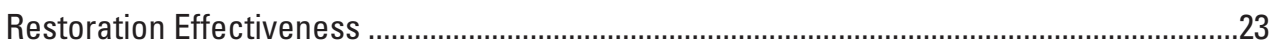

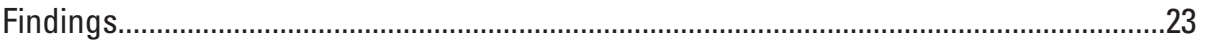

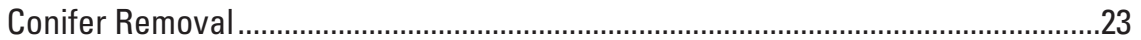

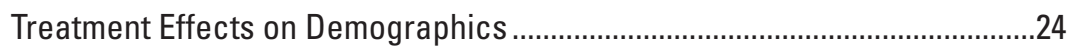

Treatment Effects on Habitat Selection Patterns ...............................................24

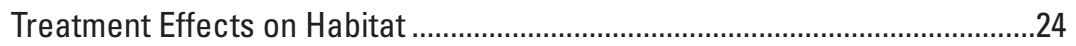

Sagebrush Manipulation and Understory Restoration...............................................24

Decision Support for Restoration Actions ...........................................................25

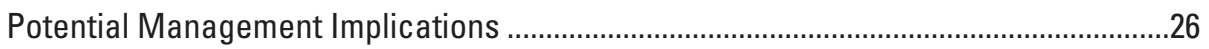

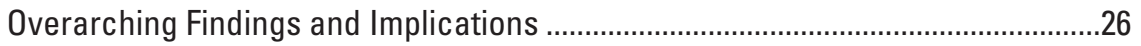

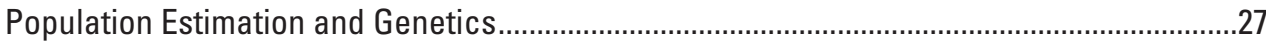

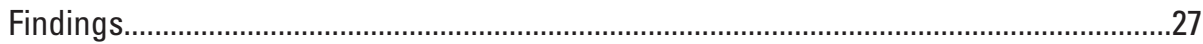

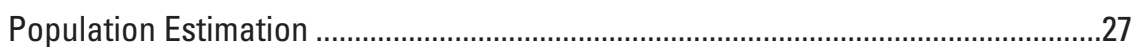

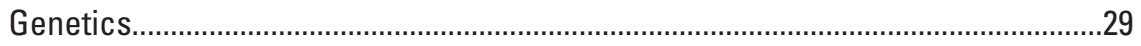

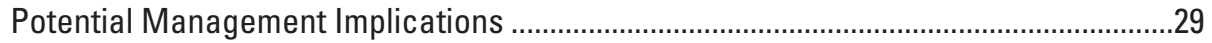

Overarching Findings and Implications .................................................................30

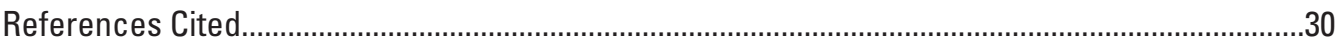

\section{Figure}

1. Map showing current and potential presettlement distribution of greater sage-grouse in North America within Western Association of Fish and Wildlife Agencies designated sage-grouse management zones

\section{Table}

1. Summary of keywords searched and numbers of publications reviewed and summarized for each of the six topic areas 


\section{Conversion Factors}

International System of Units to U.S. customary units

\begin{tabular}{lcl}
\hline \multicolumn{1}{c}{ Multiply } & By & \multicolumn{1}{c}{ To obtain } \\
\hline centimeter $(\mathrm{cm})$ & Length & inch (in.) \\
meter $(\mathrm{m})$ & 0.3937 & foot (ft) \\
meter $(\mathrm{m})$ & 3.281 & yard (yd) \\
kilometer $(\mathrm{km})$ & 1.094 & mile (mi) \\
\hline & 0.6214 & \\
\hline hectare $(\mathrm{ha})$ & Area & acre \\
square kilometer $\left(\mathrm{km}^{2}\right)$ & 2.47105 & acre \\
square kilometer $\left(\mathrm{km}^{2}\right)$ & 247.1 & square mile $\left(\mathrm{mi}^{2}\right)$ \\
\hline
\end{tabular}

\section{Abbreviations}

BLM Bureau of Land Management

DOI U.S. Department of the Interior

$\mathrm{MZ}$ sage-grouse management zone

HAF Habitat Assessment Framework

PAC Priority Areas for Conservation

USDA U.S. Department of Agriculture

USFWS U.S. Fish and Wildlife Service

USGS U.S. Geological Survey 


\section{Acknowledgments}

We thank the Bureau of Land Management (BLM), U.S. Fish and Wildlife Service, U.S. Department of Agriculture Forest Service, Western Association of Fish and Wildlife Agencies, and State fish and wildlife agencies, including Idaho Department of Fish and Game, Oregon Department of Fish and Wildlife, and Wyoming Department of Game and Fish for their cooperation and support. We thank G. Toevs (BLM), for helping formulate the vision for this report and providing helpful comments. We thank additional BLM staff, specifically 0. Bahr, J. Carlson, B. Clayton, and M. Magaletti, for helpful suggestions on improving this report. We appreciate J. Maestas (Natural Resources Conservation Service), J. Beck (University of Wyoming), K. Griffin (Colorado Parks and Wildlife), and B. Cade (U.S. Geological Survey) for providing thorough peer reviews of this report. 


\title{
Greater Sage-Grouse Science (2015-17)-Synthesis and Potential Management Implications
}

\author{
By Steven E. Hanser, ${ }^{1}$ Patricia A. Deibert, ${ }^{2}$ John C. Tull, ${ }^{2}$ Natasha B. Carr, ${ }^{1}$ Cameron L. Aldridge, ${ }^{3}$ \\ Travis D. Bargsten, ${ }^{4}$ Thomas J. Christiansen, ${ }^{5}$ Peter S. Coates, ${ }_{1}^{1}$ Michele R. Crist, ${ }^{4}$ Kevin E. Doherty, ${ }^{2}$ \\ Ethan A. Ellsworth, ${ }^{4}$ Lee J. Foster, ${ }^{6}$ Vicki A. Herren, ${ }^{4}$ Kevin H. Miller ${ }^{4}$ Ann Moser, ${ }^{7}$ Robin M. Naeve, ${ }^{4}$ \\ Karen L. Prentice, ${ }^{4}$ Thomas E. Remington, ${ }^{8}$ Mark A. Ricca, ${ }^{1}$ Douglas J. Shinneman, ${ }^{1}$ Richard L. Truex, ${ }^{9}$ \\ Lief A. Wiechman, ${ }^{2}$ Dereck C. Wilson, ${ }^{4}$ and Zachary H. Bowen ${ }^{1}$
}

\section{Executive Summary}

The greater sage-grouse (Centrocercus urophasianus; hereafter called "sage-grouse"), a species that requires sagebrush (Artemisia spp.), has experienced range-wide declines in its distribution and abundance. These declines have prompted substantial research and management investments to improve the understanding of sage-grouse and its habitats and reverse declines in distribution and population numbers.

Over the past two decades, the U.S. Fish and Wildlife Service (USFWS) has responded to eight petitions to list the sage-grouse under the Endangered Species Act of 1973, with the completion of the most recent listing determination in September 2015. At that time, the USFWS determined that the sage-grouse did not warrant a listing, primarily because of the large scale science-based conservation and planning efforts completed or started by Federal, State, local agencies, private landowners, and other entities across the range. The planning efforts culminated in the development of the 2015 Bureau of Land Management (BLM) and U.S. Forest Service Land Use Plan Amendments, which provided regulatory certainty and commitment from Federal land-management agencies to limit, mitigate, and track anthropogenic disturbance and implement other sage-grouse conservation measures.

\footnotetext{
${ }^{1}$ U.S. Geological Survey.

${ }^{2}$ U.S. Fish and Wildlife Service.

${ }^{3}$ Colorado State University, in cooperation with the U.S. Geological Survey.

${ }^{4}$ Bureau of Land Management.

${ }^{5}$ Wyoming Department of Game and Fish.

${ }^{6}$ Oregon Department of Fish and Wildlife.

${ }^{7}$ Idaho Department of Fish and Game.

${ }^{8}$ Western Association of Fish and Wildlife Agencies.

${ }^{9}$ U.S. Department of Agriculture Forest Service.
}

After these policy decisions, the scientific community has continued to refine and expand the knowledge available to inform implementation of management actions, increase the efficiency and effectiveness of those actions, and continue developing an overall understanding of sage-grouse populations, habitat requirements, and their response to human activity and other habitat changes. The development of science has been driven by multiple prioritization documents including the "Greater Sage-Grouse National Research Strategy" (Hanser and Manier, 2013) and, most recently, the "Integrated Rangeland Fire Management Strategy Actionable Science Plan” (Integrated Rangeland Fire Management Strategy Actionable Science Plan Team, 2016).

In October 2017, after a review of the 2015 Federal plans relative to State sage-grouse plans, in accordance with Secretarial Order 3353, the BLM issued a notice of intent to consider whether to amend some, all, or none of the 2015 land use plans. At that time, the BLM requested the U.S. Geological Survey (USGS) to inform this effort through the development of an annotated bibliography of sage-grouse science published since January 2015 and a report that synthesized and outlined the potential management implications of this new science. Development of the annotated bibliography resulted in the identification and summarization of 169 peer-reviewed scientific publications and reports. The USGS then convened an interagency team (hereafter referred to as the "team") to develop this report that focuses on the primary topics of importance to the ongoing management of sage-grouse and their habitats.

The team developed this report in a three-step process. First, the team identified six primary topic areas for discussion based on the members' collective knowledge regarding sagegrouse, their habitats, and threats to either or both. Second, the team reviewed all the material in the "Annotated Bibliography of Scientific Research on Greater Sage-Grouse Published since January 2015" to identify the science that addressed the topics. Third, team members discussed the science related to each topic, evaluated the consistency of the science with existing 
knowledge before 2015, and summarized the potential management implications of this science. The six primary topics identified by the team were:

- Multiscale habitat suitability and mapping tools

- Discrete anthropogenic activities

- Diffuse activities

- Fire and invasive species

- Restoration effectiveness

- Population estimation and genetics

\section{Multiscale Habitat Suitability and Mapping Tools}

Sage-grouse generally select large, intact sagebrush landscapes that are fairly flat and have little to no disturbances associated with human activities. Science developed since 2015 largely corroborated this existing knowledge regarding sage-grouse habitat selection. Advances at the landscape scale have been in development of modeling and mapping techniques to inform broad-scale habitat mapping. Consistent mapping across large areas can help inform allocation and targeting of land management resources to benefit sage-grouse conservation. At the regional and local spatial scales, advances in high-resolution geospatial data enable a better understanding of habitat characteristics and application of more powerful modeling techniques. This information complements largerscale mapping efforts to ensure that the implementation of sage-grouse conservation measures is appropriately based on regional or locally relevant habitat relations. At the site scale, a deeper understanding has been developed regarding the importance of grass height to nest success, which indicates the potential need for a reevaluation of existing, broadly applied habitat objectives.

\section{Discrete Anthropogenic Activities}

Discrete anthropogenic activities, such as energy development, power lines, roads, and cropland conversion, can have negative effects on sage-grouse, ranging from displacement of individuals to local extirpation. Scientific findings since 2015 largely substantiated past knowledge on the effects of discrete anthropogenic activity on sage-grouse, providing increased confidence in those already reported effects. Strategies to limit surface disturbance developed by local, State, and Federal land managers to address effects of discrete anthropogenic activities may be successful at limiting sage-grouse rangewide population declines, if implemented, but the conservation measures are not expected to reverse the declines, particularly where active oil and gas operations are present. In areas susceptible to agricultural conversion, targeted implementation of conservation easements on private lands may be vital to maintaining and improving connectivity for sage-grouse in some fragmented sagebrush ecosystems.

\section{Diffuse Activities}

Diffuse activities in sage-grouse habitat include livestock grazing, predation, hunting, wild horses and burros, fences, recreation, and noise. The literature since 2015 did not appreciably change current knowledge, though some studies questioned current assumptions, provided refinements, or corroborated existing understanding. Studies demonstrated that livestock grazing can have detrimental, neutral, or positive effects to sage-grouse habitats resulting in population-level effects with the directionality of impact dependent on grazing intensity and timing relative to vegetation phenology and productivity. Predation can be limiting to sage-grouse populations in areas with overabundant predator numbers or degraded habitats, and application of predator control has potential short-term benefits in small, declining populations. However, reducing anthropogenic subsidies may be necessary to generate long-term changes in raven numbers, an important sagegrouse nest predator, because raven control has only produced short-term declines in local raven populations. Refinements to the current hunting seasons used by State wildlife agencies may minimize potential effects to sage-grouse populations, but none of the studies implicated current application of hunting seasons and timings as a plausible cause for sage-grouse declines. Finally, no new insights into the effects of wild horses and burros, fence collision, recreational activity, or noise on sage-grouse have been developed.

\section{Fire and Invasive Species}

Wildfire is a large-scale threat to sage-grouse through loss of available habitat, reductions in multiple vital rates, and declining population trends, particularly in the western part of its range. Science since 2015 indicates that the threat will pose an increasing challenge as wildland fires grow larger and more frequent and are exacerbated by nonnative annual grass invasion. To inform ongoing management of sage-grouse and their habitats, the concepts of resilience after wildfire and resistance to invasion by nonnative annual grasses have been mapped across the sagebrush ecosystem using links to soil temperature and moisture regimes. These concepts form the foundation for a framework to inform effective restoration and management strategies and assist in prioritizing application of sage-grouse management resources. Potential long-term changes in wildfire behavior and nonnative annual grass invasion because of warming trends reinforce the importance of large-scale monitoring strategies and development of tools to effectively target fire suppression, place fuel breaks, and treat nonnative annual grass invasions. 


\section{Restoration Effectiveness}

The most substantial advancement for improving restoration effectiveness was the development of tools to help managers strategically place restoration treatments where they will most likely have the greatest benefit for sage-grouse populations, develop objectives for those treatments, and select the most appropriate techniques to achieve those objectives. Information provided in studies since 2015 was largely consistent with existing knowledge but provided new insights that could guide future management. Conifer removal benefited sage-grouse through increased female survival and nest and brood success. Treatment method and site potential can affect posttreatment vegetation characteristics. Sagebrush manipulation treatments seemed to benefit sage-grouse populations and brood-rearing habitat availability, but benefits may be limited to areas with high sagebrush cover at higher elevations and in mountain big sagebrush (A. tridentata vaseyana) communities. Type of treatment was important as sage-grouse populations did not benefit from, or were negatively affected by, prescribed fire and mechanical sagebrush removal treatments.

\section{Population Estimation and Genetics}

The accuracy and precision of sage-grouse population estimates has increased because of improved sampling procedures used to complete count surveys at sage-grouse breeding areas, known as leks, and the development of correction factors for potential bias in lek count data. Techniques to analyze sage-grouse population data also have advanced. This includes development of nested hierarchical population estimates to target management and use of integrated population modeling frameworks to differentiate the contribution of individual vital rates (for example, adult survival) to overall population trends. Also, advances in molecular techniques have improved mapping of sage-grouse genetic structure at multiple spatial scales, and integration of these genetic data into advanced statistical models has increased overall understanding of how landscape features and configuration affect gene flow. Genetic analyses emphasize the importance of maintaining connectivity between populations to ensure genetic diversity and distribution.

\section{Introduction}

The greater sage-grouse (Centrocercus urophasianus; hereafter called "sage-grouse") is an obligate user of sagebrush (Artemisia spp.), dependent on large areas of contiguous sagebrush to meet all seasonal habitat needs, including nesting, brood rearing, cover, and as much as 100 percent of their winter diet (Patterson, 1952; Braun and others, 1976; Connelly and others, 2000b, 2011; Miller and others, 2011; Knick and others, 2013). Sage-grouse may use multiple areas to meet seasonal habitat needs through the year (Fedy and others,
2012), and once adult sage-grouse have chosen breeding, nesting, brood-rearing, and wintering areas (Connelly and others, 2011), they rarely switch to new areas, which limits their adaptability to change (Schroeder and others, 1999).

Sage-grouse currently are present in 11 western States and 2 Canadian provinces and now occupy less than 56 percent of their potential range before European settlement in the 19th century (presettlement, fig. 1; Schroeder and others, 2004; Knick and Connelly, 2011). The actual decline in the number of sage-grouse from presettlement times is unclear as population estimates were mostly anecdotal before the development of systematic sage-grouse surveys in the 1950s (Braun, 1998). Declines in sage-grouse numbers and distribution are attributed primarily to the loss and degradation of sagebrush habitats (Connelly and others, 2000b; Schroeder and others, 2004; Knick and Connelly, 2011).

At least 50-60 percent of potential sagebrush habitat has been altered or disturbed, either through loss by direct conversion and fragmentation, or alteration of understory vegetation in remaining sagebrush (Knick and others, 2003). Habitat fragmentation can result in reductions in lek persistence, lek attendance, population recruitment, yearling and adult annual survival, female nest site selection, nest initiation, increased movement distances, and complete loss of leks and winter habitat (Schroeder and Robb, 2003; Aldridge and Boyce 2007; Walker and others, 2007; Doherty and others, 2008). Largescale disturbances (for example, agricultural conversions) within surrounding landscapes affect sage-grouse habitat selection and population persistence (Aldridge and others, 2008; Knick and Hanser, 2011; Wisdom and others, 2011). Habitat loss and fragmentation also decrease the connectivity between seasonal habitats potentially resulting in population isolation (Knick and Hanser, 2011) and loss (Doherty and others, 2008). Sage-grouse avoid areas where humans have caused sagebrush fragmentation but not naturally heterogeneous landscapes (Leu and Hanser, 2011). Functional habitat loss also contributes to habitat fragmentation, as sage-grouse avoid areas with human activity (Aldridge and Boyce, 2007), including noise, even when sagebrush remains intact (Blickley and others, 2012a).

Primary causes of sage-grouse habitat loss are anthropogenic disturbances, most notably nonrenewable energy development, conversion of sagebrush to agricultural crops, and the presence of roads, transmission lines, exurban development, and other surface disturbing activities (U.S. Department of the Interior, 2015b). Additionally, wildfire has been increasing in the western part of the sage-grouse range because of an increase in fire frequency facilitated by the invasion of nonnative annual grasses, primarily cheatgrass (Bromus tectorum) and medusahead (Taeniatherum asperum), into sagebrush ecosystems (Billings, 1994; Miller and Eddleman, 2001). The positive feedback loop between nonnative annual grasses and fires can preclude the opportunity for sagebrush to become re-established, thereby preventing natural recovery in those areas. Sage-grouse habitat loss also results from the expansion of native juniper (Juniperus spp.) and pinyon (Pinus spp.) woodland (hereafter 


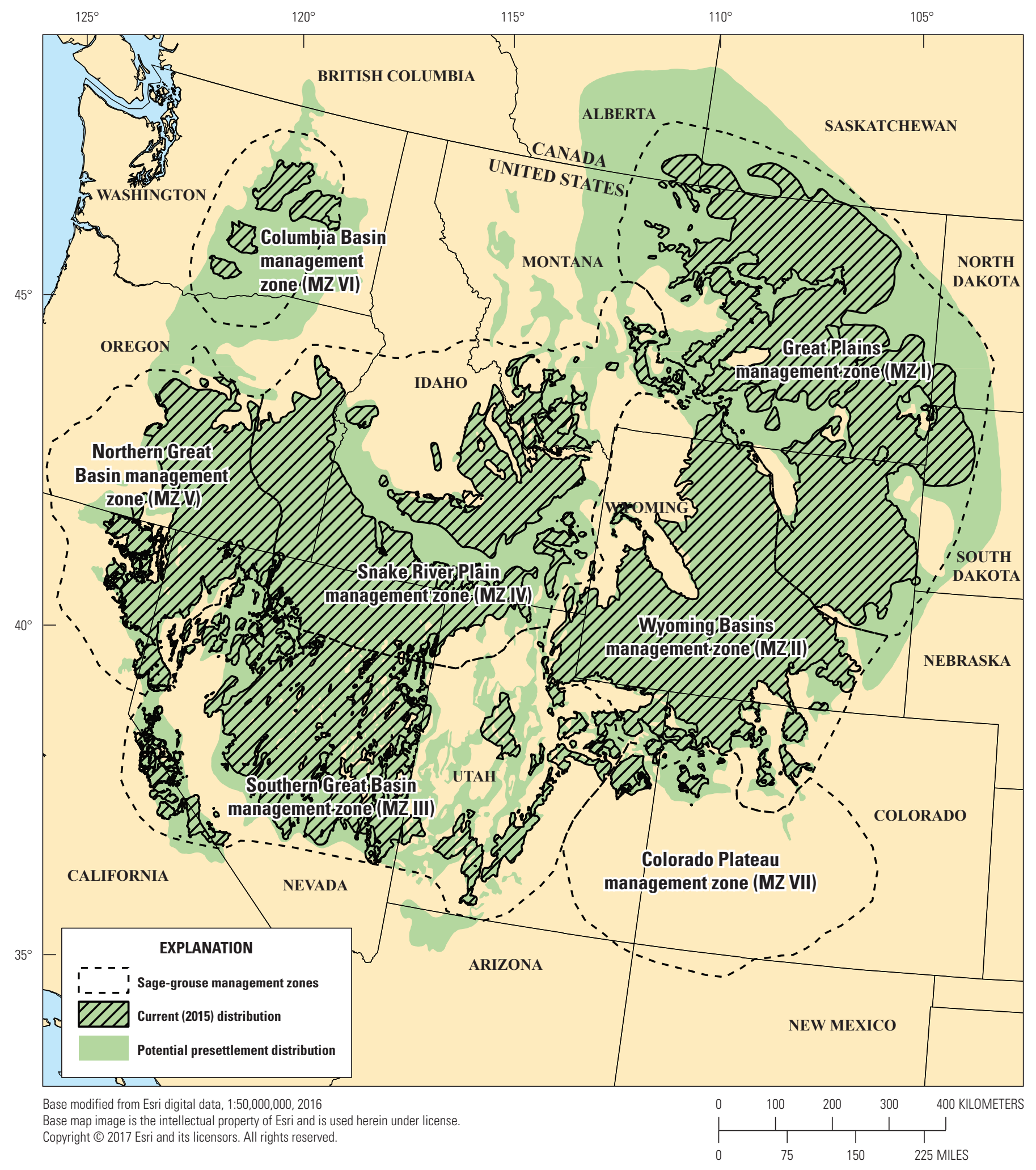

Figure 1. Current and potential presettlement distribution of greater sage-grouse in North America (adapted from Schroeder and others, 2004) within Western Association of Fish and Wildlife Agencies designated sage-grouse management zones (Stiver and others, 2006). 
called "conifers"), as encroaching conifers lead to decreases in sagebrush shrub cover and reductions in key understory food resources, and may offer perch sites for avian predators (Crawford and others, 2004, Doherty and others, 2010; Casazza and others, 2011; Baruch-Mordo and others, 2013).

Restoration of sagebrush vegetation communities is difficult because of multiple factors, including a large range of abiotic variation, minimal short-lived seed banks, the long generation time of sagebrush, and the disruption of ecological processes and loss of key components of sagebrush ecosystems since Euro-American settlement (Knick and others, 2003; Miller and others, 2011). Alteration of vegetation, nutrient cycles, topsoil, and biological soil crusts has exceeded recovery thresholds (Knick and others, 2003; Pyke, 2011), thus precluding the recovery of some areas previously dominated by sagebrush. Active restoration activities often are limited by financial and logistical resources and may require decades to succeed (Knick and others, 2003; Miller and others, 2011; Pyke, 2011). Landscape restoration efforts require a broad range of partners owing to land ownership patterns and management constraints (Knick, 2011).

Between 1999 and 2003, eight petitions were filed with the U.S. Fish and Wildlife Service (USFWS) to list the sage-grouse under the Endangered Species Act in all or parts of its range. Starting in 2005, the USFWS responded to the range-wide petitions (U.S. Department of the Interior, 2005, 2010, 2015b). The "not warranted" determination in 2005 was remanded back to the USFWS resulting in a "warranted but precluded" determination in 2010 based on new information not available in 2005 . The primary listing factors identified in 2010 were loss, fragmentation, and degradation of sagebrush habitats essential for sage-grouse survival and persistence, and the lack of sufficient regulatory mechanisms to protect those habitats from further damage and loss. Because of numerous conservation efforts and regulatory measures to conserve sage-grouse and its habitats (for example, Bureau of Land Management, 2015a, b; U.S. Department of Agriculture Forest Service, 2015a, b), in 2015 the USFWS concluded that the species was no longer warranted for listing under the Endangered Species Act. Conservation and regulatory measures for the sage-grouse that informed the 2015 decision were developed based on the best available science at the time the measures were written.

In October 2017, after a review of the 2015 Federal plans relative to State sage-grouse plans in accordance with Secretarial Order 3353, the Bureau of Land Management (BLM) issued a notice of intent to revise the 2015 land use plans (Bureau of Land Management, 2015a, b). The BLM requested the U.S. Geological Survey inform this ongoing planning effort through the development of an annotated bibliography of sage-grouse science developed since January 2015 (hereafter "Annotated Bibliography"; Carter and others, 2018) and a report that synthesizes this new science and provides a resource outlining the potential management implications. The U.S. Geological Survey convened an interagency team (hereafter "team") to develop this report, "Greater Sage-grouse Science
(2015-17) - Synthesis and Potential Management Implications," that focuses on the primary topics that are of importance to the ongoing management of the sage-grouse and its habitats.

\section{Process and Scope}

Building on the recently developed Annotated Bibliography (Carter and others, 2018), the team reviewed the science since 2015 for potential relevance to sage-grouse management by the BLM, U.S. Department of the Interior (DOI), U.S. Department of Agriculture (USDA), States, and other partners. The team focused on synthesizing the science and summarizing potential management implications. The goal of this report is to identify if scientific research on sage-grouse since 2015 has substantial implications for sage-grouse management.

Six primary topics, as supported by past and current research and known to be key factors in sage-grouse conservation, were selected to help focus the review:

- Multiscale habitat suitability and mapping tools

- Discrete anthropogenic activities

- Diffuse activities

- Fire and invasive species

- Restoration effectiveness

- Population estimation and genetics

For each topic the team used a series of keywords contained in the Annotated Bibliography (Carter and others, 2018) to identify relevant publications from the list of 169 papers published since 2015 (table 1). In several cases, publications were included for consideration in multiple topics using keyword searches (for example, energy development is a discrete anthropogenic feature that also can generate noise- a diffuse feature). Because some keywords were included for multiple topics, the content of the publication was used to determine the appropriate topic for that document or the publication was summarized under multiple topics based on the team's discretion.

The team attempted to only include publications that provided substantive content and to exclude those that merely referenced "greater sage-grouse" or a related topic but contained no specific information (for example, sage-grouse used as an example of a planning effort). Emphasis was placed on summarizing publications that added new information or insights to the existing knowledge base on sage-grouse. Within each topical area, the associated publications were classified into subtopics by the team according to their content.

If a peer-reviewed publication or report did not include the term "greater sage-grouse," it was not included in the Annotated Bibliography (Carter and others, 2018); thus, not all publications that might provide useful information for sagebrush management were included in this report. For example, 
Table 1. Summary of keywords searched and numbers of publications reviewed and summarized for each of the six topic areas.

[This information was obtained from an annotated bibliography of greater sage-grouse (GRSG) science developed since January 2015 (Carter and others, 2018 ) and was limited to publications containing the search term "greater sage-grouse." Keywords were selected by their relevance to the topic area. The total number of publications synthesized for each topic were less than those identified by the keyword search as not all publications provided new information. Column totals across all topics are greater than the total contained in the source annotated bibliography ( $n=169$; Carter and others, 2018) since each publication had at least one keyword.]

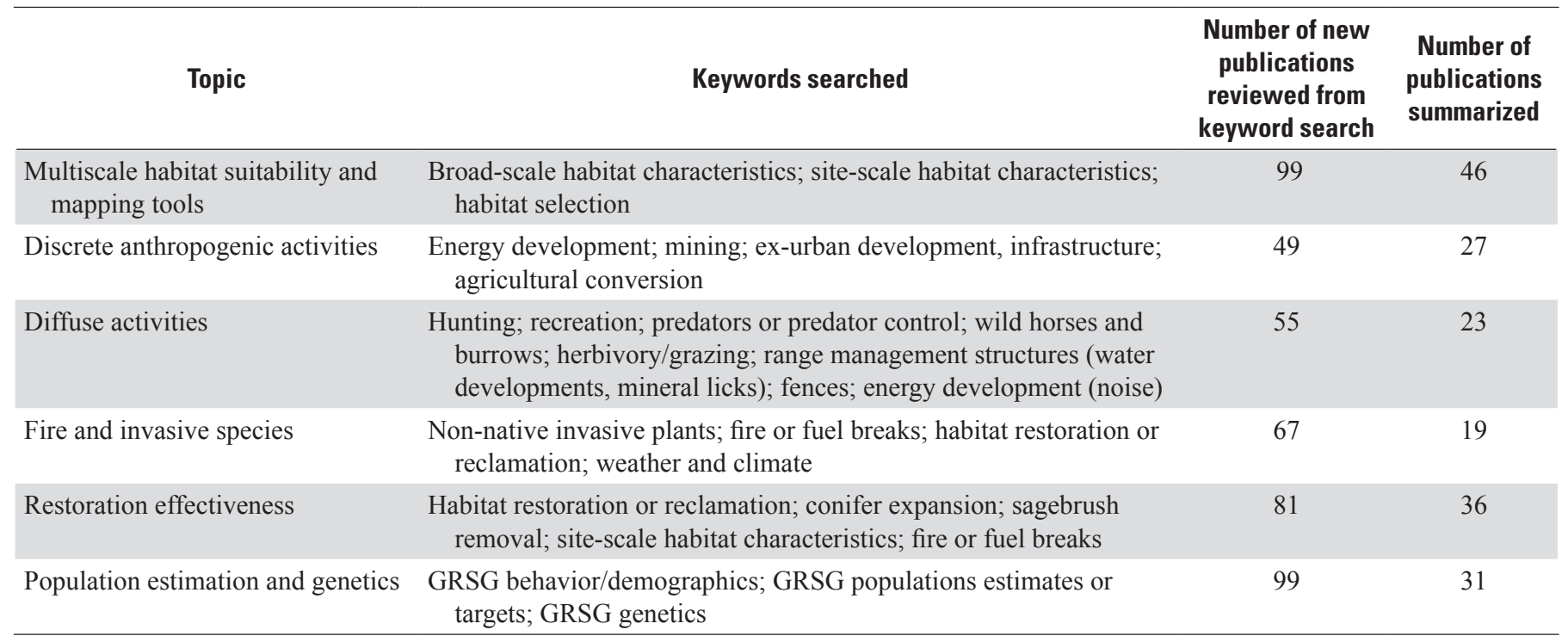

a publication providing information on sagebrush restoration or fire management techniques may be useful to managers, but if that publication did not explicitly examine the effects of these activities on sage-grouse, it was not included in this synthesis.

The following sections provide an in-depth discussion on each of the six topics. Each section includes: (1) an introduction that provides context for the topic and a brief overview of the state of knowledge prior to January 2015; (2) a summary of the science findings; and (3) a discussion of the potential management implications of this new science. The summaries of the recent science focus on the new findings, the relationship of new science to existing knowledge, and caveats for the use of the science for management, including the strength of evidence and scale of inference.

\section{Topics}

Six topics known to be important factors in sage-grouse conservation and management are the focus of this report. These sections provide information about characteristics of sage-grouse habitat, influences of multiple activities on sagegrouse populations, effects of fire and invasive species on sage-grouse and their habitat, actions to improve restoration effectiveness, and tools to determine changes in sage-grouse population size and genetic connectivity.

\section{Multiscale Habitat Suitability and Mapping Tools}

Understanding the vegetation and landscape characteristics that affect sage-grouse habitat use, survival, and reproduction has been a topic of extensive scientific investigation. Since the 1950s, biologists have worked to develop a set of site-scale vegetation measures to inform habitat management for the species, including the collection and analysis of sagegrouse habitat use, nest success, and population trends relative to vegetation condition (Patterson, 1952; Sveum and others, 1998a, b; Connelly and others, 2000b; Holloran and others, 2005; Hagen and others, 2007; Kolada and others, 2009; Kaczor and others, 2011). The existing state of knowledge for sage-grouse habitat use at the site scale has been described and synthesized (Connelly and others, 2000, 2011; Hagen and others, 2007; Stiver and others, 2015). This information was recently included in the habitat objectives tables in the 2015 BLM and U.S. Forest Service sage-grouse land use plans (Bureau of Land Management, 2015a, b; U.S. Department of Agriculture Forest Service, 2015a, b).

Advances in statistical analyses and computational power in the late 1990s facilitated the rapid expansion of resource selection function modeling (Manly and others, 2002) and statistical approaches (Burnham and Anderson, 2002). These advances also built upon emerging understanding of the importance of multiscale habitat selection (Johnson, 1980) and how 
to recognize and quantify environmental components at these multiple spatial scales (Wiens, 1989; Levin, 1992). During the past two decades, a large body of work has developed knowledge of how landscape context affects sage-grouse habitat selection, survival, and population persistence (Aldridge and Boyce, 2007; Aldridge and others, 2008, Doherty and others, 2008, Connelly and others, 2011, Wisdom and others, 2011, Knick and others, 2013). This work identified the need for large intact sagebrush landscapes with minimal disturbance that provide all seasonal components required to meet sage-grouse life history needs. Identification of landscape level thresholds and development of predictive maps have increased the ability of land managers to prioritize areas for sage-grouse conservation.

\section{Findings}

Research on multiscale habitat suitability and mapping tools published since 2015 was organized into four sub-topics based on the spatial extent of the study or type of input data including (1) range-wide; (2) regional; (3) local; and (4) site scale. These sub-topics largely align with orders of habitat selection (Johnson, 1980) and scales used in the Habitat Assessment Framework (Stiver and others, 2015). Findings of publications addressing these sub-topics are summarized below.

\section{Range Wide}

The biological conclusions for range-wide studies 201517 were largely consistent with past work, which indicated sage-grouse require large intact landscapes dominated by sagebrush cover and moderate topography with low prevalence of anthropogenic features, cropland development, and conifer cover. Relations between habitat and disturbance factors and sage-grouse breeding habitat suitability varied by sage-grouse management zones (MZs; fig. 1; Stiver and others, 2006), and a range-wide assessment of these factors identified pronounced clusters of sage-grouse (Doherty and others, 2016). This study by Doherty and others (2016) focused on identifying influential large-scale vegetation and environmental characteristics within 6.4 kilometers $(\mathrm{km})$ of lek locations, which correspond to the primary area used by sage-grouse populations (Holloran and Anderson, 2005; Doherty and others, 2011; Coates and others, 2013). Landscape cover of sagebrush was an important predictor of sage-grouse habitat in all regions, whereas conifer canopy cover and human disturbance were correlated with reductions in habitat selection across the sage-grouse range (Doherty and others, 2016). Additionally, sage-grouse within fragmented habitat areas had lower tolerance to disturbances, including areas fragmented by agricultural conversion (MZs I and VI) and conifer encroachment (MZ I), suggesting effects vary across the range. Resulting maps within this publication suggest that 80 percent of sage-grouse populations were contained in 25-34 percent of the occupied range.

Because sage-grouse require large landscapes of sagebrush throughout the year, conservation and management actions that promote healthy sage-grouse populations are likely to help other obligate and nonobligate sagebrush species (Hanser and Knick, 2011; Copeland and others, 2014). In a study of sagebrush obligate birds, all species (Brewer's sparrows [Spizella breweri], sagebrush sparrows [Artemisiospiza nevadensis], and sage thrashers [Oreoscoptes montanus]) exhibited a pronounced increase in abundance when landscape cover of sagebrush within 120 meters (m) of survey locations exceeded 40 percent (Donnelly and others, 2017); sagebrush within $6.4 \mathrm{~km}$ also was an important positive predictor. Songbird abundances were positively associated with sage-grouse distributions. For example, areas that supported the highest densities of sage-grouse populations also harbored 13-19 percent higher densities of songbirds compared with their range-wide mean densities. The colocation of these species can lead to improved targeting of conifer treatments for the benefit of both sagebrush obligate songbirds and sage-grouse simultaneously.

Range-wide connectivity of sage-grouse populations is dependent on a few large and centrally located priority areas (Crist and others, 2017). This analysis and resulting maps of sage-grouse movement potential provide a rangewide perspective regarding areas outside of primary habitat management designation that may be important targets for maintaining sage-grouse habitat suitability (see the following "Restoration Effectiveness" section).

\section{Regional}

Research done at the regional scale (that is, single or multi-State, ecoregions, and so on) often uses higher resolution sage-grouse location data (for example, telemetry) and has largely corroborated existing understanding of sagegrouse habitat associations and habitat selection patterns. For example, the negative effects of conifers on sage-grouse habitat selection were confirmed in several studies of habitat selection, including investigation of seasonal habitat use (Coates and others, 2016c, d). Negative effects of conifers on sage-grouse movement patterns were described at multiple sites, and conifer encroachment into sagebrush ecosystems resulted in faster rates of movement between seasonal habitats and increased risk of predation (Prochazka and others, 2017). The importance of mesic habitats for sage-grouse brood rearing was identified in western Nevada, eastern California, and southeastern Oregon (Donnelly and others, 2016). Several studies also added support regarding the negative effects of oil and gas development on sage-grouse habitat (Green and others, 2017; Spence and others, 2017; see the following "Discrete Anthropogenic Activities" section) and conversion from sage-grouse habitat to agricultural lands (Smith and others, 2016a). Past results on the effects of cumulative human disturbances also were validated. Landscape disturbance indices for sage-grouse habitat in northwestern Colorado were developed using distance-based and density-based approaches (Decker and others, 2017) with anthropogenic disturbance 10-12 times lower near active leks compared to historical leks. However, the authors recommend further validation of 
these models to refine their utility. Research at two study sites in central and north-central Wyoming indicated that sagegrouse selected winter habitat with gentle slopes and increased landscape cover of big sagebrush (A. tridentata) within $500 \mathrm{~m}$ (Smith and others, 2016b), which is consistent with past work (Connelly and others, 2011). Within Nevada and northeastern California, big and other sagebrush were important for sagegrouse, but species of sagebrush shrub usually varied across life stages (Coates and others, 2016c). Additionally, this study found selection for upland mesic sites during the brood-rearing season, and general avoidance of landscapes dominated by nonnative annual grass across all seasons (Coates and others, 2016c). Methodological advances in the ability to integrate multiple sources of sage-grouse location data to produce more finely tuned habitat maps across multiple seasons for use in management across Nevada and California also were demonstrated by Coates and others (2016c). Compared to prior mapping that only quantified sage-grouse habitat on an annual basis (Coates and others, 2014), use of a seasonal habitat mapping approach identified approximately 714,000 hectares (ha) more sage-grouse habitat (high, moderate, or low classification), and the total land area classified into one of the State of Nevada sage-grouse management categories (core, priority, general) increased by approximately 1 million ha.

Several studies investigated the effectiveness of existing sage-grouse conservation plans and management. These studies supported current approaches and provided valuable insights for potential future refinement. From 1999 to 2014, leks within Wyoming core areas contained 77 percent of male sage-grouse attendance and 64 percent of overall active leks (Spence and others, 2017). Additionally, the probability of lek collapse was significantly lower within core areas compared to outside core areas (10.9 percent and 20.4 percent, respectively). Importantly, the probability of lek collapse within core areas near the core area edges was significantly related to well density outside and in close proximity to core area boundaries (Spence and others, 2017; see the following "Discrete Anthropogenic Activities" section). This finding was similar to Green and others (2017), who found that development outside protected areas affected trends within protected areas.

When the core areas models were first published the authors highlighted, "there is a need to support implementation of core regions with studies that document seasonal habitat use and migration patterns of radio-marked sage-grouse to ensure identified priority landscapes meet all seasonal habitat needs" (Doherty and others, 2011, p. 513). Not surprisingly, core areas provide important protections to breeding and brood-rearing habitats in Wyoming; however, winter habitat selection in parts of five core areas within two study areas in Wyoming highlighted that existing core areas protect some but not all winter use areas (Smith and others, 2016b). These conclusions are similar when comparing derived seasonal habitat maps to the existing core areas (Dinkins and others, 2017).

In Utah, the amount of available sagebrush habitat affected distances moved between seasonal habitats, with females able to move broods over much of the landscape within more intact sagebrush habitats (Dahlgren and others, 2016b). Females moved their brood on average $1.7 \mathrm{~km}$ farther with each percent increase in sagebrush habitat availability (Dahlgren and others, 2016b), suggesting intact connected sagebrush habitat may facilitate brood movements. This study supported existing knowledge regarding the proximity of nests relative to leks ( 90 th percentile $=5 \mathrm{~km}$ ), but winter locations were farther for sage-grouse in small isolated populations than those in continuous populations (4.14 km compared to $2.70 \mathrm{~km}$ from nearest lek location, respectively). These findings point to the importance of ensuring that application of conservation buffer distances (Manier and others, 2014) is based on amount of usable habitat and incorporates all necessary seasonal habitats; in some populations, winter habitat may be quite distant from breeding habitat (Newton and others, 2017).

The importance of mesic areas to sage-grouse populations is being documented at large scales. In parts of California, Idaho, Nevada, and Oregon, Landsat remote sensing imagery, Natural Resources Conservation Service Snow Telemetry (SNOTEL) data, and other information were used to identify mesic resources (Donnelly and others, 2016). This study showed that sage-grouse abundances were higher in areas that included more persistent mesic areas through time and that 75 percent of all mesic areas were on privately owned lands.

In Wyoming, a spatially explicit individual-based simulation analysis found sage-grouse were more likely to use centrally located and easy to find habitats more than isolated habitats, and also were more likely to use areas within close proximity to different seasonal habitats (summer, winter, and nesting; Heinrichs and others, 2017a). Small and decreasing populations used less of the landscape than was potentially available according to resource selection functions, highlighting that it is not a safe assumption that all potential habitats are occupied, and populations are approaching carrying capacity when they are small or declining.

The importance of conservation easements and the Conservation Reserve Program was investigated. In the eastern part of sage-grouse range (MZ I; fig. 1), the impact of conversion to agriculture on sage-grouse populations was assessed, and benefits of targeted conservation easements were analyzed (Smith and others, 2016a). In the agricultural-affected landscape of eastern Washington, private lands enrolled in the Conservation Reserve Program provide important yearround habitats when interspersed with native sagebrush-steppe vegetation (Shirk and others, 2017; see the following "Population Estimation and Genetics" and "Discrete Anthropogenic Activities" sections).

Importantly, many of the regional studies integrated new spatial data and modeling approaches and highlighted analytical approaches that may be applied in other parts of the sage-grouse range to develop similar products in support of conservation planning efforts. New spatial data may be integrated into broad-scale strategic planning and can help inform local project implementation. For example, the 
potential value of strategically placed landscape treatments for different sage-grouse life history stages was demonstrated by Reinhardt and others (2017) through the use of a conservation planning and prioritization framework and integration of data layers on conifer cover (Falkowski and others, 2017), mesic resources (Donnelly and others, 2016), breeding habitat suitability (Doherty and others, 2016), and connectivity (Knick and others, 2013).

\section{Local}

Local-scale studies, defined as those done within small, localized study areas, completed since 2015 continue to highlight the importance of sagebrush as the defining characteristic of sage-grouse habitat across all life stages. Areas with high landscape cover of big sagebrush and low sagebrush (A. arbuscula) are important and used year-round in Oregon (Freese and others, 2016). Other characteristics that also have been previously identified as important were confirmed in these recent studies. Sage-grouse across their range select areas with low levels of anthropogenic disturbance that lack conifer trees, tend be more flat or gently rolling topography, and near water or more mesic habitats (Gibson and others, 2016b; Walker and others, 2016; Severson and others, 2017a; Zabihi and others, 2017). In Oregon, nest site selection was best predicted by shrub and forb cover and was negatively associated with areas with greater than 3 percent conifer cover (Severson and others, 2017a). If conifers were present, sage-grouse nested where the trees were clustered rather than scattered throughout the landscape, suggesting selection for more open habitats away from trees. At a site with a history of rather large wildfires, intact tracts of mountain sagebrush were important for nest site selection (Lockyer and others, 2015). In northeast Wyoming, nest success was highest in unaltered habitat after accounting for environmental predictors and amount of infrastructure, indicating that human activity also continued to be an important predictor of habitat avoidance (Kirol and others, 2015b). This work also highlighted the importance of mitigation measures that could help reduce the effects of energy development.

Several new and innovative insights into habitat selection, nest-site selection, and reproductive success were developed. Maps of habitat selection and survival facilitated the identification of habitats that contribute to the population (sources) and areas that lead to population declines (sinks) in an area of energy development in Wyoming (Kirol and others, 2015a). Combining geospatial data and field collected vegetation data provided information on scaling of habitat relations. Habitat metrics derived from geospatial data primarily informed habitat selection, whereas field collected, site-scale measures were better predictors of nest-site selection and reproductive success (Gibson and others, 2016b). Similar to the approach used by Kirol and others (2015a), the use of maps of season-specific habitat selection and survival in a lifetable response experimental approach facilitated the differentiation between areas on the landscape that act as population sources and sinks (Kane and others, 2017). This information can help inform habitat management and avoid the creation of sink habitat conditions in the future.

A further understanding of habitat characteristics important for sage-grouse was developed using a time series of sagebrush habitat components from Landsat mapping (Homer and others, 2015). In a study area in Wyoming, 30-year declines in sagebrush and increases in bare ground were largely correlated to changes in annual precipitation (Homer and others, 2015). This relation was used to map potential sage-grouse habitat changes and highlights the potential effects of longterm drought on sagebrush and sage-grouse distributions. The underlying vegetation mapping was part of a much larger effort to develop new tools for mapping sagebrush, herbaceous cover, bare ground and litter, and other sagebrush components that can help translate site-scale habitat features to mapping at the local, regional, or range-wide scales (Homer and others, 2015; Xian and others, 2015; Shi and others, 2017). Recently, this approach has been expanded to an additional study area spanning northeast Califronia, northwest Nevada, and southeast Oregon, (Shi and others, 2017) and a large-scale mapping effort to provide maps of the habitat components across the sagebrush ecosystem (Xian and others, 2015).

\section{Site}

Three papers offered new information on the relations between grass height and nest success (Gibson and others, 2016a; Coates and others 2017a; Smith and others, 2017b). Most (74 percent) previously published findings for groundnesting birds showed a positive effect of grass height on nest success if measured at the time the nest fledged its young or the nest failed (that is, nest fate), whereas grass height sampled at or corrected to the predicted hatch date tended to show little or no effect (Gibson and others, 2016a). New modeling efforts considering grass height at the predicted hatch dates for all nests (both successful and unsuccessful) concluded that sampling at nest fate may artificially increase the positive association between grass height and nest survival (Gibson and others, 2016a). In some areas, the positive relations between nest success and grass height could be an artifact based the timing of vegetation surveys rather than indicative of an effect of concealing cover on detectability by predators (Gibson and others, 2016a; McConnell and others, 2017). A subsequent nest survival study used phenologically corrected vegetation measurements to reexamine results of previous work across large parts of the sage-grouse range (Smith and others, 2017b) and provided further support for the finding of Gibson and others (2016a). Smith and others' (2017b) analyses revealed mixed support for relations between grass height and nest survival in sage-grouse; however, they did confirm that associations between grass height and nest success are frequently byproducts of when vegetation sampling was completed.

Nesting and late brood-rearing microhabitat selection and linkages to survival were quantified using extensive field data from long-term monitoring sites in xeric and mesic regions 
of the Great Basin (primarily Nevada; Coates and others 2017a). All vegetation measurements were phenologically corrected (Gibson and others, 2016a), and the authors found strong selection and positive survival consequences for high horizontal cover and total shrub cover during nesting and late brood rearing across all sites. Notably, taller perennial grasses (greater than $[>] 12.1$ centimeters $[\mathrm{cm}]$ ) were associated with successful nests in xeric but not mesic sites. Taller grasses were more available in mesic sites because of increased primary productivity, so selection of taller grasses (residual and new perennial growth) and subsequent impact on survival was stronger within xeric sites where grasses are more limiting (Coates and others 2017a). Results from this study also provide more targeted guidelines for sage-grouse microhabitat in Nevada and California compared to broader range-wide guidelines published previously (Connelly and others, 2000). For example, range-wide guidelines for suitable sagebrush cover for nests range from 15-25 percent in both mesic and xeric sites, but are narrowed to greater than 19.6 and 20.4 percent in mesic and xeric sites, respectively. Suitable perennial grass heights for nests in xeric sites in Nevada also are lower $(12.1 \mathrm{~cm})$ compared with those range wide $(>18 \mathrm{~cm}$, grass and forb combined). Suitable perennial grass heights for broods in both mesic $(>25 \mathrm{~cm})$ and xeric $(>17 \mathrm{~cm})$ sites in this region are now quantified compared with variable range-wide standards.

Additional research may be useful for improving future interpretations of habitat assessments, including the relation between soil texture to forb distribution and abundance (Pennington and others, 2017) and the relation of forbs and arthropod abundance and diversity (Schreiber and others, 2015).

However, information about forb distribution and abundance in relation to grazing, fire, chemical or mechanical treatments, and climate is scarce (Pennington and others, 2016).

Several publications since 2015 support existing knowledge with findings that were consistent with Connelly and others (2000b) habitat guidelines (Dzialak and others, 2015; Mabray and Conover, 2015; Stonehouse and others, 2015; Dinkins and others, 2016b; Gruber-Hadden and others, 2016; Smith and others, 2017a). Additional papers contained results that largely supported existing knowledge but also contained several noteworthy findings:

- Consideration of annual variation in nesting cover is essential when evaluating nesting habitat suggesting that management objectives might be different in drought years (Hansen and others, 2016a; Gibson and others, 2017).

- Adult females in areas impacted by wildfire 10 years prior tended to use other shrubs for nesting cover, suggesting that other shrub species might need to be considered in evaluations of fire-affected environments (Lockyer and others, 2015; Coates and others, 2017a).

- Nest-site selection was more predictive of chick survival than brood survival when compared with brood habitat characteristics, suggesting that hens selected nest sites based on the area's qualities as early broodrearing habitat, in addition to nesting habitat (Gibson and others, 2016b).

- Owing to a lack of available information, distance to trees or tree cover is not typically considered in site-scale evaluations of late brood-rearing habitat. New research found that hens and broods avoided pinyon-juniper by at least $68 \mathrm{~m}$ in the bi-State area of Nevada and California (Coates and others, 2016a), and a model considering late brood-rearing habitat concluded hens and broods avoided edges with trees (either conifers or tall willows; Westover and others, 2016).

- An evaluation of prenesting diets of hens on winter range in Utah found that most foraging sites (73 percent) were in black sagebrush (A. nova; Wing and Messmer, 2016). Whereas other studies have documented the use of the dwarf sagebrushes (A. nova, $A$. arbuscula) in winter, this result suggests that sagebrush height may not be an appropriate indicator of winter habitat quality in all places and years.

\section{Potential Management Implications}

The suite of publications that provide range-wide, regional, local, and site scale information has helped to further refine the overall understanding of habitat characteristics important for sage-grouse habitat selection. Resulting data and mapping products can be used to inform planning efforts across resource planning units or guide management actions so effective conservation and treatments are used within the appropriate landscape context.

Range-wide tools that have been developed provide consistent frameworks for agencies as they work to manage across the large extent of sagebrush habitat required for occurrence of sage-grouse. These models highlight that not all sage-grouse areas are created equal but the models can serve as a consistent currency to assess the overlap of sage-grouse habitats and populations with conservation actions or threats. These broad-scale products are powerful because they use consistent methods for mapping while accounting for important regional differences. This can in turn help provide for improved consistency in land management decisions within a region, even when the region is bisected by administrative or political boundaries. However, information developed and gained at smaller scales can elucidate important localized relations to habitats that can be smoothed over when looking at a range-wide or management zone extent, but are important when designing and delivering localized habitat treatments.

Although the state of knowledge regarding the relation of sage-grouse to their habitats has largely remained unchanged during the past 3 years, the application of innovative methods has increased information about the potential effects 
of management decisions and helped target the part of the landscape where different management actions may be most effective.

Sage-grouse habitats and breeding bird density were modeled, making a consistent and relative ranking of the importance of areas to sage-grouse available for range-wide management decisions (Doherty and others, 2016). Similarly, recognition of differences in climate, invasive species, and fire regimes are important for understanding and managing sagegrouse habitats and the entire sagebrush biome (Chambers and others, 2017a). Although basic knowledge of these threats is not new in the literature, expanding on this knowledge with better information in a spatial framework provides land management practitioners a tool to better manage the suite of discrete and diffuse activities based upon the resilience and resistance of landscapes to invasive species (Chambers and others, 2017a). Lastly, when the above models are combined with new analyses that rank the relative importance of sagegrouse priority areas defined for management, this can further improve understanding of habitat connectivity across the landscape (Crist and others, 2017).

Several studies at the regional scale developed important spatial modeling tools and products that can be used in both programmatic planning, including land allocations designed to conserve sage-grouse, and project-level planning and implementation (for example, Coates and others, 2016c; Donnelly and others; 2016). Though these studies have been completed for specific geographies, the methods can be applied to other areas to deliver similar planning tools. Research that examined the efficacy of existing conservation approaches for sage-grouse also highlighted the importance of ensuring areas designated to promote broad-scale sage-grouse conservation adequately consider all seasonal habitats (for example, Smith and others, 2016b) and the importance of spatial juxtaposition of conservation easements (Smith and others, 2016a) or Conservation Reserve Program enrolled private lands (Shirk and others, 2017) relative to other sage-grouse landscape habitat features.

Increased sagebrush cover and minimization of disturbance were consistent characteristics of healthy sage-grouse habitat. The strength and consistency of these relations from range wide to local provides managers with information and a set of tools for understanding the potential effect of management actions on habitat conditions for sage-grouse. For example, analysis of mitigation measures for a single energy development field (Kirol and others, 2015b) and development of source-sink maps that inform the prioritization of areas for conservation (Kirol and others, 2015a; Kane and others, 2017) identify opportunities to maintain local populations and provide opportunities for colonization of reclaimed sites after energy extraction. These models have an additional advantage of being tuned to smaller extents that generally allows better spatial predictions. New habitat mapping tools developed at local scales can often provide important insights that can be expanded through additional work (for example, Homer and others, 2015). Areas where there is alignment of habitat selection, nest site selection, and reproductive success can help identify important locations across the landscape and may help with the targeting of conservation actions and mapping critical habitats (Gibson and others, 2016b).

At the site scale, evidence for a ubiquitous positive relation between grass height and nest success was either greatly diminished (Gibson and others, 2016a) or not supported (Smith and others, 2017b), although some studies that corrected for phenology still support this relation (Smith and others, 2017b; Coates and others, 2017a). The absence of support for a universal effect of grass height does not imply nest concealment is unrelated to nest survival in sage-grouse (Smith and others, 2017b). Factors contributing to nest concealment include cover and height of shrubs and live and residual herbaceous vegetation (grasses and forbs). Several recent papers illustrated a positive relation between visual obstruction and nest and brood-rearing site selection and survival (for example, Schreiber and others, 2015; Dinkins and others, 2016b; Hansen and others, 2016a; Coates and others, 2017a). A nestsite selection meta-analysis by Hagen and others (2007) found selection for more sagebrush cover and taller grass when compared with what was available at random in the surrounding area, although effect sizes were larger for sagebrush cover and relatively small for tall grass. For example, in Nevada the mean horizontal cover at nest site locations was 14.9 and 17.4 percent greater than random locations within xeric and mesic sagebrush sites, respectively (Coates and others, 2017a). Additionally, of those used locations the authors reported horizontal cover at successful nests was 4.6 and 5.2 percent greater than unsuccessful nests at xeric and mesic sites, respectively. Similar patterns were identified when investigating vertical cover at nest sites.

The relation between sage-grouse and vegetation measures will likely vary across the range of sage-grouse (Coates and others, 2017a). Indeed, careful consideration should occur before extrapolating results of studies in one management zone into others, especially if they have vastly different ecological contexts (Doherty and others, 2016), and caution is advised when deriving site-scale habitat objectives from correlative patterns (Smith and others, 2017b). Indicator values for grass height contained in the habitat objectives tables of the 2015 BLM land use plans (Bureau of Land Management, $2015 a, b)$ may need to be examined to ensure they have not been derived from studies using vegetation data collected at different times for successful and unsuccessful nests without applying correction factors (Gibson and others, 2016a) and that science findings are geographically appropriate. In addition, the Habitat Assessment Framework (HAF; Stiver and others, 2015), which is used by the BLM and USDA Forest Service to evaluate whether public lands are meeting habitat requirements of sage-grouse, includes guidelines for grass height based largely on studies that might have measured grass height at nest fate and artificially inflated the positive effect of grass height on nest success (Smith and others, 2017b). However, grass height is just a single indicator among a large suite of indicators of site-scale habitat suitability. It is important 
to use a preponderance of evidence approach to determine overall suitability of a plot instead of using a single indicator (Pellant and others, 2005; Stiver and others, 2015).

\section{Overarching Findings and Implications}

Tradeoffs exist between local scale studies, which are often more useful for specific habitat project decisions, compared to range-wide models that allow consistent comparisons across large landscapes for policy level decisions. New regional scale modeling efforts, such as Coates and others (2016c, d), allow a finer resolution tool for conservation decisions and these analyses often have additional data available including seasonal habitat and information on radio marked birds. Likewise, local scale analyses are likely to be better suited to explain localized vegetation selection patterns and provide tools that are well suited to inform habitat conservation project decisions. Individual studies provide insights into sage-grouse habitat requirements that may vary between areas. However, caution is advised when extrapolating beyond the particular study area in which they were completed, as regional variation in habitat selection has now been documented range wide (Doherty and others, 2016).

- Science developed since 2015 largely corroborates existing knowledge regarding sage-grouse habitat selection. Sage-grouse select large intact sagebrush landscapes that are fairly flat and have very low human disturbances in any form.

- The largest advances at the range-wide scale have been in development of modeling and mapping techniques to inform broad scale habitat assessment. Consistent mapping across large areas can help inform allocation and targeting of land management resources to benefit sage-grouse conservation.

- At the regional and local scales, higher resolution geospatial information increases understanding of habitat characteristics and facilitates more powerful modeling techniques. This information complements larger-scale mapping to ensure implementation of sage-grouse conservation measures are based on appropriate regional or locally relevant habitat relations.

- At the site scale, evidence for consistent positive relations between grass height and nest success across the range of sage-grouse was not supported after identification of an issue related to timing of vegetation surveys. This may require a reevaluation of grass height metrics for sage-grouse breeding habitat. This new finding only relates to analyses of nest success when grasses were measured at the time the nest fledged its young or failed without applying a correction to account for grass phenology. Conclusions of studies using appropriate methods or correction factors to assess importance of grass height for nest success remain valid, and the large body of literature regarding importance of other site-scale vegetation measures, especially sagebrush cover, for sage-grouse habitat use and survival remains vital for setting sagegrouse habitat management objectives.

\section{Discrete Anthropogenic Activities}

There is a substantial body of scientific literature concluding that discrete anthropogenic activities that are present in sagebrush have negative effects on sage-grouse (for example, Knick and others, 2011; Manier and others, 2013). The extent of these effects vary based on the size, intensity and persistence of the human activity, and can range from displacement to local extirpation of sage-grouse (Walker and others, 2007; Becker and others, 2009; Hagen and Anthony, 2010; U.S. Fish and Wildlife Service, 2013). Both nonrenewable and renewable energy developments and their supporting infrastructure are a pervasive, and in some cases an increasing, presence within the range of sage-grouse. Other discrete anthropogenic activities associated with habitat loss and fragmentation and disturbance to sage-grouse, including agricultural conversion of sagebrush habitats and expanding urban development in sagebrush habitats, have been summarized previously (Knick and others, 2011).

Most conservation plans for sage-grouse rely in part on temporal or spatial restrictions to avoid or minimize effects of these discrete activities. The extent of the restrictions varies depending on the type and longevity of effect. Recommendations for minimizing these effects have been outlined previously (Sage-grouse National Technical Team, 2011; U.S. Fish and Wildlife Service, 2013; Manier and others, 2014).

However, there continues to be emerging science quantifying effects and measuring the efficacy of conservation recommendations. Review of this new information as it becomes available, and incorporating changes if appropriate, are essential to implementing valid conservation recommendations.

\section{Findings}

Research on discrete anthropogenic activities published since 2015 largely focused on four sub-topics, including (1) transmission lines and renewable energy; (2) agriculture; (3) oil and gas development; and (4) multiple discrete anthropogenic features. Findings of publications addressing these sub-topics are summarized below.

\section{Transmission Lines and Renewable Energy}

Since 2015, only one experimental study was published (Hansen and others, 2016b) and another summarized the most recent literature relative to avian (including sage-grouse) interactions with renewable energy infrastructure (Smith and Dwyer, 2016). Neither of these studies identified additional effects on sage-grouse that were not previously known, and 
both corroborated existing understanding. Habitat modeling efforts also corroborated existing information. Sage-grouse occurrence increased as distance from a transmission line increased in Washington State; the maximum probability of occurrence was farther than $10 \mathrm{~km}$ from the transmission line (Shirk and others, 2015). Additional research reported that leks were greater than $1 \mathrm{~km}$ from distribution lines, as well as roads and trees, and home ranges were greater than $6 \mathrm{~km}$ away from single 115 kilovolt $(\mathrm{kV})$ transmission lines (Stonehouse and others, 2015). Sage-grouse in this study especially avoided smaller distribution lines (about $12 \mathrm{kV}$ ) within their home range, which is consistent with previous research. An association between the presence of power lines and other anthropogenic features (for example, fence posts, garbage dumps) and raven occurrence (which could result in increased predation on sage-grouse) was reported by Coates and others (2016b), but the relation was small. Information gaps regarding effects of power lines on sage-grouse remain (Smith and Dwyer, 2016), some of which may be addressed by ongoing long-term before-after-control-impact research in Nevada that is expected to be completed soon. In addition, research on sage-grouse response to $230-\mathrm{kV}$ transmission lines associated with a wind energy facility in Wyoming is currently under review.

Research specific to wind energy infrastructure and sage-grouse is extremely scarce. Lek counts declined more severely near wind infrastructure after a 3 or 5 -year time lag in Wyoming (LeBeau and others, 2017a). Effects of wind infrastructure on lek attendance were weakly evident within $1.5 \mathrm{~km}$ from a turbine, and no evidence of decline beyond that distance. In an additional study at the same location, females and their chicks used brood-rearing and summer habitats farther from wind infrastructure than what was previously documented (LeBeau and others, 2017b). However, survival rates were higher on the wind facility site relative to the undisturbed site, perhaps because of lower numbers of avian predators.

\section{Agriculture}

New research on agricultural conversion is limited to narrow geographic scopes where the threat of conversion is highest. Research in MZ I (fig. 1) suggests that half of known active leks risk extirpation if greater than 22 percent of the landscape is in cropland (Smith and others, 2016a), which corroborates previous investigations. Furthermore, converting a single square mile of native sagebrush to cropland can strongly reduce persistence of leks in a landscape 10 times the size of the field itself (Smith and others, 2016a). Two studies from eastern Washington found that privately owned lands, sparsely vegetated or in the Conservation Reserve Program, may provide important habitat features for sage-grouse for nesting and seasonal habitats, and during migration (Shirk and others, 2015; Stonehouse and others, 2015); however, these lands needed to be near sagebrush patches to be effective (Shirk and others, 2015). Conversion of these lands back to active cultivation reduces or eliminates their benefit to sage-grouse. In eastern Washington, Conservation Reserve Program lands may be key to maintaining and improving connectivity for sage-grouse between extremely fragmented sagebrush communities (Shirk and others, 2015). These papers indicate the importance of maintaining private lands in native sagebrush or other permanent cover to maintain sage-grouse in some parts of its range.

\section{Oil and Gas Development}

Before implementation of the State of Wyoming's Core Area Strategy, lek attendance was correlated negatively with density of oil and gas wells (Green and others, 2017). Sagegrouse respond to development densities at multiple spatial scales surrounding leks with a 1- to 4-year time lag between oil and gas development and lek decline (Green and others, 2017). A possible explanation for a delayed response is that oil and gas development negatively affects sage-grouse recruitment into a breeding population (Green and others, 2017; but see Zabihi and others, 2017) rather than causing avoidance of an area or negatively affecting survival. Increasing density of oil and gas wells was correlated with decreasing lek attendance and effects on lek attendance were observed at a distance of $6.4 \mathrm{~km}$ from leks. Lek attendance was stable when no wells were present within $6.4 \mathrm{~km}$ of a lek and began declining after the addition of the first well. Allowable well densities that average one well pad per 640 acres within Core Areas may only be sufficient for limiting population declines to current rates but not for reversing the trend (Green and others, 2017). These analyses corroborated the findings of Gregory and Beck (2014) that suggested a maximum development density of one well pad within $2 \mathrm{~km}$ of leks to avoid measurable effects within 1 year and less than six well pads within $10 \mathrm{~km}$ of leks to avoid delayed effects. Other recent publications corroborated the negative relation between oil and gas development and sage-grouse populations or important life-history behaviors (Fedy and others, 2015a; Kirol and others, 2015a, b; Edmunds and others, 2017; Spence and others, 2017).

Several efforts have assessed the conservation actions adopted in the 2015 BLM and USDA Forest Service Land Use Plan Amendments (Bureau of Land Management, 2015a, b; U.S. Department of Agriculture Forest Service, 2015a, b) to estimate how effective the conservation actions may be at limiting effects to sage-grouse. Current conservation actions in MZ I and II (fig. 1) reduced the future exposure of sage-grouse to oil and gas development by about one-third and two-thirds, respectively (Juliusson and Doherty, 2017). The probability of lek collapse in Wyoming core areas was positively associated with development density outside the core area, and the risk of lek collapse decreased as distance from the edge increased up to a distance of $4.83 \mathrm{~km}$ from the core area boundary (Spence and others, 2017). The rate of decline was minimized for leks that were more than $4.83 \mathrm{~km}$ inside a core area, and oil and gas well densities inside core areas were unrelated to the probability of lek collapse. The conclusions of this research (edge effects of development on core areas) are not unique, but 
Spence and others (2017) provide quantification of the extent of those effects, which had not previously been evaluated for sage-grouse. These results, and those presented by Gamo and Beck (2017), support the conclusion that overall the Wyoming Governor's Executive Order is helping safeguard critical sagegrouse habitats at the State-wide scale. Other recent research is consistent with past findings that the implementation of certain mitigation techniques or design features for oil and gas operations may be beneficial in reducing, but not eliminating, adverse effects to sage-grouse (Fedy and others, 2015a; Garman, 2017; Holloran and others, 2015; Kirol and others, 2015b).

The use of seasonal habitats was addressed in several articles, the results of which were consistent with previous findings (Holloran and others, 2015; Kirol and others, 2015a; Rice and others, 2016). Novel information was provided by Smith and others (2016b), who reported sage-grouse from some core area populations moved to winter habitats outside designated core areas. These winter areas were within sagegrouse lek-based breeding buffers but were outside core area boundaries defined by breeding density and human land use. The study also found sage-grouse may use winter habitats for a longer period than is identified by current regulatory restrictions in Wyoming.

Almost all the recent studies provided relevant important information regarding future lines of inquiry or improvements for future observations (such as Fedy and others, 2015b). This information may be considered when developing future research proposals or monitoring protocols.

\section{Examination of Multiple Discrete Anthropogenic Features}

Most of the above papers examined a singular discrete anthropogenic feature or activity; however, many of the publications simultaneously modeled multiple discrete anthropogenic features. Three publications examined the potential effects of these features on connectivity among populations and subpopulations of sage-grouse. Two focused on building and testing genetic techniques for examining connectivity based on the role of anthropogenic and natural features (Row and others, 2016) and croplands on sage-grouse connectivity (Row and others, 2017). A third study corroborated a previous investigation concluding that a transmission line and State highway did not impede connectivity between sage-grouse populations within a limited study area (Jahner and others, 2016). The results of this study were likely the consequence of lek philopatry and the presence of poor habitat separating two populations. All three studies emphasized the importance of maintaining connectivity between populations to conserve genetic diversity (see the following "Population Estimation and Genetics" section).

Three papers confirmed existing understanding of the effects of discrete anthropogenic features on habitat selection while exploring new techniques (or scales) for delineating seasonal habitats. These studies reported negative responses to ex-urban development on brood-rearing habitats (Westover and others, 2016), well pads and roads on nesting habitat (Zabihi and others, 2017), and human disturbance on all habitats once sagebrush landscape cover is reduced to a level where sage-grouse occupancy is negatively affected (Doherty and others, 2016). No nests were found within $400 \mathrm{~m}$ of a road in western Wyoming (Zabihi and others, 2017), consistent with previous research. Power lines had no measurable effect on brood use in one area of Utah, but the authors did not identify whether the power lines were transmission or distribution lines, and acknowledged that occurrence does not reflect any information on brood fitness or survival (Westover and others, 2016). They also cautioned that the power line may have been placed in areas of excellent brood habitat and brood occurrence in those areas was a result of philopatry.

The quantification of habitats provided by Doherty and others (2016) validated previous intuitive conclusions regarding the lack of tolerance for continued or additional human disturbance in highly fragmented habitats with low landscape cover of sagebrush, and that MZs I and VI (fig. 1) were the most highly fragmented habitats within the range of the sage-grouse. Given the variability in habitat responses across the species' range, Doherty and others (2016) caution about extrapolating thresholds developed in one area to the other. When no other knowledge exists they recommended that the lowest thresholds of human disturbance be implemented as conservation measures, or that thresholds be developed regionally, and a robust monitoring and adaptive management program be implemented (Doherty and others, 2016).

\section{Potential Management Implications}

No substantial new information was identified in the review of the literature since 2015 regarding effects of discrete anthropogenic activity (energy development, power lines, roads, agricultural conversion) on sage-grouse, although some information was developed that continues to add to the understanding of these activities. Agricultural conversion has previously been identified as a threat to sage-grouse (Knick and others, 2011; U.S. Fish and Wildlife Service, 2013), and although new literature on this topic was limited, the results were consistent with earlier research noting that lek extirpation increases as the amount of surrounding cropland increases. Private lands enrolled in the Conservation Reserve Program lands in areas with highly fragmented sagebrush can provide important habitat features for nesting and seasonal habitats, and during migration, which is consistent with the literature published before 2015. Conversion of these lands back to active cultivation could be detrimental to sage-grouse; and additional conversion of native vegetation to cropland on private lands, particularly in MZ I, may undermine the ability to sustain sage-grouse on surrounding Federal lands.

Few studies have been published since 2015 regarding renewable energy and transmission lines. Although these studies corroborated previous research, the effects of power lines on sage-grouse are still unclear. Some of these gaps may be addressed by the long-term before-after-control-impact 
research in Nevada and a study under review from research on sage-grouse response to transmission lines at a wind-energy facility in Wyoming specifically addressing effects of power lines on sage-grouse. Additionally, the scope and scale of wind development research results are not yet sufficient to predict effects with desired certainty. Research examining the effects of nonrenewable energy development, primarily oil and gas, reported findings consistent with previous work. Energy development negatively affects lek attendance as well density increases, resulting in potential failure of population recruitment on leks within $6.4 \mathrm{~km}$ of development. A 1- to 4-year time lag in population response to development was consistently reported, similar to previous research. In Wyoming, current management restrictions on well density and well proximity to leks may only be sufficient for limiting population declines to current rates but not for reversing long-term population declines (Green and others, 2017). Recent research also is consistent with past findings that indicate implementation of certain mitigation techniques or design features for oil and gas operations may be beneficial in reducing, but not eliminating, adverse effects to sage-grouse. Lastly, this new research identifies that not all seasonal habitats can be protected by lek-based and nesting season restrictions.

Consistent with previous research, negative responses by sage-grouse to ex-urban development, well pads and roads, and human disturbance have been demonstrated by this recent work. These effects are intensified in highly fragmented habitats with low sagebrush landscape cover. Examination of connectivity between sage-grouse populations was modeled for multiple discrete anthropogenic features. The effects of these features on sage-grouse connectivity could not be separated from the presence of poor habitat, lek philopatry, or both, but this research emphasized the importance of connectivity between populations for the conservation of genetic diversity (see the following "Population Estimation and Genetics" section). The importance of private lands in maintaining connectivity across the entire range of sage-grouse could be examined further, particularly in areas with large amounts of private land holdings or high levels of habitat fragmentation.

\section{Overarching Findings and Implications}

Most of the literature reviewed on this topic corroborated the result of past findings and provided increased confidence in those results. Several studies reported quantitative properties that may be useful for consideration in future management activities.

- Modeling efforts indicate that strategies currently being implemented by local, State, and Federal land managers for oil and gas development may be successful at limiting sage-grouse population declines, but the conservation measures are not expected to reverse the declines where active oil and gas operations are present. Energy development within 1.61 to $4.83 \mathrm{~km}$, but outside of core areas has negative effects on sagegrouse leks within core areas, which may be a consid- eration for future development and conservation planning in Wyoming, as well as near other locations across the range with active energy development.

- The scope and scale of research regarding renewable energy development and transmission lines is not yet sufficient to understand the effects of these activities on sage-grouse with any certainty. Long-term projects in central Nevada and southern Wyoming may soon provide additional information on sage-grouse response to these features.

- Winter habitats outside of core areas support core area sage-grouse populations, and sage-grouse may use those habitats for a longer period than is identified by current regulatory restrictions in Wyoming.

- Maintaining private lands in native sagebrush or other permanent cover is important for sustaining sagegrouse populations in Washington and MZ I. Conservation Reserve Program lands in eastern Washington may be crucial for maintaining and improving connectivity for sage-grouse between the extremely fragmented sagebrush communities. In MZ I, conversion of private lands to cropland may undermine the ability to sustain sage-grouse on surrounding Federal lands.

- Genetic analyses emphasize the importance of maintaining connectivity between populations to ensure genetic diversity and distribution. New genetic information also provides insight to the size of local and regional populations needed to ensure genetic conservation.

\section{Diffuse Activities}

Several activities are broadly distributed across sagegrouse habitats and may impact sage-grouse population distribution or abundance, thus these can be considered diffuse activities. For many of these activities, there is limited knowledge or understanding of potential direct or indirect effects on sage-grouse. For purposes of this review, grazing, predators and predator control, sage-grouse hunting, wild horses and burros, fences, recreation, and noise were considered as diffuse activities.

Livestock grazing has long been considered a contributor to sage-grouse population declines, yet studies demonstrating a link between grazing and population trends are lacking (Knick and others, 2011). Grazing by domestic livestock can potentially improve or degrade sagebrush habitats depending upon grazing intensity and season of use (Connelly and Braun, 1997; Beck and Mitchell, 2000; Crawford and others, 2004; Boyd and others, 2014). Historically, improper grazing by livestock (that is, type and season of use that results in a vegetation phase at risk or departure from reference conditions) 
led to a decrease in native perennial grasses and forbs and effectively reduced abundance of fine fuels in some parts of the sage-grouse range (Miller and others, 2011). As such, improper livestock grazing management has been implicated in population declines of sage-grouse because reductions in vegetative cover, particularly grass cover, may negatively affect sage-grouse habitats and reproductive success (Gregg and others, 1994; Gregg and Crawford, 2009). Because information that links population dynamics of sage-grouse directly (that is, either correlative or through experiments) to how grazing is managed across the sagebrush landscape has not been available, the effects of livestock on sage-grouse populations are uncertain.

Predation of sage-grouse happens during all life stages (that is, egg, chick, juvenile, yearling, and adult) and is a major factor limiting recruitment for all grouse species (Bergerud, 1988). Sage-grouse are not a primary source of food for any one predator but are part of a suite of small-statured prey in the sagebrush biome that also includes rodents, rabbits, and hares (Schroeder and others, 1999; Hagen, 2011). Predation is most impactful to sage-grouse in the prerecruitment phases of the life cycle (that is, eggs and chicks) and for lekking males (Hagen, 2011). Females face the greatest risk of predation during the breeding season (Davis and others, 2014). A wide variety of species have been documented for predation and nest depredation of sage-grouse (Baxter and others, 2007; Coates and others, 2008; Coates and Delehanty, 2010; Hagen, 2011; Lockyer and others, 2013). Predation has been hypothesized to be an important limiting factor for sage-grouse, particularly in areas with poor habitat conditions or where predator abundance is high (Gregg and others, 1994; Aldridge and Brigham, 2001; Schroeder and Baydack, 2001; Coates and others, 2008; Lockyer and others, 2013). For example, one study indicated that nest predation by ravens was substantially higher for nests with relatively less shrub cover (Coates and Delehanty, 2010).

Hunting, as a direct removal of individual sage-grouse from populations, has the potential to be additive to natural mortality rates. In the threat assessment in the 2015 listing decision, the USFWS did not view regulated hunting as an important threat to the species but described the need for continued vigilance by State wildlife agencies to monitor population trends and adjust seasons if needed (U.S. Department of the Interior, 2015a). Removal of less than or equal to 10 percent of the autumn population from hunting was recommended by Connelly and others (2000). Harvest rates near 10 percent were compensatory and not additive based on an analysis of 18 years of band recovery data in Colorado (Sedinger and others, 2010). State wildlife agencies have taken a conservative approach to sage-grouse hunting in recent years consistent with these recommendations, including shortened seasons, reduced bag limits, and closures when populations decline below set management targets (Reese and Connelly 2011).

Wild horses (Equus caballus) and burros (E. asinus), like all large-bodied herbivores, can alter sagebrush ecosystem structure and composition and affect habitat quality for sagebrush obligate species (Beever and Aldridge, 2011). In the Conservation Objectives Team Report (U.S. Fish and Wildlife Service, 2013), wild horses and burros were considered a present and widespread threat in 10 of 29 populations in the western part of the sage-grouse range (MZs III-VI, fig. 1) but in only 1 of 15 populations in the eastern part (MZs I, II, and VII). Wild horses and burros were considered a persistent but localized threat in two populations in MZ II and in one population in MZ IV (U.S. Fish and Wildlife Service, 2013). Wild burros are not nearly as numerous as wild horses in the sagebrush biome; however, the tendency of burros to use lowelevation habitats throughout the year may increase their overlap with sage-grouse habitats (Beever and Aldridge, 2011).

Fences to control livestock and manage grazing can contribute to collision related mortality of sage-grouse, particularly when on flat terrain close to leks (Scott, 1942; Stevens and others, 2012). Collision probability is affected by distance to leks, fence attributes, terrain ruggedness index, and fence density and fence markers can be effective in substantially reducing fence collision risk by sage-grouse (Stevens and others, 2011, 2012).

Recreational activities (off-highway vehicle use, snowmobiling, mountain biking, hiking, camping, hunting [addressed separately], and fishing) can have both direct and indirect effects on sagebrush ecosystems and sage-grouse (Chambers and others, 2017a). Recreation was considered a threat in 9 of 15 populations in the eastern range and 19 of 29 populations in the western range in the Conservation Objectives Team Report (U.S. Fish and Wildlife Service, 2013).

Anthropogenic noise disrupts sage-grouse breeding behaviors (Blickley and Patricelli, 2012), increases stress levels (Blickley and others, 2012b), and decreases lek attendance (Blickley and others, 2012a). Consequently, management recommendations were developed based on these studies to limit anthropogenic noise sources to less than $10 \mathrm{~A}$-weighted decimals (dBA) above ambient noise (that is, noise in the absence of anthropogenic activities, typically less than or equal to $20 \mathrm{dBA}$ ) in breeding, nesting, and brood-reading habitats in addition to simple protections around leks (Patricelli and others, 2013).

\section{Findings}

Research on diffuse activities published since 2015 mostly focused on four sub-topics, including (1) grazing; (2) predation; (3) hunting; and (4) other diffuse activities. Findings of publications addressing these sub-topics are summarized below.

\section{Grazing}

Three of the papers reviewed evaluated how grazing may affect sage-grouse populations using correlative and retrospective studies. Annual counts of male sage-grouse from 743 leks in Wyoming during 2004-2014 were used to model sagegrouse population trends in response to grazing timing and 
intensity of grazing level across a gradient of vegetation productivity (Monroe and others, 2017). This was the first assessment to evaluate grazing effects on large-scale sage-grouse population dynamics. Monroe and others (2017) developed a relative index of grazing level for each allotment and year as the ratio of the reported livestock use relative to the maximum use authorized by BLM. They also classified grazing timing as the percentage of the relative grazing index that happened before the annual peak in vegetation productivity. When analyzed at broad scales in Wyoming, grazing may have both positive and negative effects on sage-grouse population trends, depending on grazing timing and level of the relative grazing index (Monroe and others, 2017). At high grazing levels, sage-grouse populations declined when grazing occurred early (before the peak in vegetation productivity) and increased when grazing occurred later. This may reflect the sensitivity of some grasses to grazing during their critical spring growing period, whereas when the same grasses are grazed later, after most of their growth is completed, these grasses may experience fewer negative effects. Grazing later in the growing season also may stimulate the additional growth of grasses and forbs if livestock remove standing dead vegetation or reduce shrub cover. At low grazing levels, however, the effects of grazing were minimal and did not vary with the timing of when grazing occurred; however, effects of grazing can depend on local vegetation productivity. In moister sites with greater vegetation productivity, grazing at intermediate levels was preferable to grazing later in the season or at higher grazing levels early in the season. In sites with high vegetation productivity, grazing early in the growing season at intermediate grazing levels may allow adequate time for plant regrowth and result in greater production than if grazing occurs later.

One study in central Montana evaluated how grazing strategies affected sage-grouse nesting habitat quality. Nest survival, evaluated at 501 nests between 2011 and 2016, was slightly higher on ranches using rotational compared to traditional grazing, but 95 percent credible intervals overlapped (Smith and others, 2017a). Results did not support the hypothesis that rotational grazing systems or rest from grazing increases nest success in the study area. Grazing treatments resulted in small differences in vegetation, and live- and senesced-grass height and litter cover were higher on ranches using rotational compared to traditional grazing, but effect sizes were small compared to annual variation, whereas visual obstruction was higher on rested compared to grazed lands. The authors suggest that grazing management likely has a minor effect on nest survival compared to factors such as weather and predators, and that observed nest survival rates are unlikely to be limiting population growth in the study area (Smith and others, 2017a). Most vegetation metrics on grazed lands were within one standard deviation of values on longterm idle lands, suggesting that vegetation similar to that on idle lands is likely abundant on grazed lands. Smith and others (2017a) suggest a variety of grazing management strategies can provide adequate habitat quality for nesting sage-grouse but urge caution in extrapolating results to other areas because of different precipitation regimes.

Lek counts were used as the primary metric in a post hoc analysis to evaluate effects of long-term ( 25 years) grazing at three ranches in northeastern Utah and southwestern Wyoming (Dahlgren and others, 2015). One ranch implemented smallacreage sagebrush treatments designed to reduce shrub cover and increase herbaceous understory within a high-intensity rotational grazing program. Sage-grouse lek counts at that study site increased relative to surrounding populations, and were sustained for nearly 15 years, before they matched nontreated population trends and population levels. The authors hypothesized that sagebrush treatments, coupled with rest-rotation grazing, increased the amount of grass and created additional forb availability and subsequent sage-grouse population increases (Dahlgren and others, 2015). However, they cautioned that the return to reduced population levels may have been caused by overtreatment and loss of important wintering habitat.

Grazing also can have indirect effects on sage-grouse and their habitats. For instance, managing grazing to maintain soil and hydrologic functioning and capacity of native perennial herbaceous species, especially perennial grasses, should help native plants to compete effectively with invasive plant species (Chambers and others, 2017b). Also, the presence of livestock in sage-grouse breeding areas in southern Idaho may affect sage-grouse nest success (Coates and others, 2016b), given ravens have been identified as major nest predators of sage-grouse (Coates and Delehanty, 2010; Dinkins and others, 2016a). The odds of raven occurrence in southern Idaho increased 45.8 percent in areas where livestock were present (Coates and others, 2016b).

\section{Predation}

One study documented the relation of ravens with livestock, showing both increased likelihood of the presence of ravens when livestock are also present and the association of ravens to infrastructure that support livestock, most notably water troughs (Coates and others, 2016b). Another study supported the previous finding (Dinkins and others, 2014) that sage-grouse hens avoid areas with higher predator densities (Mabray and Conover, 2015). After heavy raven control effort, raven populations declined approximately 10 percent in the year control was implemented (Peebles and Conover, 2016). Three other papers examined some aspect of sage-grouse response to predator removal activities: improved nest success in areas with raven removal but no improvement in areas with coyote removal (Dinkins and others, 2016a); increased movement rates and distances and larger home ranges for sage-grouse in areas where active coyote control was implemented (Orning and Young, 2016); and a correlation showing a positive relation between male lek counts in areas with raven control relative to areas without raven control (Peebles and others, 2017). 


\section{Hunting}

The effects of harvest timing and duration were examined using published seasonal survival estimates of juvenile and adult sage-grouse from Nevada (Blomberg, 2015). To explore if adjusting seasons to later in the year would lead to increases or decreases in sage-grouse populations, models were developed that examined over-winter survival and subsequent year reproductive success. Moving harvest to later in the season negatively affected survival and subsequent recruitment in a population model. This paper did not directly evaluate whether hunting is additive or compensatory, rather it suggested that in either scenario potential impacts to sage-grouse will be lessened by having seasons before or concurrent with peaks in natural mortality that may happen in early fall.

Another study challenged the validity of the equations used by Blomberg (2015) and explored the extent to which individual sage-grouse heterogeneity in survival and recruitment rates influences harvest effects on populations (Caudill and others, 2017). The assumption that individuals with lower rates of survival or recruitment are more susceptible to harvest, and thus have a compensatory effect from hunting, compared to individuals with higher rates of survival or recruitment being more susceptible to harvest, thus causing a depensatory or super-additive effect on populations from hunting, was examined in a model. Data on vital rates collected from Parker Mountain, Utah, from 1998 to 2010, where support exists for higher survival rates among sage-grouse hens that successfully nest and raise a brood relative to hens that do not, were used in the model (Caudill and others, 2017). Individual heterogeneity in survival and recruitment existed in sage-grouse, and the authors concluded that a conservative approach to harvest was appropriate and that short, 1- to 2 -week, delays in opening of sage-grouse hunting seasons may be prudent to allow successful hens to disperse from brood concentration areas.

A statistical population reconstruction model was developed to describe a novel approach to incorporating age-atharvest data from sage-grouse in Oregon (Clawson and others, 2017). No new insight to harvest effects on sage-grouse was provided in this study, but it does underscore the value of harvest data for modeling sage-grouse populations. Though the paper only examined Oregon sage-grouse harvest, these methods could be applied anywhere wing returns are collected for harvested sage-grouse to construct similar population models and used for assessing trends of hunted sage-grouse populations.

In a review paper of threat factors potentially attributable to sage-grouse declines, there was little support for the hypothesis that hunting of sage-grouse was responsible for long-term declines in sage-grouse distribution or abundance (Conover and Roberts, 2016). This summary paper did not bring any new information into consideration regarding harvest effects on sage-grouse populations.

\section{Other Diffuse Activities (Wild Horses and Burros, Fences, Recreation, and Noise)}

The influence of wild horses and burros on habitat management was considered in the context of resistance and resilience of sagebrush ecosystems (Chambers and others, 2016; Chambers and others, 2017a). However, no new information was presented on the effects of wild horses and burros on sage-grouse. Similarly other publications provided a review of known effects, but no new information was presented.

In southwestern Wyoming, fence markers substantially reduced collisions by sage-grouse, but collision rates did not vary significantly among marker types (that is, white, white with reflective tape, and yellow; Van Lanen and others, 2017). Fences with wooden posts had the lowest collision probabilities, followed by fences further from leks. Fences constructed in areas with vegetation of similar height as the fence also experienced reduced collision risk. The study found only a slightly elevated collision probability when compared to high and moderate risk areas from an existing and more generalized, range-wide model (Stevens and others, 2013).

Two recent studies on energy development did not produce new information on the effects of noise on sage-grouse (Smith and Dwyer, 2016; Green and others, 2017). They do provide a review of potential energy and noise effects (Smith and Dwyer, 2016) and mention noise as a possible mechanism influencing the interaction of energy development and sage-grouse population dynamics (Green and others, 2017).

\section{Potential Management Implications}

The relation between livestock grazing and sage-grouse population performance is difficult to determine given the diversity of ecological habitat conditions required by sagegrouse; high variability in climate and interannual precipitation; and the diversity of grazing types, seasons, and use. Benefits to sage-grouse from alternative grazing regimes designed to increase nest or brood survival have been minimal, or did not persist long term (Dahlgren and others, 2017; Smith and others, 2017a), although the authors identified the need for further study. A long-term experimental study is currently underway in Idaho. Estimates of timing and intensity of grazing recently have been shown to correlate with sage-grouse population trends in Wyoming (Monroe and others, 2017). These results suggest that modifications to grazing levels and season of use could attenuate declines or, in some cases, stabilize otherwise declining sage-grouse populations, though these responses vary depending on the productivity of the ecological sites. Indirect effects from livestock grazing on sage-grouse could also arise through increased predation from higher raven densities associated with areas of grazing activity (Coates and others, 2016b). Reducing livestock use near leks during nesting and brood rearing periods may reduce this effect (Coates and others, 2016b). 
Grazing can play an important role, both positively and negatively in promoting resistance and resilience within rangeland settings, particularly with respect to nonnative annual grasses (Chambers and others, 2017b). Grazing regimes within sage-grouse priority habitats could be designed to enhance ecological resistance and resilience. Grazing also can have detrimental, neutral, or positive effects on sage-grouse habitats across life stages, and population-level responses can arise, depending on grazing intensity and timing relative to vegetation phenology and productivity (Monroe and others, 2017). New information provides additional tools for managers to consider in conjunction with vegetation productivity and phenology when determining season of use or grazing intensity in important sage-grouse habitats. The generality of these results should be tested, ideally using replicated experiments to evaluate the effects of different grazing "treatments" on sage-grouse demographic rates (survival, reproductive effort, and population growth rates) and resource selection across life stages.

The lack of a definitive, well-designed experiment to examine long-term sage-grouse population responses to predator control remains. Newly published papers do not change the current understanding that although predation can be limiting sage-grouse populations in areas with over-abundant predator numbers or degraded habitats, predator control efforts are controversial, costly, and only provide limited and shortterm efficacy (Dinkins and others, 2016a; Orning and Young, 2016; Peebles and Conover, 2016; Peebles and others, 2017). The association of ravens and livestock and livestock infrastructure and the concomitant increased likelihood of ravens around leks indicate that limiting grazing activities in breeding habitats during nesting and brood-rearing periods may reduce predation on nests and broods (Coates and others, 2016b). This recommendation may be most appropriate for small or poorly performing populations of sage-grouse where ravens may be a limiting factor on population performance. However, these findings were from one location in southern Idaho, and it is not known whether similar relations between cattle and ravens are present more universally, so it may be useful to repeat this study in other parts of the range before broadly extrapolating these results. Raven control may be effective for limiting increases in smaller raven populations; when applied under such conditions, raven control potentially could benefit sage-grouse populations that are small or limited by habitat quantity or quality issues and have abundant raven populations (Peebles and Conover, 2016). During active raven control, lek counts increased, providing additional, though correlative, support for the potential population-level benefits of raven control for sage-grouse (Peebles and others, 2017). Additional support for raven control as a potential mechanism to increase sage-grouse nest success was found, though it was also noted that management of raven subsidies is most likely to generate long-term changes in raven numbers as raven control is likely to only produce short-term benefits for sage-grouse (Dinkins and others, 2016a). Predator removal activities can also have unintended consequences, such as apparent increases in movement-related activities of sage-grouse (Orning and Young, 2016), though the characterization of movement behaviors in this analysis did not consider other potential explanatory ecological or environmental factors.

None of the studies examining sage-grouse hunting implicated current application or timing of hunting seasons as plausible causes for sage-grouse declines. Refinements to the current structure, duration, and timing of hunting seasons used by State wildlife agencies may minimize potential noncompensatory effects to sage-grouse populations, but newly published recommendations are contradictory in their management recommendations for timing of hunting seasons (Blomberg, 2015; Caudill and others, 2017). These recent papers suggest that sage-grouse hunting season structures can be further refined based on locally available data to adjust timing of seasons so that harvest takes place before major mortality periods and to reduce harvest of successful brood hens.

There is still limited information regarding the effects of wild horses and burros and recreational activities on sagegrouse, and no new information on noise effects has been introduced in the literature. A singular study on fences confirms existing science showing risks of sage-grouse collisions was substantial near leks, and the risk declined as distance from leks increased (Van Lanen and others, 2017). Use of wooden posts or otherwise marking fences where collision risk is high may be appropriate.

\section{Overarching Findings and Implications}

- Livestock grazing can have detrimental, neutral, or positive effects on sage-grouse habitats with population-level effects, and the directionality of impact is dependent on grazing intensity and timing relative to vegetation phenology and productivity. A variety of locally appropriate range management strategies may be compatible with supporting sage-grouse populations.

- Predation can be limiting sage-grouse populations in areas with over-abundant predator numbers or degraded habitats. However, studies of predator control efforts are limited, and publications since 2015 point to the potential short-term application of predator control in small, declining populations. In the long term, reduced subsidies may be necessary to generate long-term changes in raven numbers as raven control is likely to only produce short-term benefits for sagegrouse.

- Refinements to the current hunting seasons used by State wildlife agencies may minimize potential noncompensatory effects to sage-grouse populations, but none of the studies implicated current application of hunting seasons and timings as a plausible cause for sage-grouse declines. 
- No new insights into the effects of wild horses and burros, fence collision, recreational activity, or noise on sage-grouse have been published.

\section{Fire and Invasive Species}

Fire is an infrequent yet natural driver of native sagebrush and grassland community dynamics in western North America; however, increasing wildfire size and frequency in sage-grouse habitats are major threats to sage-grouse populations, especially in the Great Basin (that is, MZ III, V and majority of MZ IV, fig. 1) and other western parts of their range (Miller and others, 2011; U.S. Fish and Wildlife Service, 2013; U.S. Department of the Interior, 2015b). Historically, fire was estimated to have happened every few decades in cooler, moist areas to hundreds of years in warmer, drier areas in the Great Basin (Baker, 2011; Miller and others, 2011), but with the invasion of cheatgrass and other nonnative annual grasses, the fire return interval is now as short as every 3 to 5 years in previously invaded and burned areas (Whisenant, 1990; D'Antonio and Vitousek, 1992). Because sagebrush may require decades to reestablish after burning, conversion of sagebrush shrubland and steppe to nonnative grasslands is facilitated by more frequent fires and the rapid reestablishment of invasive annual grasses (Burkhardt and Tisdale, 1976; Miller and Rose, 1999; Baker, 2006, 2011).

Past studies have provided extensive information about postfire response and recovery of vegetation in the sagebrush ecosystem (for example, Nelle and others, 2000; Wrobleski and Kauffman, 2003; Beck and others, 2009) and documented the negative effects of increasing fire frequency on sagegrouse habitats, including loss of shrub cover and potential conversion to annual grasslands (Nelle and others, 2000). Sage-grouse population trends and lek persistence also can be negatively affected by wildfire (Connelly and others, 2000a; Blomberg and others, 2012; Hess and Beck 2012).

The resilience and resistance of sagebrush ecosystems to altered fire regimes and expansion of nonnative plants vary along an environmental gradient generally dictated by soils, topography, and precipitation (Chambers and others, 2007, 2014a, 2014b). Low elevation sites typically support warm, dry sagebrush communities and higher elevations more cool, moist sagebrush communities. Fire regimes and recovery rates of sagebrush ecosystems after fire also vary along this environmental gradient. In general, lower elevations historically experienced very infrequent fires, whereas fires were more frequent at higher elevations (Miller and Rose, 1999; Baker, 2011). Sage-grouse habitats have declined at lower elevation sites as a result of increased invasive annual grasses, decreased native perennial bunchgrasses, and more frequent fires (Chambers and others, 2007, 2014a, 2014b; Davies and others, 2011).

Resilience after fire (that is, faster recovery rates) and resistance to invasion by nonnative annual grasses typically are higher in areas with a greater abundance of perennial native grasses and forbs, especially in high elevation, cool, moist areas, compared to low elevation, warm, dry areas (Chambers and others, 2007, 2014a, 2014b). Mountain big sagebrush (A.t. vaseyana) communities tend to exhibit higher resilience to wildfire and often exhibit an increase in forb cover after burning relative to Wyoming big sagebrush (A. t. wyomingensis) communities (Wrobleski and Kauffman, 2003). Because of loss of sagebrush cover after wildfire and long recovery times for sagebrush (for example, Shinneman and McIlroy, 2016), recent wildfires have been associated with negative sage-grouse population trends (see review in Connelly and others, 2000a) and increased lek abandonment (Hess and Beck, 2012). Wildfire (Nelle and others, 2000) and prescribed fire (Rhodes and others, 2010) have negatively affected sage-grouse habitats.

Scenario modeling can be useful for identifying potential vulnerabilities of sage-grouse habitats under different climate scenarios to help inform management decisions. Empirically derived relations between species occurrences, climate variability, and wildfire have been used to model the potential future distributions of species and ecological communities under projected climate scenarios. For example, studies indicated the potential for an overall retraction of sagebrush area in response to the climate scenarios evaluated (Schlaepfer and others, 2015; Still and Richardson, 2015) and from interactions between climate and invasive species (Bradley, 2010). Scenario models also indicated the potential for an increased probability of very large wildfires happening in parts of the sage-grouse range (Stavros and others, 2014; Barbero and others, 2015).

\section{Findings}

Research on fire and invasive species published since 2015 primarily focused on four sub-topics, including (1) multiscale fire effects on habitat; (2) effects of wildfire on habitat selection and demographics; (3) resilience and resistance concepts for wildfire and invasive species; and (4) predictive habitat modeling based on fire, invasive species, and climate projections. Findings of publications addressing these subtopics are summarized below.

\section{Multiscale Fire Effects on Habitat}

Information on fire size, total annual area burned, fire season, and fire rotation was summarized at multiple scales and by vegetation community for a 30 -year period (19842013) to evaluate threats to sage-grouse habitats (Brooks and others, 2015). During that 30-year period, approximately 11 percent of sagebrush (10.3 million ha) burned across the sage-grouse range. More than 80 percent of the burned area (8.37 million ha) was in the four western sage-grouse management zones (MZs III-VI, fig. 1). Increased fire size and frequency of recurrent fire, in conjunction with longer fire seasons, characterized the Snake River Plain (MZ IV) and the Columbia Basin (MZ VI) management zones. In contrast, approximately 1.9 million ha burned in the three eastern 
sage-grouse management zones (MZs I, II, VII), much of which happened in grasslands and with far less recurrent fire area compared to the western management zones. In the east, fire area and fire season length, but not fire size, increased during the 30-year period in the Great Plains (MZ I) and the Wyoming Basin (MZ II) management zones. Threats from wildfire vary by management zone and vegetation type across the range of sage-grouse. These results are consistent with previous range-wide studies demonstrating the greater vulnerability to the interaction between fire and occurrence of nonnative annual grasses in western sage-grouse management zones but also suggest fire may be an increasing threat in eastern management zones. At more local scales, information regarding the short- and long-term effects of both prescribed and wildfire on sage-grouse habitat is scarce, particularly for mesic high-elevation mountain big sagebrush communities (Davis and Crawford, 2015). Postfire recovery is highly variable and depends on prefire conditions and fire behavior. In mountain big sagebrush communities with low invasive annual grass cover, early postfire (less than 11 years after fire) herbaceous cover increased or was similar to nearby unburned areas (Davis and Crawford, 2015; Bates and others, 2017). These studies identified a short-term increase in forb cover, followed by increases of perennial bunchgrasses, and low potential for invasion by nonnative annual grasses. Conversely, prefire condition of warm, dry sagebrush communities is an important consideration in managing sage-grouse habitats using fire (Bates and others, 2017). In central Oregon, an experimental study of vegetation response to burning ( 1 and 17 years postfire) was completed in a cool, dry Wyoming big sagebrush community with overall low invasive annual grass cover and no recent domestic livestock grazing (that is, a community with limited anthropogenic influence pretreatment) (Ellsworth and others, 2016). Natural recovery led to increased cover of perennial bunchgrasses relative to unburned control plots, regenerating sagebrush, and similar (but highly variable) prefire and 17-year postfire forb cover, indicating high resiliency to a prescribed fire for this relatively intact Wyoming sagebrush community. In localized sites with high prefire cover of cheatgrass, a corresponding postfire release of cheatgrass was observed, and control sites had marginally lower cheatgrass than treatment sites ( $p$-value $=0.07$; Ellsworth and others, 2016).

\section{Effects of Wildfire on Habitat Selection and Demographics}

Direct effects of wildfire on sage-grouse habitat selection, vital rates, or population trends have received fairly sparse attention until recently (Coates and others, 2016e). Several comprehensive studies of nesting, brood rearing, and lek attendance have greatly enhanced the spatial and temporal scope of the information on the response of sage-grouse to fire in the Great Basin (Coates and others, 2015, 2016e) and in Wyoming (Smith and Beck, 2017).
Both wildfire and prescribed fire negatively affected sagegrouse population trends as measured by lek counts. In Wyoming, sage-grouse populations declined for at least 11 years in response to sagebrush treatments by both prescribed fire and wildfire (Smith and Beck, 2017). Similarly, from 1984 to 2013 , the rate of sage-grouse population growth was reduced by 2.1 percent as burned area increased within $5 \mathrm{~km}$ of leks across the Great Basin (Coates and others, 2016e). If current trends in area burned continue, a 43 percent reduction in sagegrouse population size is projected within the Great Basin by 2044 (Coates and others, 2016e).

In fire-impacted landscapes, sage-grouse were more likely to nest under nonsagebrush cover with commensurate reduction in nest success (Lockyer and others, 2015; Coates and others, 2017a). Sage-grouse disproportionately used areas within burn perimeters with relatively high sagebrush and other vegetative cover (for example, greater perennial forb cover), and nests under sagebrush had a higher success rate compared to other cover types (Coates and others, 2017a). The negative effects of fire persisted for at least 17 years. Within these burned areas in the Virginia Mountains, Nevada, cheatgrass cover increased compared to nearby unburned sites, and sage-grouse avoided areas with high cheatgrass cover (Coates and others, 2017a).

\section{Resilience and Resistance Concepts for Wildfire and Invasive Species}

The concepts of ecological resilience to wildfire and other disturbances and resistance to invasive species have been used to develop a broad-scale, science-based approach for rapid risk assessments for wildfire and annual invasive grasses, to determine appropriate management strategies, and to prioritize resources for the conservation of sage-grouse and their habitats across the sagebrush biome (Chambers and others, 2016, $2017 \mathrm{a}, \mathrm{b})$. The approach uses soil temperature and moisture regimes as biophysical indicators of ecosystem resilience and resistance (Maestas and others, 2016). Ecological resilience and resistance of sagebrush communities, as defined by low risk of conversion to invasive annual grasses and potential for recovery after wildfire and other disturbances, generally increase along an elevational gradient corresponding to soil moisture and temperature with corresponding changes to vegetation communities (that is, Wyoming big sagebrush in low, warm, dry sites and mountain big and low sagebrush in high, cool, moist sites). Generalized resilience and resistance categories across sagebrush communities were used to create a risk-based framework to identify potential focal areas for sagebrush and sage-grouse habitat management actions (Chambers and others, 2016, 2017b).

Complementing the resilience and resistance literature in the sagebrush biome is a three-part restoration handbook (Pyke and others, 2015a, b, 2017) that provides a synthetic overview of sagebrush ecosystem plant communities and restoration strategies after disturbance based on resilience and resistance 
concepts. This restoration handbook provides a detailed approach for determining restoration needs. Other recently developed field guides also provide information for application of resistance and resilience concepts (Miller and others, 2014, 2015). Additional guidance on plants to use for postfire restoration was synthesized from published information and highlighted postfire rehabilitation and invasive plant control methods that can have detrimental effects on native plant species required by sage-grouse (Dumroese and others, 2015).

\section{Predictive Habitat Modeling Based on Fire, Invasive Species, and Climate Projections}

The potential for cheatgrass invasion was evaluated for climate scenarios in the Great Basin and Snake River Plain (Boyte and others, 2016; the Snake River Plain is located southern Idaho). Empirically derived models of the relations between contemporary cover of cheatgrass in shrub-steppe systems were developed (Boyte and Wylie, 2016) and used to evaluate potential for change in cheatgrass cover under multiple climate scenarios. For the climate scenarios evaluated, the models indicated that percent cover of cheatgrass could remain stable over more than 80 percent of the study area, whereas approximately 18 percent was vulnerable to increasing cheatgrass cover. Topography and weather variation were key contributors to geographic variation in patterns among Priority Areas for Conservation (PACs; U.S. Fish and Wildlife Service, 2013).

The potential interactions between climate and land management scenarios were evaluated in sage-grouse habitat in eastern Oregon (Creutzberg and others, 2015). The potential for wildfire occurrence increased, and vulnerability to invasive annual grasses in warm dry shrub-steppe remained high for all climate scenarios evaluated. The analyses indicated the potential for effective control of conifer expansion but had little effect on annual grass abundance. The potential consequences for sage-grouse habitat were less consistent with time, indicating the potential value of conifer removal, though climate played a larger role in influencing sage-grouse habitats.

\section{Potential Management Implications}

Wildfire activity has increased in parts of the sage-grouse range in recent decades, and historical fire regimes have been altered for many sagebrush landscapes, especially where invasive nonnative annual grasses contribute to more frequent fire. In Wyoming sagebrush communities highly altered by invasive annual grasses and grazing, negative effects of wildfire have been documented for crucial sage-grouse habitat characteristics, although effects vary depending a number of factors including elevation, sagebrush community type, relative resistance and resilience to fire, time since fire, and prefire site conditions (Nelle and others, 2000; Davis and others, 2015, Bates and others, 2017). Negative effects of wildfire on sagegrouse are largely consistent with previous studies and include altered habitat selection, vital rates, and population trends
(Coates and others, 2015, 2016e, 2017a; Smith and Beck, 2017). The findings here support existing concerns and planning efforts to reduce the threat of wildfire to sage-grouse (see U.S. Fish and Wildlife Service, 2013; U.S. Department of the Interior, 2015a). Despite evidence of resilience and resistance in comparatively intact cool, dry sagebrush communities (Ellsworth and others, 2016), cheatgrass release in localized sites and higher mean cheatgrass measures in treated compared to control sites within the study area provide additional support for recommendations of fire suppression in dry sites to prevent the spread of annual invasive grasses and loss of habitats for sage-grouse (Knick, 1999; Murphy and others, 2013). Tools to prioritize fire suppression efforts, inform strategic placement of fuels treatments that address high fire frequencies, and improve techniques to restore/rehabilitate fire-affected habitats and limit cheatgrass invasion, are essential to maintaining healthy sage-grouse populations.

Several new broad-scale tools have been developed that can help prioritize management actions and inform budget processes. The growing body of literature on resilience and resistance provides both range-wide and regional maps, sagegrouse habitat resilience and resistance matrices, sage-grouse wildfire risk assessment, and a table of management strategies for the three resilience and resistance categories (Maestas and others, 2016; Chambers and others, 2016, 2017a, b). These products offer a foundation for prioritizing sage-grouse conservation resources and determining effective restoration and management strategies. A specific strength of these publications is that they assist prioritization of management actions to improve sage-grouse habitat conditions across the entire sagebrush biome. At the same time, the maps and risk-based frameworks are generalized because of the broadscale mapping efforts, and locally derived information may be necessary to refine recommended management strategies at the implementation level. Other research offers guidance for restoration strategies at the local level (for example, field offices) that correlates well with the concepts of resilience and resistance developed at broader regional levels (Miller and others, 2014, 2015; Pyke and others, 2015a, b, 2017). Information on specific treatment effectiveness within resilience and resistance categories can be combined with broad-scale findings reviewed here to further refine and inform restoration strategies.

In addition to the resilience and resistance studies, projections of change in species distributions under climate scenarios can be helpful for understanding coarse-scale trends and may provide guidance in the placement of monitoring to track changes through time and inform implementation of adaptive management strategies. Projections of wildfire behavior and nonnative annual grass invasion further reinforce the potential importance of large-scale implementation of monitoring and management tools and the development of additional tools and strategies to address the negative effects of wildland fire and invasive species on sage-grouse. It is important to note that modeled future projections have considerable variability and uncertainty based on methods, climate scenarios used in the 
analyses, and scales of inference. Future projections often do not account for natural ecological and disturbance processes, such as pathogens, that may further influence species shifts across a landscape in response to climate variability. Managers should understand these caveats when using future projections in project planning, siting, and design.

\section{Overarching Findings and Implications}

- Science since 2015 supports previous qualitative assessments highlighting the potential large-scale threats from changing wildland fire frequency and size. Negative effects of wildfire on sage-grouse include changes in available habitat, reductions in multiple vital rates, and declining population trends.

- The concepts of resilience after wildfire and resistance to invasion by nonnative annual grasses have been mapped across the sagebrush biome using links to soil temperature and moisture regimes. These maps create a framework that can be used in developing effective restoration and management strategies and can help prioritize application of sage-grouse conservation resources across the entire sagebrush biome.

- Potential long-term changes in wildfire behavior and nonnative annual grass invasion because of warming trends reinforce the potential importance of large-scale monitoring strategies and development of tools to effectively target fire suppression, place fuel breaks, and treat nonnative annual grass invasions.

\section{Restoration Effectiveness}

Restoration, rehabilitation, and reclamation activities intended to improve sage-grouse habitat conditions, recover areas degraded or lost to a variety of disturbances, or prevent further degradation or loss are increasingly important for maintaining sage-grouse populations (Pyke 2011). Generally, these activities are implemented through a variety of vegetation treatments designed to alleviate threats to habitat (for example, anthropogenic disturbances and wildfire) or deficiencies in one or more sage-grouse habitat objectives (Stiver and others, 2015). Most treatments are planned and implemented at local site scales (for example, reductions in shrub overstory cover intended to restore desired perennial grasses and forbs; fuel break networks to protect habitats from wildfire); however, less is understood about the aggregate effects of multiple treatments and effects across large landscapes.

Placement and implementation of habitat treatments to affect the maximum benefit for sage-grouse habitat use, behavior, demography, and, ultimately, population size, while also providing for other land uses, are challenges for land management practitioners in a multiple-use landscape. Multiple seasonal habitat requirements, as well as large intact sagebrush landscapes necessary to support sage-grouse populations, exacerbate this challenge (Connelly and others, 2000b). The use of range-wide or regional approaches has been identified as an effective method to determine when and where to place treatments and aid in prioritizing limited resources (Meinke and others, 2009; Pyke, 2011; Chambers and others, 2014c).

Restoring sagebrush communities can be difficult, costly, and slow. Consequently, scientists and managers can benefit from tools to help determine resource allocation for restoration and conservation actions. Applied research has provided insights for improving the design and techniques used to implement treatments to recover sagebrush vegetation (Stevens, 2004; Arkle and others, 2014; Knutson and others, 2014; McIver and Brunson, 2014; Ott and others, 2016) and reduce the multiple threats to sage-grouse (U.S. Fish and Wildlife Service, 2013; U.S. Department of the Interior, 2015a). For example, conifer expansion can have population-level effects, resulting in decreased activity at leks where conifer canopy cover exceeds 4 percent (Baruch-Murdo and others, 2013). However, very little information was available before 2015 on sage-grouse occupancy of treated areas after conifer removal, and the extent to which demographic rates were influenced. Similarly, although sagebrush manipulation treatments in certain habitats can increase understory vegetation, the direct benefits to sage-grouse are not well documented (Beck and others, 2012). Although applied research has provided useful guidance to help plan and implement treatments, questions remain concerning where treatments should be sited within a landscape to best achieve desired conditions in the long term as well as their effects on habitat selection and demography.

\section{Findings}

Research on restoration effectiveness published since 2015 primarily focused on three sub-topics, including (1) conifer removal; (2) sagebrush manipulation and understory restoration; and (3) decision support for restoration. Findings of publications addressing these sub-topics are summarized below.

\section{Conifer Removal}

Recent studies confirm previous knowledge that sagegrouse generally avoid conifers and prefer habitat farther from conifers during the breeding season (Doherty and others, 2016; Freese and others, 2016; Cook and others, 2017) and when establishing nests (Severson and others, 2017a). Also, sage-grouse are at a substantially greater risk of mortality when moving through conifer woodlands, and that risk varies among sage-grouse age classes and juveniles have increased mortality relative to yearlings and adults (Prochazka and others, 2017).

To reduce the threat of conifer expansion, many efforts have been made to remove conifers from sagebrush communities across the western United States. Previous results have shown that effectiveness of treatments to remove conifers and establish functional sage-grouse habitat may depend on several factors including (1) methods (for example, prescribed 
fire, mastication, chaining, and cutting); (2) pretreatment vegetation condition and composition; (3) woodland phase (I, II, or III; Miller and others, 2005); and (4) ecological site potential. For example, mechanical control of conifers in phase I and II woodlands have been found to maintain or quickly recover the major characteristics of shrub-steppe habitat when compared to prescribed fire (Boyd and others, 2017).

\section{Treatment Effects on Demographics}

Sage-grouse respond favorably to conifer removal treatments. In Oregon, annual female and nest survival increased in a conifer treatment (primarily hand cutting) area relative to an untreated control (Severson and others, 2017d). Using stochastic simulations of population estimates and published demographics, a 25-percent increase was estimated in the population growth rate in the treatment area relative to the control area.

In Utah, probability of individual nest and brood success was higher closer to conifer removal areas and decreased farther from mechanical conifer removal treatments (Sandford and others, 2017). This study did not examine the treatment effect on demographic rates of other life stages (for example, brood survival) that could affect overall growth rates. While encouraging, this study took place in an area with previously limited available habitat (Cook and others, 2017) reducing the certainty that conifer removal will convey similar demographic benefits in other areas where suitable nesting and brood-rearing habitats are not limited.

\section{Treatment Effects on Habitat Selection Patterns}

Sage-grouse selected for nest sites and brood-rearing habitats closer to conifer removal treatments in an area otherwise degraded by conifer encroachment and isolated by surrounding agriculture and other unsuitable habitat (Sandford and others, 2017). In a before-after-control-impact design experiment, the relative probability of nesting in sites where conifers were removed increased by 22 percent annually, and females were 43 percent more likely to nest within $1 \mathrm{~km}$ of treatments (Severson, and others, 2017c). Females avoided nesting where conifer cover exceeded 3 percent within a 2-square-kilometer area around nests. However, in an observational study of mechanical conifer treatments in Utah, no difference was found in sage-grouse use of treated or untreated reference sites (Cook and others, 2017). However, this study lacked pretreatment data, and landscape cover of agriculture land use had the greatest effect on whether treatment areas were used by sage-grouse. Mechanical conifer removal, done primarily for sage-grouse, influenced abundance of sagebrush-associated songbirds (Brewer's sparrow, green-tailed towhee [Pipilo chlorurus], and vesper sparrow [Pooecetes gramineus]), and populations of these species more than doubled after conifer removal (Holmes and others, 2017).

\section{Treatment Effects on Habitat}

Treatment effects of conifer removal (hand cutting) on a suite of vegetation characteristics known to be important for sage-grouse nesting (for example, percent cover of forbs, grasses, and shrubs, and species richness of forbs and shrubs) were examined in one study (Severson, and others, 2017b). Previous findings were supported in that conifer removal resulted in increases in perennial grass cover and tall forb cover, but shrub cover did not increase. A meta-analysis found that the response of perennial and annual forbs consumed by sage-grouse in the Great Basin varied by treatment method and site potential (Bates and others, 2017). For example, annual forbs favored by sage-grouse benefited most from prescribed fire treatments with smaller increases after mechanical and fuel reduction treatments. Perennial forb response did not vary by treatment (fire or mechanical) but was influenced by site potential. These results challenge the assumption that woodland control results in increased cover, density, and yield of all herbaceous life forms (Miller and others, 2005), and those outcomes likely being influenced by other factors such as site potential, soil moisture, and resistance to invasive annual grasses.

\section{Sagebrush Manipulation and Understory Restoration}

Mechanical and chemical treatments and prescribed fire have been used to reduce sagebrush woody fuels and restore the composition of understory herbaceous vegetation (that is, forbs and perennial grasses) that are important as cover and food for sage-grouse. However, the herbaceous vegetation response after treatment is variable and dependent on interactions between treatment type and environmental characteristics including the site's resilience to disturbance and resistance to invasive species (Chambers and others, 2017b).

Understory vegetation (either forbs or perennial grass species) generally increased after sagebrush manipulation, but the response of sage-grouse to treatments varied, perhaps due in part to site-specific ecological variability (Dahlgren and others, 2015; Baxter and others, 2017; Smith and Beck, 2017). Two of these studies found potential benefits of sagebrush manipulation treatments (Dahlgren and others, 2015; Baxter and others, 2017). A long-term study in northern Utah and southwest Wyoming found some evidence that small-scale sagebrush removal can benefit sage-grouse at mid to high elevations ( $>2,000 \mathrm{~m}$; Dahlgren and others, 2015). In areas with sagebrush treatments, sage-grouse lek counts increased within short but not long periods relative to surrounding populations (Dahlgren and others, 2015). However, the results of this study were confounded by overlapping sagebrush control treatments (Lawson aerator, discing, chain harrow, Tebuthiuron, and prescribed fire) and grazing regimes on the study sites. In Utah, mechanical treatments in dense ( $>40$ percent) mountain big sagebrush seemeded to increase availability of brood-rearing 
habitat, which was found to be limiting in the area (Baxter and others, 2017). However, the value of implementing this type of treatment depends on sagebrush density, whether broodrearing habitat is scarce, and if the proposed treatment areas have the potential to provide habitat for nesting and winter concentration areas.

Conversely, prescribed fire and mechanical treatments, but not chemical treatments, had negative or neutral effects on sage-grouse populations for at least 11 years after treatment in Wyoming (Smith and Beck, 2017). At lower elevations in Wyoming, wildfire had a persistent and negative effect on population change for sage-grouse, and a positive population response after herbicide treatments may have resulted from herbaceous cover increases where sagebrush cover remained intact. Wyoming big sagebrush dominated this study area, which differed from the two study sites in Utah where a positive effect of sagebrush manipulation to sage-grouse was detected in higher elevation sagebrush communities (Dahlgren and others, 2015; Baxter and others, 2017).

\section{Decision Support for Restoration Actions}

Decision support tools have been developed that help managers select landscapes where strategically placed restoration treatments are most likely to benefit sage-grouse populations in the long term (Pyke and others, 2015b; Chambers and others, 2017a). These tools help managers determine landscape objectives, and identify and prioritize landscapes where restoration projects might minimize risk and maximize effectiveness. Information on ecosystem resilience and resistance, species habitats, and predominant threats have been combined through a geospatial process to develop a science framework that can be used at the mid-scale to prioritize areas for management (Chambers and others, 2017a). Prioritized areas and management strategies can be refined by managers and stakeholders at the local scale based on higher resolution data and local knowledge. The overarching goal of the science framework is to promote ecosystem resilience to disturbance and resistance to invasive species (Chambers and others, 2017a; see also Chambers and others, 2016) by incorporating the likely response of an area to disturbance or stress because of threats or management actions, the capacity of an area to support target species or resources, and the predominant threats. Important information for determining the suitability of an area for a treatment and the most appropriate treatments includes (1) ecological site descriptions and relative resilience to disturbance and resistance to invasive annual grasses; (2) ecological dynamics of the ecological sites and, where possible, their restoration pathways; and (3) actions that could increase ecosystem functioning and habitat connectivity (see Miller and others, 2014, 2015; and Pyke and others, 2015a, b 2017, for detailed descriptions of this process).

At the broad-scale, important factors to consider when siting treatments include the extent of areas with suitable sagebrush cover (Pyke and others, 2015b; Chambers and others, 2017a), and the size of current sage-grouse populations
(Doherty and others, 2016, Coates and others, 2017b, c). For example, an examination of sage-grouse populations in the Great Basin demonstrated the potential benefits to long-term sage-grouse population trends if fire suppression activities were more effective and focused in areas with larger populations and greater sagebrush landscape cover (Coates and others, 2015, 2016e). The amount of landscape cover of sagebrush by itself also can help determine long-term management strategies owing to the strong link between sage-grouse and sagebrush. In high cover sites, priorities may include maintenance of ecosystem connectivity and function, whereas preventing conversion to undesirable alternative states may be most appropriate in moderate cover sites, and in low cover sites active restoration of ecological communities to meet desired conditions is a management focus (Chambers and others, 2017a).

Maintaining connectivity among PACs through restoration activities or conservation of existing sagebrush communities at important "pinch points," where movements are constrained, is an important component of an overall sage-grouse management strategy (Crist and others, 2017). Maintenance or restoration of habitat quality within corridors is important to limit exposure to risk (for example, from predators), and because sage-grouse use these sites as resting and refueling areas (Newton and others, 2017). Optimization models that identify important areas for conifer removal along movement pathways could help decision makers anticipate whether future actions are most likely to benefit connectivity (Reinhardt and others, 2017).

Research on the stability of sagebrush ecosystems to long-term weather patterns highlighted potential future restoration challenges. Less soil water will likely be available for plants (Palmquist and others, 2016a), and the expected number of dry days are expected to increase range wide, especially in the eastern and northern parts of the sage-grouse range (Palmquist and others, 2016b). These forecasted changes in long-term temperature and precipitation patterns may be important considerations when setting restoration objectives, as well as siting and prioritizing treatments, particularly in areas with low resilience and resistance (Chambers and others, 2017b; Creutzburg and others, 2015). For example, climate forecasts in southeast Oregon indicate that conifer removal treatments are more likely to be successful in slowing woodland expansion and maintaining sage-grouse habitats than management actions that are targeted at controlling exotic grass invasion, given currently available management tools (Creutzburg and others, 2015).

Using treatments (for example, conifer removal) to address habitat threats may not have much benefit to sagegrouse unless restoration siting is optimized (Farzan and others, 2015; Reinhardt and others, 2017). For example, sagegrouse breeding population abundance and mesic resource proximity are strongly correlated (Donnelly and others, 2016), so implementation of siting optimization strategies to conserve habitat near this limiting resource may have additional benefits for sage-grouse. 


\section{Potential Management Implications}

An overarching objective of habitat restoration for any species is to first identify desired conditions and then incorporate environmental and population variability that influence these requirements. Sage-grouse habitat requirements and fidelity to selected habitats have been well described across many parts of their range, and new decision tools have been developed that use both landscape- and site-scale environmental variability to guide restoration strategies (see the "Multiscale Habitat Suitability and Mapping Tools" section). Restoration science has focused extensively on where to conduct effective treatments and has identified a set of major threats, such as conifer encroachment, that can be treated to offset environmental trajectories that negatively impact sagegrouse landscapes.

Conceptual frameworks, restoration handbooks, and research findings that have regional implications provide new important guidance for managers to understand how and where to most effectively implement sagebrush habitat restoration treatments. Resilience and resistance concepts are used extensively to develop spatially explicit strategic approaches for conservation actions to address persistent ecosystem threats such as invasive annual grasses and wildfire (Chambers and others, 2016, 2017a, b). Likewise, resilience and resistance concepts are a foundation for a set of recent restoration handbooks and field guides for sagebrush ecosystems that guide restoration decisions at the site and landscape level (Miller and others, 2014, 2015; Pyke and others, 2015a, b, 2017).

Recent broad-scale studies provide new information for consideration for restoration planning. Maintaining connectivity among PACs (Crist and others, 2017; Reinhardt and others, 2017) by restoring or conserving sagebrush communities at important "pinch points" where sage-grouse population movements are constrained may prevent the negative effects of population isolation. In the Great Basin, focusing fire suppression activities in areas with greater sagebrush cover and larger populations is a strategy that could benefit sagegrouse conservation efforts (Coates and others, 2016e, 2017b, c), although this does not diminish the threat of wildfire to sage-grouse habitat in general. Future climate conditions also are an important consideration when identifying the best treatment tools and locations (Creutzburg and others, 2015; Balzotti and others, 2016). Finally, targeting conservation efforts in areas near mesic resources may have elevated benefits because sage-grouse breeding population abundance and mesic resource proximity are strongly correlated (Donnelly and others, 2015).

Despite recent advances in determining how and where to treat, there remain critical gaps in the overall understanding of how restoration affects sage-grouse demography. Treatments may address threats to sagebrush habitat, but it is rare to have information regarding how and to what degree those restoration treatments help sage-grouse populations. Although it seems likely that restoring sagebrush habitat usually benefits sage-grouse, it is unknown if certain project areas act as ecological traps (Battin, 2004). In addition to effectiveness monitoring, the application of new techniques to map the importance of habitat features to population dynamics could help elucidate the contributions of treatments to sage-grouse population demographic rates (Heinrichs and others, 2017b; Kane and others, 2017).

\section{Overarching Findings and Implications}

- At the site level, studies published from 2015 to 2017 were generally consistent with existing knowledge but provided some new information that could guide management. However, the scope of inference of these findings appears to be limited to specific sagebrush communities, locations, and treatment types.

- Conifer removal had potential benefits for sage-grouse with increased female survival and nest and brood success following treatment. Benefits of treatments may be higher in areas where suitable habitats are limiting. Treatment method and site potential are important considerations as they can influence the posttreatment vegetation characteristics, including the availability of perennial and annual forbs consumed by sage-grouse.

- Sage-grouse brood-rearing habitat availability increased and populations appeared to benefit over the short-term from sagebrush manipulation treatments. However, these benefits have only been demonstrated in Utah and are most likely limited to areas with high sagebrush cover at higher elevations and in mountain big sagebrush communities. Type of treatment was important to the overall effectiveness of sagebrush removal or thinning treatments. Sage-grouse populations did not benefit from, or were negatively affected by, prescribed fire and mechanical sagebrush removal treatments in Wyoming big sagebrush. However, areas treated with chemical herbicide appeared to provide a benefit, perhaps because some sagebrush cover remained intact and herbaceous cover increased.

- Decision support tools have been developed that help managers identify and select landscapes where strategically placed restoration treatments will most likely have the greatest benefit for sage-grouse populations. These tools use ecosystem resilience to disturbance and resistance to nonnative annual grass invasion, sage-grouse habitat selection, and location of predominant threats to prioritize areas for future management actions at broad scales that can then be further refined at the local scale based on higher resolution data and local knowledge. 


\section{Population Estimation and Genetics}

Since the 1950s, biologists have worked to improve techniques for estimating the size of sage-grouse populations (Patterson, 1952). Estimating sage-grouse population trends in a consistent manner within population units and across the full species range has been a challenge for Federal and State wildlife agencies. However, substantial progress has been made in recent decades to collect and analyze population data to inform ongoing sage-grouse management (Braun, 1998; Reese and Bowyer, 2007; Garton and others, 2011).

Monitoring of sage-grouse populations depends on lek count surveys and estimation of other demographic properties, such as nest success and age specific survival rates. Lek surveys are often the only source used to estimate population trends largely because these data are fairly easy to collect and widely available (Fedy and Aldridge, 2011; Western Association of Fish and Wildlife Agencies, 2015). However, use of this data to accurately monitor populations entails accounting for sources of inaccuracy in counts, such as imperfect detection of individual sage-grouse, differences in lek visitation (Pollock and others, 2002), and the differentiation between population changes that arise from correlations with larger scale and stochastic environmental phenomena (for example, weather patterns; Fedy and Doherty, 2011) compared to those that are driven by local or regional habitat change or disturbances (Walker and others, 2007). Other important considerations for use of lek count data include imperfect detection of newly formed leks and nonrandom sampling of leks (Connelly and others, 2004).

Utilizing vital rate data (for example, survival and recruitment) and lek count data through the use of advanced methods such as integrated population models (Schaub and Abadi, 2011) can improve population estimates. In addition to providing better population trend estimates, output from these models can allow managers to assess which vital rates are most responsible for population changes and how changes happening at one spatial scale are related to those happening at another (Schaub and Abadi, 2011; Soranno and others, 2014). These approaches are fast becoming more common and accessible to managers across the range.

Use of applied genetic techniques to inform sage-grouse management has expanded rapidly. Before 2015, sage-grouse genetics were used to differentiate distinct sage-grouse populations (Oyler-McCance and others, 2005), which supported designation of the bi-State sage-grouse population at the southwestern edge of the species range as a distinct population segment under the Endangered Species Act (U.S. Department of the Interior, 2010).

\section{Findings}

Findings of research published since 2015 about sagegrouse population estimation and genetics are summarized below.

\section{Population Estimation}

Major advances in tools and techniques have improved estimates of sage-grouse population abundance and increased options for the detection of population change (positive and negative) across different spatial and temporal scales. The following studies represent substantial contributions that have advanced estimation of vital rates, integration of multiple data sources into population models, estimation of population sizes and boundaries, and identification of important scale-dependent changes to populations largely driven by environmental and anthropogenic factors.

Estimates of sage-grouse population sizes and trends rely heavily on lek count observations. Important new findings have led to the identification of sources of variation in lek counts so that changes in estimated population size reflect true changes in abundance and not errors in counting because of variable detection probabilities or lek attendance rates. At the level of the individual count, counts completed between 0.5 hour before sunrise to 1.5 hours after sunrise using standardized protocols detected 79 percent of sage-grouse on leks (Baumgardt and others, 2017). Fremgen and others (2016) found similarly high detection (range: 77 to 93 percent) of sage-grouse on leks during counts. Both studies support the use of lek count data as a reliable index of sage-grouse population size, and correction factors that account for undetected birds on leks because of variation in lighting conditions, vegetation composition and structure, and bird activity can be calculated to provide more precise estimates of actual population size. Additional support for the use of current lek count protocols to index sage-grouse population growth was provided by Monroe and others (2016), who also reported that the precision of population trend estimates was unaffected by survey timing (that is, counts completed within 30 minutes before and after sunrise compared to counts completed up to 1.5 hours after sunrise). Although lek attendance peaked within 30 minutes of sunrise, capitalizing on the full survey window allows more leks to be counted, which increases the precision of population estimates without introducing noteworthy statistical bias.

Although male sage-grouse generally exhibited strong affinity to the same lek on a daily basis, up to 33 percent of males have been shown to move between leks during the breeding season (Fremgen and others 2017). These types of movements previously have been shown to result in up to 40 percent of the variation in annual lek counts (Blomberg and others, 2013). Interlek movements were most probable during the early breeding season and at higher elevation leks. In contrast, the peak of the breeding season where lek attendance is highest (as demonstrated by Monroe and others, 2016) had the lowest likelihood of interlek movement (Fremgen and others 2017), which gave rise to the recommendation that counts should be completed during that period. Finally, models have been developed that can take advantage of repeated count data at leks during a survey year (as opposed to just using 
maximum counts) and account for variation in detection probability and missing data to produce more accurate population trend estimates (McCaffery and others, 2016).

Population models also require unbiased input data from different sources to generate reliable results, and recent research provides recommendations for the collection and use of these data. For example, age and gender structure can be estimated reliably from examination of primary flight feather shape (age) and length (gender) (Braun and Schroeder, 2015). Field studies of radio-marked sage-grouse also are essential for obtaining data on demographic vital rates, and a key assumption is that marking and monitoring do not introduce bias in observed vital rates. Importantly, care should be taken during nest monitoring to avoid flushing incubating females (particularly younger individuals or females nesting in poor habitat) to reduce observer-induced bias in nest survival estimates (Gibson and others, 2015). Harvest data in States where sage-grouse are hunted are available for use in modeling population abundance. These data can be particularly useful when other sources of data such as lek count or other data are lacking. Such an exercise was completed recently using sagegrouse harvest data from Oregon, which helped demonstrate cyclical population trends and high variability in recruitment (Clawson and others, 2017).

Statistical models that incorporate data from multiple spatial scales have been particularly powerful in determining factors influencing the trajectory and shape of sage-grouse population trends. Lek count data is particularly well suited for use in these spatially hierarchical models since leks are somewhat fixed on the landscape and can be clustered together in spatially nested groups (Coates and others, 2017c). For example, population viability at nested spatial scales related to management designations in Wyoming (core and noncore areas, and State working group areas) has been modeled using long-term ( 23 years) lek count data (Edmunds and others 2017). At small scales (core area), neighboring populations could show different trends because of localized effects that would otherwise be masked by large-scale (working group area) trends affected by broad-scale factors (climate patterns) that can drive population cycles. Understanding how, when, and where sage-grouse exhibit population cycles also has been improved through use of new statistical models applied to time series lek count data. Substantial variation across space and through time were found using wavelet and spectral analysis to examine regional differences in population cycling across the range of sage-grouse (Row and Fedy, 2017). Populations in the core range - Great Basin and Wyoming Basin-exhibited the most consistent cycling but with smaller differences between population highs and lows. Population trends for marginal populations decoupled from expected cycles, and large-scale spatial synchrony among populations weakened as cycles weakened. Length between cycles for most populations also decreased with time and may be a precursor for the loss of population cycling.

Contemporary population ecology also has witnessed an explosion of applications that can be used to integrate multiple data types (for example, occupancy, counts, and vital rates) and better identify specific factors driving population growth. An analysis of long-term (12-year) demographic vital rates using a female-based life-cycle model determined that postfledging survival for females had the greatest effect on annual rates of population change (Dahlgren and others 2016a).

Estimates derived from female-based vital rates matched those derived from male-based lek counts, and factors affecting survival of females that produce offspring may be more readily addressed through management actions. For example, translocated females need to survive more than 2 years post release to produce offspring at rates comparable to source populations (Duvuvuei and others 2017). Together, these studies point to survival of breeding females as an important determinant of variation in population growth. The accuracy of sage-grouse population trends can be greatly improved within an integrated population modeling framework by incorporating data that describe demographic processes within the life cycle of sagegrouse (vital rates) and the outcome of those processes on abundance (lek counts) (McCaffery and others, 2016; Coates and others, 2018).

Integrated population models seek to partition process from sampling variance, which allows the use of information across different data sources (that is, lek counts and vital rates) to refine overall estimates of population size at different spatial scales (Arnold and others, 2018). A generalized integrated population model was developed for sage-grouse to help improve population growth estimates from lek counts where demographic data may be sparse (McCaffery and Lukacs, 2016). Further advancements in estimation and adjustment in sharing of information within an integrated population model framework were developed in areas where demographic data were available (Coates and others, 2018). Such modeling advances also allowed for separation of interannual variation in population growth driven by changes in precipitation from environmental factors affecting populations at local spatial scales (Coates and others, 2018), and also helped to identify effects on a specific life stage (for example, nesting) limiting population growth. Use of individual-based population simulation models also may provide insights into demographic rates that are influential for changing population trajectories (Heinrich and others, 2017a, 2018).

A framework for adaptive management based on population changes within Nevada and California has been built using results, and concepts from many of these studies (Coates and others, 2017c) and can serve as an early warning system for detecting population declines at different spatial scales. This study improves on past research and adaptive management processes by identifying spatial boundaries that defined hierarchical levels of organization based on lek clusters to provide biologically relevant scale of inference for management application. Additionally, this framework provides a technique to separate broad-scale causes of population declines (for example, weather) from the effects of local level disturbances and habitat change, and is readily updatable using new lek count data as it is collected. Lastly, the framework provides a 
quantitative method for assessing effectiveness of restoration projects on sage-grouse populations.

\section{Genetics}

The use of advanced molecular techniques has enabled identification of unique, genetically structured populations that support species differentiation in sage-grouse, as in the case of the Gunnison sage-grouse (Fike and others, 2015; OylerMcCance and others, 2015b), and designation of distinct population segments for management, as in the case of the bi-State Distinct Population Segment (Oyler-McCance and others, 2015a). There also is new empirical evidence on the mechanisms governing the exchange of genetic information among populations. For example, affinity to breeding leks can inherently restrict gene flow and provide a mechanism for maintaining localized genetic structure (Cross and others, 2016, 2017; Jahner and others, 2016). However, increased habitat suitability, especially during nesting and winter periods, and decreased anthropogenic effects on the landscapes between individual and groups of leks can facilitate higher rates of gene flow that are important for population persistence (Cross and others, 2017; Jahner, 2016; Row and others, 2015, 2016).

Exchange of genetic material among populations also can be achieved through the long distance movement of just a few breeding individuals (Cross and others, 2016, 2017). Dispersal of a few individuals from centrally located populations to outlying populations may be the key component for genetic connectivity, given that reductions in the size and dispersal rates of centrally located source populations may have the largest negative effect on regional genetic differentiation (Row and others, 2015). New statistical models also allow better identification of the effects of landscape resistance (for example, low habitat quality) and account for effects of geographic distance among populations (Row and others, 2017).

Spatially explicit identification of areas with low genetic diversity can help better target subpopulations for translocations designed to promote genetic diversity (Jahner and others, 2016; Cross and others, 2016). In geographically isolated populations in Washington, landscape resistance models at a fine scale (30-m resolution) that incorporated genetic data and resistances of landscape features (for example, roads, land cover, and transmission lines) developed using local expert knowledge performed better than both coarse (100-m resolution) and fine scale expert-only models of landscape resistance (Shirk and others, 2015). This integrated landscape integrity model also predicted that Conservation Reserve Program and dryland wheat production lands may be less of a barrier to sage-grouse movement than previously understood. Major advances in the identification of populations at risk were made by mapping genetically structured populations in Wyoming and then coupling that with demographic information on population trends (Fedy and others, 2017). New genetic techniques provided strong evidence that PACs in Montana aligned well with genetically identified subpopulations (Cross and others, 2017).

\section{Potential Management Implications}

Major advances in the understanding of how sightability and attendance rates affect sage-grouse detectability during lek counts have helped resolve many previous criticisms of these data and support the continued use of lek counts as part of population monitoring protocols across the species range. These advances have included the development of correction factors (Baumgardt and others, 2017; Fremgen and others, 2016, 2017), establishment of the importance of survey timing (Monroe and others, 2016), and development of methods for the use of multiple counts (McCaffery and others, 2016). These will lead to more accurate and precise estimates of sage-grouse abundance. However, development of new lek count strategies and databases to accommodate additional information may be necessary to take advantage of these new methods.

Contemporary and more advanced statistical models are well suited to take advantage of the hierarchical and longterm nature of sage-grouse lek count data. These analyses help identify the factors that influence population trends at different spatial scales relevant to management and identify spatiotemporal variability in cyclical population dynamics that sage-grouse commonly display (Coates and others, 2017c; Edmunds and others, 2017; Row and Fedy, 2017).

Integrated population models that leverage information from vital rates and lek counts can yield more refined estimates of sage-grouse abundance (McCaffery and others, 2016) and help identify differences between local and regional population trends (Coates and others, 2018). These types of models guide prescribed targeted management actions aimed at specific vital rates that can reverse adverse effects among different unique populations. Building upon these collective concepts and results, in Nevada and northeast California, Coates and others (2017c) have provided a hierarchical approach and framework that identifies where and when sage-grouse populations at specific spatial scales significantly decline in a manner unexpected based on larger-scale population trends. This feature is especially important since sage-grouse population growth (particularly populations in more arid environments) tends to positively track periods of favorable resource availability (often correlated with precipitation). Thus, knowing whether local population declines are simply tracking larger scale patterns that are relatively unmanageable compared to those responding negatively to a more manageable and localized disturbance is key for informing effective adaptive management. Work is currently underway to expand the work of Coates and others (2017c) to develop a range-wide framework.

In addition to estimating numbers, population modeling also can inform conservation planning efforts by integrating changes in habitat with population responses. Integration of habitat selection, demographic information, movement, and behavior resulted in a framework that simulated population dynamics and habitat risks in Canada (Heinrichs and others, 2018). This modeling effort also identified areas of habitat restoration that were most likely to increase chick survival 
and nest success, key vital rates for sage-grouse. Although this research was done in Canada, where sage-grouse populations and their habitats are very small, the resulting modeling approach could be used across the species' entire range.

Given the substantial population declines and habitat losses sage-grouse have experienced across their range, it is important to understand the extent to which current populations are functionally connected through gene flow, and the environmental factors that may affect that connectivity. Advances in molecular techniques have allowed high-resolution determination of sage-grouse genetic structure at multiple spatial scales. This has been important for identifying distinct populations and species that warrant separate management (Fike and others, 2015; Oyler-McCance and others, 2015a). Perhaps more importantly, the integration of genetic structure data into advanced statistical models has enhanced the understanding of how movement of genetic material among populations is influenced by landscape context and configuration (Cross and others, 2017; Hanks and others, 2016; Jahner, 2016; Row and others, 2015, 2016, 2017). Going forward, information from studies that integrate relations between genetic structure and population performance can help facilitate adaptive management (Fedy and others, 2017). Models that reflect resistance to movement could help managers understand those landscape features that may impede the ability of individuals (or their genes) to move across the landscape. Recent work of Row and others (2015) provides mapping tools that can explicitly incorporate important corridors for genetic connectivity.

\section{Overarching Findings and Implications}

- Development of correction factors, understanding of the effects of survey timing on counts, and the use of multiple count surveys have improved techniques for completing sage-grouse lek count surveys and increased the accuracy and precision of sage-grouse population estimates. Agencies may need to revise lek count protocols or databases to incorporate new information and facilitate use of new analysis techniques.

- Large advances have improved methods to analyze sage-grouse population data, including the ability to develop nested hierarchical population estimates to target management and incorporate multiple vital rates via an integrated population modeling framework to understand the contribution of each rate to overall population trends.

- Advances in molecular techniques have improved mapping of sage-grouse genetic structure at multiple spatial scales and integration of this genetic structure data into advanced statistical models has enhanced the understanding of how movement of genetic material among populations is influenced by landscape context and configuration.

\section{References Cited}

Aldridge, C.L., and Boyce, M.S., 2007, Linking occurrence and fitness to persistence - A habitat-based approach for greater sage-grouse: Ecological Applications, v. 17, no. 2, p. 508-526. [Also available at https://doi.org/10.1890/051871.]

Aldridge, C.L., and Brigham, R.M., 2001, Nesting and reproductive activities of greater sage-grouse in a declining northern fringe population: The Condor, v. 103, no. 3, p. 537-543. [Also available at http://www.jstor.org/stable/1369825.]

Aldridge, C.L., Nielsen, S.E., Beyer, H.L., Boyce, M.S., Connelly, J.W., Knick, S.T., and Schroeder, M.A., 2008, Rangewide patterns of greater sage-grouse persistence: Diversity and Distributions, v. 14, no. 6, p. 983-994. [Also available at https://doi.org/10.1111/j.1472-4642.2008.00502.x.]

Arkle, R.S., Pilliod, D.S., Hanser, S.E., Brooks, M.L., Chambers, J.C., Grace, J.B., Knutson, K.C., Pyke, D.A., Welty, J.L., and Wirth, T.A., 2014, Quantifying restoration effectiveness using multi-scale habitat models-Implications for sage-grouse in the Great Basin: Ecosphere, v. 5, no. 3, p. 1-32. [Also available at https://doi.org/10.1890/ES1300278.1.]

Arnold, T.W., Clark, R.G., Koons, D.N., and Schaub, Michael, 2018, Integrated population models facilitate ecological understanding and improved management decisions: Journal of Wildlife Management, v. 82, p. 266-274, accessed January 5, 2018, at https://doi.org/10.1002/jwmg.21404.

Baker, W.L., 2006, Fire and restoration of sagebrush ecosystems: Wildlife Society Bulletin, v. 34, no. 1, p. 177185. [Also available at https://doi.org/10.2193/00917648(2006)34[177:FAROSE]2.0.CO;2.]

Baker, W.L., 2011, Pre-Euroamerican and recent fire in sagebrush ecosystems, in Knick, S.T., and Connelly, J.W., eds., Greater sage-grouse-Ecology and conservation of a landscape species and its habitats: Berkeley, Calif., University of California Press, Studies in Avian Biology, no. 38, p. 185-201.

Balzotti, C.S., Kitchen, S.G., and McCarthy, Clinton, 2016, Beyond the single species climate envelope-A multifaceted approach to mapping climate change vulnerability: Ecosphere, v. 7, no. 9, art. e01444, accessed December 2017 at https://doi.org/10.1002/ecs2.1444.

Barbero, R., Abatzoglou, J.T., Larkin, N.K., Kolden, C.A., and Stocks, B., 2015, Climate change presents increased potential for very large fires in the contiguous United States: International Journal of Wildland Fire, v. 24, no. 7, p. 892899. [Also available at https://doi.org/10.1071/WF15083.] 
Baruch-Mordo, Sharon, Evans, J.S., Severson, J.P., Naugle, D.E., Maestas, J.D., Kiesecker, J.M., Falkowski, M.J., Hagen, C.A., and Reese, K.P., 2013, Saving sage-grouse from the trees-A proactive solution to reducing a key threat to a candidate species: Biological Conservation, v. 167, p. 233-241. [Also available at https://doi. org/10.1016/j.biocon.2013.08.017.]

Bates, J.D., Davies, K.W., Hulet, April, Miller, R.F., and Roundy, Bruce, 2017, Sage grouse groceries-Forb response to piñon-juniper treatments: Rangeland Ecology \& Management, v. 70, no. 1, p. 106-115. [Also available at https://doi.org/10.1016/j.rama.2016.04.004.]

Battin, James, 2004, When good animals love bad habitats-Ecological traps and the conservation of animal populations: Conservation Biology, v. 18, no. 6, p. 14821491. [Also available at https://doi.org/10.1111/j.15231739.2004.00417.x.]

Baumgardt, J.A., Reese, K.P., Connelly, J.W., and Garton, E.O., 2017, Visibility bias for sage-grouse lek counts: Wildlife Society Bulletin, v. 41, no. 3, p. 461-470. [Also available at https://doi.org/10.1002/wsb.800.]

Baxter, J.J., Baxter, R.J., Dahlgren, D.K., and Larsen, R.T., 2017, Resource selection by greater sage-grouse reveals preference for mechanically-altered habitats: Rangeland Ecology and Management, v. 70, no. 4, p. 493-503. [Also available at https://doi.org/10.1016/j.rama.2017.01.007.]

Baxter, R.J., Bunnell, K.D., Flinders, J.T., and Mitchell, D.L., 2007, Impacts of predation on greater sage-grouse in Strawberry Valley, Utah: Transactions of the 72d North American Wildlife and Natural Resources Conference, p. 258-269. [Also available at https://wildlifemanagement.institute/sites/ default/files/2016-09/8-Impacts_of_Predation.pdf.]

Beck, J.L., Connelly, J.W., and Reese, K.P., 2009, Recovery of greater sage grouse habitat features in Wyoming big sagebrush following prescribed fire: Restoration Ecology, v. 17, no. 3, p. 393-403. [Also available at https://doi.org/10.1111/ j.1526-100X.2008.00380.x.]

Beck, J.L., Connelly, J.W., and Wambolt, C.L., 2012, Consequences of treating Wyoming big sagebrush to enhance wildlife habitats: Rangeland Ecology \& Management, v. 65, no. 5, p. 444-455. [Also available at https://doi.org/10.2111/ REM-D-10-00123.1.]

Beck, J.L., and Mitchell, D.L., 2000, Influences of livestock grazing on sage grouse habitat: Wildlife Society Bulletin, v. 28, no. 4, p. 993-1002. [Also available at https://www. jstor.org/stable/3783858.]
Becker, J.M., Tagestad, J.D., Duberstein, C.A., and Downs, J.L., 2009, Sage-grouse and wind energy - Biology, habits, and potential effects from development: Richland, Wash., Pacific Northwest National Laboratory, prepared for the U.S. Department of Energy under contract DE-AC0576RL01830, 35 p., accessed December 2017 at https://www. pnnl.gov/main/publications/external/technical_reports/ PNNL-18567.pdf.

Beever, E.A., and Aldridge, C.L., 2011, Influences of freeroaming equids on sagebrush ecosystems, with a focus on greater sage-grouse, in Knick, S.T., and Connelly, J.W., eds., Greater sage-grouse - Ecology and conservation of a landscape species and its habitats: Berkeley, Calif., University of California Press, Studies in Avian Biology, no. 38, p 273-290.

Bergerud, A.T., 1988, Mating systems in grouse, in Bergerud, A.T., and Gratson, M.W., eds., Adaptive strategies and population ecology of northern grouse-Volume I. Population studies: Minneapolis, Minn., University of Minnesota Press, p. 439-470.

Billings, W.D., 1994, Ecological impacts of cheatgrass and resultant fire on ecosystems in the Western Great Basin, in Monsen, S.B., and Ketchum, S.G., comps., ProceedingsEcology and management of annual rangelands: Ogden, Utah, U.S. Department of Agriculture, Forest Service, Intermountain Research Station, General Technical Report INT-GTR-313, p. 22-30. [Also available at https://www. fs.usda.gov/treesearch/pubs/31975.]

Blickley, J.L., Blackwood, Diane, and Patricelli, G.L., 2012a, Experimental evidence for the effects of chronic anthropogenic noise on greater sage-grouse at leks: Conservation Biology, v. 26, no. 3, p. 461-471. [Also available at https:// doi.org/10.1111/j.1523-1739.2012.01840.x.]

Blickley, J.L., and Patricelli, G.L., 2012, Potential acoustic masking of greater sage-grouse (Centrocercus urophasianus) display components by chronic industrial noise: Ornithological Monographs, no. 74, p. 23-35. [Also available at https://doi.org/10.1525/om.2012.74.1.23.]

Blickley, J.L., Word, K.R., Krakauer, A.H., Phillips, J.L., Sells, S.N., Taff, C.C., Wingfield, J.C., and Patricelli, G.L., 2012b, Experimental chronic noise is related to elevated fecal corticosteroid metabolites in lekking male greater sage-grouse (Centrocercus urophasianus): PLoS ONE, v. 7, no. 11, art. e50462. [Also available at https://doi.org/10.1371/journal.pone.0050462.]

Blomberg, E.J., 2015, The influence of harvest timing on greater sage-grouse survival-A cautionary perspective: Journal of Wildlife Management, v. 79, no. 5, p. 695-703. [Also available at https://doi.org/10.1002/jwmg.887.] 
Blomberg, E.J., Sedinger, J.S., Atamian, M.T., and Nonne, D.V., 2012, Characteristics of climate and landscape disturbance influence the dynamics of greater sage-grouse populations: Ecosphere, v. 3, no. 6, art. 55, p. 1-20. [Also available at https://doi.org/10.1890/ES11-00304.1.]

Blomberg, E.J., Sedinger, J.S., Nonne, D.V., and Atamian, M.T., 2013, Annual male lek attendance influences countbased population indices of greater sage-grouse: Journal of Wildlife Management, v. 77, no. 8, p. 1583-1592. [Also available at https://doi.org/10.1002/jwmg.615.]

Boyd, C.S., Beck, J.L., and Tanaka, J.A., 2014, Livestock grazing and sage-grouse habitat: impacts and opportunities: Journal of Rangeland Applications, V.1, p. 58-77. [Also available at https://journals.lib.uidaho.edu/index.php/jra/ article/view/17/44.]

Boyd, C.S., Kerby, J.D., Svejcar, T.J., Bates, J.D., Johnson, D.D., and Davies, K.W., 2017, The sage-grouse habitat mortgage - Effective conifer management in space and time: Rangeland Ecology \& Management, v. 70, no. 1, p. 141-148. [Also available at https://doi.org/10.1016/j. rama.2016.08.012.]

Boyte, S.P., and Wylie, B.K., 2016, Near-real-time cheatgrass percent cover in the Northern Great Basin, USA, 2015: Rangelands, v. 38, no. 5, p. 278-284. [Also available at https://doi.org/10.1016/j.rala.2016.08.002.]

Boyte, S.P., Wylie, B.K., and Major, D.J., 2016, Cheatgrass percent cover change-Comparing recent estimates to climate change-driven predictions in the Northern Great Basin: Rangeland Ecology \& Management, v. 69, no. 4, p. 265-279. [Also available at https://doi.org/10.1016/j. rama.2016.03.002.]

Braun, C.E., 1998. Sage grouse declines in western North America-What are the problems?: Proceedings of the Western Association of State Fish and Wildlife Agencies, v. 78, p. 139-156.

Braun, C.E., Baker, M.F., Eng, R.L., Gashwiler, J.S., and Schroeder, M.H., 1976, Conservation committee report on effects of alteration of sagebrush communities on the associated avifauna: The Wilson Bulletin, v. 88, no. 1, p. 165-171. [Also available at http://www.jstor.org/stable/4160730.]

Braun, C.E., and Schroeder, M.A., 2015, Age and sex identification from wings of sage-grouse: Wildlife Society Bulletin, v. 39, no. 1, p. 182-187. [Also available at https://doi. org/10.1002/wsb.517.]
Brooks, M.L., Matchett, J.R., Shinneman, D.J., and Coates, P.S., 2015, Fire patterns in the range of the greater sagegrouse, 1984-2013-Implications for conservation and management: U.S. Geological Survey Open-File Report 2015-1167, 66 p. [Also available at https://doi.org/10.3133/ ofr20151167.]

Bureau of Land Management, 2015a, Notice of availability of the record of decision and approved resource management plan amendments for the Great Basin Region Greater SageGrouse sub-regions of Idaho and Southwestern Montana; Nevada and Northeastern California; Oregon; and Utah: Bureau of Land Management, Federal Register, v. 80, no. 185 , p. 57633-57635.

Bureau of Land Management, 2015b, Notice of availability of the record of decision; and approved resource management plan amendments for the Rocky Mountain Region Greater Sage-Grouse sub-regions of Lewistown, North Dakota, northwest Colorado, and Wyoming; and approved resource management plans for Billings, Buffalo, Cody, HiLine, Miles City, Pompeys Pillar National Monument, South Dakota, and Worland: Federal Register, v. 80, no. 185, p. 57639-57641.

Burkhardt, J.W., and Tisdale, E.W., 1976, Causes of juniper invasion in southwestern Idaho: Ecology, v. 57, no. 3, p. 472-484. [Also available at https://doi. org/10.2307/1936432.]

Burnham, K.P., and Anderson, D.R., 2002, Model selection and multimodel inference-A practical information-theoretic approach (2d ed.): New York, Springer-Verlag New York, Inc., 488 p.

Carter, S.K., Manier, D.J., Arkle, R.S., Johnston, A.N., Phillips, S.L., Hanser, S.E., and Bowen, Z.H., 2018, Annotated bibliography of scientific research on greater sage-grouse published since January 2015: U.S. Geological Survey Open-File Report 2018-1008, 183 p, accessed February 2018 at https://doi.org/10.3133/ofr20181008. [Also available at https://apps.usgs.gov/gsgbib/index.php.]

Casazza, M.L., Coates, P.S., and Overton, C.T., 2011, Linking habitat selection and brood success in greater sage-grouse, in Sandercock, B.K., Martin, Kathy, and Segelbacher, Gernot, eds., Ecology, conservation, and management of grouse: Berkeley, Calif., University of California Press, Studies in Avian Biology, no. 39, p. 151-167.

Caudill, Danny, Guttery, M.R., Terhune, T.M., II, Martin, J.A., Caudill, Gretchen, Dahlgren, D.K., and Messmer, T.A., 2017, Individual heterogeneity and effects of harvest on greater sage-grouse populations: Journal of Wildlife Management, v. 81, no. 5, p. 754-765. [Also available at https:// doi.org/10.1002/jwmg.21241.] 
Chambers, J.C., Beck, J.L., Bradford, J.B., Bybee, Jard, Campbell, Steve, Carlson, John, Christiansen, T.J., Clause, K.J., Collins, Gail, Crist, M.R., Dinkins, J.B., Doherty, K.E., Edwards, Fred, Espinosa, Shawn, Griffin, K.A., Griffin, Paul, Haas, J.R., Hanser, S.E., Havlina, D.W., Henke, K.F., Hennig, J.D., Joyce, L.A., Kilkenny, F.F., Kulpa, S.M., Kurth, L.L., Maestas, J.D., Manning, Mary, Mayer, K.E., Mealor, B.A., McCarthy, Clinton, Pellant, Mike, Perea, M.A., Prentice, K.L., Pyke, D.A., Wiechman, L.A., and Wuenschel, Amarina, 2017a, Science framework for conservation and restoration of the sagebrush biome-Linking the Department of the Interior's Integrated Rangeland Fire Management Strategy to long-term strategic conservation actions - Part 1. Science basis and applications: U.S. Department of Agriculture, Forest Service, Rocky Mountain Research Station, General Technical Report RMRS-GTR-360, accessed November 9, 2017, at https:// www.fs.fed.us/rmrs/publications/science-frameworkconservation-and-restoration-sagebrush-biome-linkingdepartment.

Chambers, J.C., Beck, J.L., Campbell, Steve, Carlson, John, Christiansen, T.J., Clause, K.J., Dinkins, J.B., Doherty, K.E., Griffin, K.A., Havlina, D.W., Mayer, K.F., Hennig, J.D., Kurth, L.L., Maestas, J.D., Manning, Mary, Mealor, B.A., McCarthy, Clinton, Perea, M.A., and Pyke, D.A., 2016, Using resilience and resistance concepts to manage threats to sagebrush ecosystems, Gunnison sage-grouse, and greater sage-grouse in their eastern range-A strategic multi-scale approach: U.S. Department of Agriculture, Forest Service, Rocky Mountain Research Station, General Technical Report RMRS-GTR-356, accessed November 9, 2017, at https://www.fs.fed.us/rmrs/publications/using-resilience-and-resistance-concepts-manage-threats-sagebrushecosystems-gunnison.

Chambers, J.C., Bradley, B.A., Brown, C.A., D’Antonio, Carla, Germino, M.J., Grace, J.B., Hardegree, S.P., Miller, R.F., and Pyke, D.A., 2014a, Resilience to stress and disturbance, and resistance to Bromus tectorum L. invasion in the cold desert shrublands of western North America: Ecosystems, v. 17, no. 2, p. 360-375. [Also available at https://doi. org/10.1007/s10021-013-9725-5.]

Chambers, J.C., Maestas, J.D., Pyke, D.A., Boyd, C.S., Pellant, Mike, and Wuenschel, Amarina, 2017b, Using resilience and resistance concepts to manage persistent threats to sagebrush ecosystems and greater sage-grouse: Rangeland Ecology \& Management, v. 70, no. 2, p. 149-164. [Also available at https://doi.org/10.1016/j.rama.2016.08.005.]
Chambers, J.C., Miller, R.F., Board, D.I., Pyke, D.A., Roundy, B.A., Grace, J.B., Schupp, E.W., and Tausch, R.J., 2014b, Resilience and resistance of sagebrush ecosystems-Implications for state and transition models and management treatments: Rangeland Ecology \& Management, v. 67, no. 5, p. 440-454. [Also available at https://doi.org/10.2111/ REM-D-13-00074.1.]

Chambers, J.C., Pyke, D.A., Maestas, J.D., Pellant, Mike, Boyd, C.S., Campbell, S.B., Espinosa, Shawn, Havlina, D.W., Mayer, K.E., and Wuenschel, Amarina, 2014c, Using resistance and resilience concepts to reduce impacts of invasive annual grasses and altered fire regimes on the sagebrush ecosystem and greater sage-grouse-A strategic multi-scale approach: U.S. Department of Agriculture, Forest Service, Rocky Mountain Research Station, General Technical Report RMRS-GTR-326, 73 p. [Also available at https://www.fs.fed.us/rmrs/publications/using-resistanceand-resilience-concepts-reduce-impacts-invasive-annualgrasses-and.]

Chambers, J.C., Roundy, B.A., Blank, R.R., Meyer, S.E., and Whittaker, A., 2007, What makes Great Basin sagebrush ecosystems invasible by Bromus tectorum?: Ecological Monographs, v. 77, no. 1, p. 117-145. [Also available at https://doi.org/10.1890/05-1991.]

Clawson, M.V., Skalski, J.R., Lady, J.M., Hagen, C.A., Millspaugh, J.J., Budeau, David, and Severson, J.P., 2017, Performing statistical population reconstruction using program PopRecon 2.0: Wildlife Society Bulletin, v. 41, no. 3, p. 581-589. [Also available at https://doi.org/10.1002/ wsb.790.]

Coates, P.S., Andrle, K.M., Ziegler, P.T., and Casazza, M.L., 2016a, Monitoring and research on the Bi-State Distinct Population Segment of greater sage-grouse (Centrocercus urophasianus) in the Pine Nut Mountains, California and Nevada_-Study progress report, 2011-15: U.S. Geological Survey Open-File Report 2015-1222, 40 p., accessed December 2017 at https://doi.org/10.3133/ofr20151222.

Coates, P.S., Brussee, B.E., Howe, K.B., Gustafson, K.B., Casazza, M.L., and Delehanty, D.J., 2016b, Landscape characteristics and livestock presence influence common ravens - Relevance to greater sage-grouse conservation: Ecosphere, v. 7, no. 2, art. e01203, accessed December 2017 at https://doi.org/10.1002/ecs2.1203. 
Coates, P.S., Brussee, B.E., Ricca, M.A., Dudko, J.E., Prochazka, B.G., Espinosa, S.P., Casazza, M.L., and Delehanty, D.J., 2017a, Greater sage-grouse (Centrocercus urophasianus) nesting and brood-rearing microhabitat in Nevada and California - Spatial variation in selection and survival patterns: U.S. Geological Survey Open-File Report 2017-1087, 79 p., accessed December 2017 at https://doi. org/10.3133/ofr20171087.

Coates, P.S., Casazza, M.L., Blomberg, E.J., Gardner, S.C., Espinosa, S.P., Yee, J.L., Wiechman, Lief, and Halstead, B.J., 2013, Evaluating greater sage-grouse seasonal space use relative to leks - Implications for surface use designations in sagebrush ecosystems: Journal of Wildlife Management, v. 77, no. 8, p. 1598-1609. [Also available at https:// doi.org/10.1002/jwmg.618.]

Coates, P.S.; Casazza, M.L.; Brussee B.E.; Ricca, M.A.; Gustafson, K.B.; Overton, C.T.; Sanchez-Chopitea, Erika; Kroger, Travis; Mauch, Kimberly; Niell, L.E.; Howe, Kristy; Gardner, S.C.; Espinosa, S.P.; and Delehanty, D.J., 2014, Spatially explicit modeling of greater sagegrouse (Centrocercus urophasianus) habitat in Nevada and northeastern California-A decision-support tool for management: U.S. Geological Survey Open-File Report 2014-1163, 84 p., accessed December 2017, https://doi. org/10.3133/ofr20141163.

Coates, P.S., Casazza, M.L., Brussee, B.E., Ricca, M.A., Gustafson, K.B., Sanchez-Chopitea, Erika, Mauch, Kimberly, Niell, L.E., Gardner, S.C., Espinosa, S.P., and Delehanty, D.J., 2016c, Spatially explicit modeling of annual and seasonal habitat for greater sage-grouse (Centrocercus urophasianus) in Nevada and Northeastern California-An updated decision-support tool for management: U.S. Geological Survey Open-File Report 2016-1080, 160 p., accessed December 2017 at https://doi.org/10.3133/ ofr20161080.

Coates, P.S., Casazza, M.L., Ricca, M.A., Brussee, B.E., Blomberg, E.J., Gustafson, K.B., Overton, C.T., Davis, D.M., Niell, L.E., Espinosa, S.P., Gardner, S.C., and Delehanty, D.J., 2016d, Integrating spatially explicit indices of abundance and habitat quality-An applied example for greater sage-grouse management: Journal of Applied Ecology, v. 53, no. 1, p. 83-95. [Also available at https://doi. org/10.1111/1365-2664.12558.]

Coates, P.S., Connelly, J.W., and Delehanty, D.J., 2008, Predators of greater sage-grouse nests identified by video monitoring: Journal of Field Ornithology, v. 79, no. 4, p. 421-428. [Also available at https://doi.org/10.1111/ j.1557-9263.2008.00189.x.]
Coates, P.S., and Delehanty, D.J., 2010, Nest predation of greater sage-grouse in relation to microhabitat factors and predators: Journal of Wildlife Management, v. 74, no. 2, p. 240-248. [Also available at http://www.jstor.org/stable/27760445.]

Coates, P.S., Prochazka, B.G., Ricca, M.A., Gustafson, K.B., Ziegler, Pilar, and Casazza, M.L., 2017b, Pinyon and juniper encroachment into sagebrush ecosystems impacts distribution and survival of greater sage-grouse: Rangeland Ecology \& Management, v. 70, no. 1, p. 25-38. [Also available at https://doi.org/10.1016/j.rama.2016.09.001.]

Coates, P.S., Prochazka, B.G., Ricca, M.A., Halstead, B.J., Casazza, M.L., Blomberg, E.J., Brussee, B.E., Wiechman, L., Tebbenkamp, J., Gardner, S.C., and Reese, K.P., 2018, The relative importance of intrinsic and extrinsic drivers to population growth vary among local populations of greater sage-grouse-An integrated population modeling approach: The Auk, Ornithological Advances, v. 135, no. 2, p. 240 261, accessed February 2018 at https://doi.org/10.1642/ AUK-17-137.1.

Coates, P.S., Prochazka, B.G., Ricca, M.A., Wann, G.T., Aldridge, C.L., Hanser, S.E., Doherty, K.E., O’Donnell, M.S., Edmunds, D.R., and Espinosa, S.P., 2017c, Hierarchical population monitoring of greater sage-grouse (Centrocercus urophasianus) in Nevada and CaliforniaIdentifying populations for management at the appropriate spatial scale: U.S. Geological Survey Open-File Report 2017-1089, 49 p., accessed December 2017 at https://doi. org/10.3133/ofr20171089.

Coates, P.S., Ricca, M.A., Prochazka, B.G., Brooks, M.L., Doherty, K.E., Kroger, Travis, Blomberg, E.J., Hagen, C.A., and Casazza, M.L., 2016e, Wildfire, climate, and invasive grass interactions negatively impact an indicator species by reshaping sagebrush ecosystems: Proceedings of the National Academy of Sciences of the United States of America, v. 113, no. 45, p. 12745-12750. [Also available at https://doi.org/10.1073/pnas.1606898113.]

Coates, P.S., Ricca, M.A., Prochazka, B.G., Doherty, K.E., Brooks, M.L., and Casazza, M.L., 2015, Long-term effects of wildfire on greater sage-grouse-Integrating population and ecosystem concepts for management in the Great Basin: U.S. Geological Survey Open-File Report 2015-1165, 42 p., accessed December 2017 at https://doi.org/10.3133/ ofr20151165.

Connelly, J.W., and Braun, C.E., 1997, Long-term changes in sage grouse Centrocercus urophasianus populations in western North America: Wildlife Biology, v. 3, no. 3, p. 229-234. 
Connelly, J.W., Knick, S.T., Schroeder, M.A., and Stiver, S.J., 2004, Conservation assessment of greater sage-grouse and sagebrush habitats: Cheyenne, Wyo., Western Association of Fish and Wildlife Agencies, 610 p., accessed December 2017 at https://sagemap.wr.usgs.gov/docs/Greater_Sagegrouse_Conservation_Assessment_060404.pdf.

Connelly, J.W., Reese, K.P., Fischer, R.A., and Wakkinen, W.L., 2000a, Response of a sage grouse breeding population to fire in southeastern Idaho: Wildlife Society Bulletin, v. 28, no. 1, p. 90-96. [Also available at http://www.jstor. $\mathrm{org} / \mathrm{stable} / 4617288$.

Connelly, J.W., Rinkes, E.T., and Braun, C.E., 2011, Characteristics of greater sage-grouse habitats-A landscape species at micro and macro scales, in Knick, S.T., and Connelly, J.W., eds., Greater sage-grouse-Ecology and conservation of a landscape species and its habitats: Berkeley, Calif., University of California Press, Studies in Avian Biology, no. 38, p. 69-83.

Connelly, J.W., Schroeder, M.A., Sands, A.R., and Braun, C.E., 2000b, Guidelines to manage sage grouse populations and their habitats: Wildlife Society Bulletin, v. 28, no. 4, p. 967-985. [Also available at http://www.jstor.org/ stable/3783856]

Conover, M.R., and Roberts, A.J., 2016, Declining populations of greater sage-grouse-Where and why: Human-Wildlife Interactions, v. 10, no. 2, p. 217-229. [Also available at https://digitalcommons.usu.edu/hwi/vol10/iss2/8.]

Cook, A.A., Messmer, T.A., and Guttery, M.R., 2017, Greater sage-grouse use of mechanical conifer reduction treatments in northwest Utah: Wildlife Society Bulletin, v. 41, no. 1, p. 27-33. [Also available at https://doi.org/10.1002/ wsb.742.]

Copeland, H.E., Sawyer, Hall, Monteith, K.L., Naugle, D.E., Pocewicz, Amy, Graf, Nicholas, and Kauffman, M.J., 2014, Conserving migratory mule deer through the umbrella of sage-grouse: Ecosphere, v. 5, no. 9, art. 117, p. 1-16. [Also available at https://doi.org/10.1890/ES14-00186.1.]

Crawford, J.A., Olson, R.A., West, N.E., Mosley, J.C., Schroeder, M.A., Whitson, T.D., Miller, R.F., Gregg, M.A., and Boyd, C.S., 2004, Ecology and management of sagegrouse and sage-grouse habitat: Journal of Range Management, v. 57, no. 1, p. 2-19. [Also available at https://doi. org/10.2111/1551-5028(2004)057[0002:EAMOSA]2.0 .CO;2.]

Creutzburg, M.K., Henderson, E.B., and Conklin, D.R., 2015, Climate change and land management impact rangeland condition and sage-grouse habitat in southeastern Oregon: AIMS Environmental Science, v. 2, no. 2, p. 203-236. [Also available at https://doi.org/10.3934/environsci.2015.2.203.]
Crist, M.R., Knick, S.T., and Hanser, S.E., 2017, Range-wide connectivity of priority areas for greater sage-grouseImplications for long-term conservation from graph theory: The Condor, v. 119, no. 1, p. 44-57. [Also available at https://doi.org/10.1650/CONDOR-16-60.1.]

Cross, T.B., Naugle, D.E., Carlson, J.C., and Schwartz, M.K., 2016, Hierarchical population structure in greater sagegrouse provides insight into management boundary delineation: Conservation Genetics, v. 17, no. 6, p. 1417-1433. [Also available at https://doi.org/10.1007/s10592-0160872-z.]

Cross, T.B., Naugle, D.E., Carlson, J.C., and Schwartz, M.K., 2017, Genetic recapture identifies long-distance breeding dispersal in greater sage-grouse (Centrocercus urophasianus): The Condor, v. 119, no. 1, p. 155-166. [Also available at https://doi.org/10.1650/CONDOR-16-178.1.]

Dahlgren, D.K., Guttery, M.R., Messmer, T.A., Caudill, Danny, Elmore, R.D., Chi, Renee, and Koons, D.N., 2016a, Evaluating vital rate contributions to greater sage-grouse population dynamics to inform conservation: Ecosphere, v. 7, no. 3, art. e01249, accessed December 2017 at https:// doi.org/10.1002/ecs2.1249.

Dahlgren, D.K., Larsen, R.T., Danvir, Rick, Wilson, George, Thacker, E.T., Black, T.A., Naugle, D.E., Connelly, J.W., and Messmer, T.A., 2015, Greater sage-grouse and range management-Insights from a 25-year case study in Utah and Wyoming: Rangeland Ecology \& Management, v. 68 , no. 5, p. 375-382. [Also available at https://doi. org/10.1016/j.rama.2015.07.003.]

Dahlgren, D.K., Messmer, T.A., Crabb, B.A., Larsen, R.T., Black, T.A., Frey, S.N., Thacker, E.T., Baxter, R.J., and Robinson, J.D., 2016b, Seasonal movements of greater sage-grouse populations in Utah-Implications for species conservation: Wildlife Society Bulletin, v. 40, no. 2, p. 288 299. [Also available at https://doi.org/10.1002/wsb.643.]

D'Antonio, C.M., and Vitousek, P.M., 1992, Biological invasions by exotic grasses, the grass/fire cycle, and global change: Annual Review of Ecology and Systematics, v. 23, no. 1, p. 63-87. [Also available at https://doi.org/10.1146/ annurev.es.23.110192.000431.]

Davis, D.M., and Crawford, J.A., 2015, Case study-Shortterm response of greater sage-grouse habitats to wildfire in mountain big sagebrush communities: Wildlife Society Bulletin, v. 39, no. 1, p. 129-137. [Also available at https:// doi.org/10.1002/wsb.505.]

Davis, D.M., Reese, K.P., and Gardner, S.C., 2014, Demography, reproductive ecology, and variation in survival of greater sage-grouse in northeastern California: Journal of Wildlife Management, v. 78, no. 8, p. 1343-1355. [Also available at https://doi.org/10.1002/jwmg.797.] 
Davis, D.M., Reese, K.P., Gardner, S.C., and Bird, K.L., 2015, Genetic structure of greater sage-grouse (Centrocercus urophasianus) in a declining, peripheral population: The Condor, v. 117, no. 4, p. 530-544. [Also available at http:// www.jstor.org/stable/90008982.]

Decker, K.L., Pocewicz, Amy, Harju, Seth, Holloran, Matt, Fink, M.M., Toombs, T.P., and Johnston, D.B., 2017, Landscape disturbance models consistently explain variation in ecological integrity across large landscapes: Ecosphere, v. 8, no. 4, art. e01775, accessed December 2017 at https://doi. org/10.1002/ecs2.1775.

Dinkins, J.B., Conover, M.R., Kirol, C.P., Beck, J.L., and Frey, S.N., 2014, Greater sage-grouse (Centrocercus urophasianus) select habitat based on avian predators, landscape composition, and anthropogenic features: The Condor, v. 116, no. 4, p. 629-642. [Also available at https://doi. org/10.1650/CONDOR-13-163.1.]

Dinkins, J.B., Conover, M.R., Kirol, C.P., Beck, J.L., and Frey, S.N., 2016a, Effects of common raven and coyote removal and temporal variation in climate on greater sagegrouse nesting success: Biological Conservation, v. 202, p. 50-58. [Also available at https://doi.org/10.1016/j. biocon.2016.08.011.]

Dinkins, J.B., Lawson, K.J., Smith, K.T., Beck, J.L., Kirol, C.P., Pratt, A.C., Conover, M.R., and Blomquist, F.C., 2017, Quantifying overlap and fitness consequences of migration strategy with seasonal habitat use and a conservation policy: Ecosphere, v. 8, no. 11, art. e01991, accessed December 2017 at https://doi.org/10.1002/ecs2.1991.

Dinkins, J.B., Smith, K.T., Beck, J.L., Kirol, C.P., Pratt, A.C., and Conover, M.R., 2016b, Microhabitat conditions in Wyoming's sage-grouse core areas-Effects on nest site selection and success: PLoS ONE, v. 11, no. 3, art. e0150798, accessed December 2017 at https://doi.org/10.1371/journal. pone. 0150798 .

Doherty, K.E., Evans, J.S., Coates, P.S., Juliusson, L.M., and Fedy, B.C., 2016, Importance of regional variation in conservation planning - A rangewide example of the greater sage-grouse: Ecosphere, v. 7, no. 10, art. e01462, accessed December 2017 at https://doi.org/10.1002/ecs2.1462.

Doherty, K.E., Naugle, D.E., Copeland, H.E., Pocewicz, Amy, and Kiesecker, J.M., 2011, Energy development and conservation tradeoffs - Systematic planning for greater sagegrouse in their eastern range, in Knick, S.T., and Connelly, J.W., eds., Greater sage-grouse-Ecology and conservation of a landscape species and its habitats: Berkeley, Calif., University of California Press, Studies in Avian Biology, no. 38 , p. $505-516$.
Doherty, K.E., Naugle, D.E., and Walker, B.L., 2010, Greater sage-grouse nesting habitat-The importance of managing at multiple scales: Journal of Wildlife Management, v. 74, no. 7, p. 1544-1553. [Also available at https://doi. org/10.2193/2009-043.]

Doherty, K.E., Naugle, D.E., Walker, B.L., and Graham, J.M., 2008, Greater sage-grouse winter habitat selection and energy development: Journal of Wildlife Management, v. 72, no. 1, p. 187-195. [Also available at https://doi. org/10.2193/2006-454.]

Donnelly, J.P., Naugle, D.E., Hagen, C.A., and Maestas, J.D., 2016, Public lands and private waters - Scarce mesic resources structure land tenure and sage-grouse distributions: Ecosphere, v. 7, no. 1, art. e01208, accessed December 2017 at https://doi.org/10.1002/ecs2.1208.

Donnelly, J.P., Tack, J.D., Doherty, K.E., Naugle, D.E., Allred, B.W., and Dreitz, V.J., 2017, Extending conifer removal and landscape protection strategies from sage-grouse to songbirds, a range-wide assessment: Rangeland Ecology \& Management, v. 70, no. 1, p. 95-105. [Also available at https://doi.org/10.1016/j.rama.2016.10.009.]

Dumroese, R.K., Luna, Tara, Richardson, B.A., Kilkenny, F.F., and Runyon, J.B., 2015, Conserving and restoring habitat for greater sage-grouse and other sagebrush-obligate wildlife-The crucial link of forbs and sagebrush diversity: Native Plants, v. 16, no. 3, p. 277-299. [Also available at http://npj.uwpress.org/content/16/3/276.short.]

Duvuvuei, O.V., Gruber-Hadden, N.W., Messmer, T.A., Guttery, M.R., and Maxfield, B.D., 2017, Contribution of translocated greater sage-grouse to population vital rates: Journal of Wildlife Management, v. 81, no. 6, p. 1033-1041. [Also available at https://doi.org/10.1002/jwmg.21264.]

Dzialak, M.R., Olson, C.V., Webb, S.L., Harju, S.M., and Winstead, J.B., 2015, Incorporating within- and betweenpatch resource selection in identification of critical habitat for brood-rearing greater sage-grouse: Ecological Processes, v. 4, no. 1, art. 5. [Also available at https://doi.org/10.1186/ s13717-015-0032-2.]

Edmunds, D.R., Aldridge, C.L., O’Donnell, M.S., and Monroe, A.P., 2017, Greater sage-grouse population trends across Wyoming: Journal of Wildlife Management, v. 82, p. 397-412. [Also available at https://doi.org/10.1002/ jwmg.21386.]

Ellsworth, L.M., Wrobleski, D.W., Kauffman, J.B., and Reis, S.A., 2016, Ecosystem resilience is evident 17 years after fire in Wyoming big sagebrush ecosystems: Ecosphere, v. 7, no. 12, art. e01618, accessed December 2017 at https://doi. org/10.1002/ecs2.1618. 
Falkowski, M.J., Evans, J.S., Naugle, D.E., Hagen, C.A., Carleton, S.A., Maestas, J.D., Khalyani, A.H., Poznanovic, A.J., and Lawrence, A.J., 2017, Mapping tree canopy cover in support of proactive prairie grouse conservation in western North America: Rangeland Ecology \& Management, v. 70, no. 1, p. 15-24. [Also available at https://doi.org/10.1016/j. rama.2016.08.002.]

Farzan, Shahla, Young, D.J.N., Dedrick, A.G., Hamilton, Matthew, Porse, E.C., Coates, P.S., and Sampson, Gabriel, 2015, Western juniper management-Assessing strategies for improving greater sage-grouse habitat and rangeland productivity: Environmental Management, v. 56, no. 3, p. 675-683. [Also available at https://doi.org/10.1007\% 2Fs00267-015-0521-1.]

Fedy, B.C., and Aldridge, C.L., 2011, The importance of within-year repeated counts and the influence of scale on long-term monitoring of sage-grouse populations: Journal of Wildlife Management, v. 75, no. 5, p. 1022-1033. [Also available at https://doi.org/10.1002/jwmg.155.]

Fedy, B.C., and Doherty, K.E., 2011, Population cycles are highly correlated over long time series and large spatial scales in two unrelated species - Greater sage-grouse and cottontail rabbits: Oecologia, v. 165, no. 4, p. 915-924. [Also available at https://doi.org/10.1007/s00442-010-17680.]

Fedy, B.C., Aldridge, C.L., Doherty, K.E., O’Donnell, M., Beck, J.L., Bedrosian, B., Holloran, M.J., Johnson, G.D., Kaczor, N.W., Kirol, C.P. and Mandich, C.A., 2012. Interseasonal movements of greater sage-grouse, migratory behavior, and an assessment of the core regions concept in Wyoming: The Journal of Wildlife Management, v. 76, n. 5, p.1062-1071. [Also available at https://doi.org/10.1002/ jwmg.337.]

Fedy, B.C., Kirol, C.P., Sutphin, A.L., and Maechtle, T.L., 2015a, The influence of mitigation on sage-grouse habitat selection within an energy development field: PloS ONE, v. 10, no. 4, art. e0121603, accessed December 2017 at https://doi.org/10.1371/journal.pone.0121603.

Fedy, B.C., O’Donnell, M.S., and Bowen, Z.H., 2015b, Largescale control site selection for population monitoring-An example assessing sage-grouse trends: Wildlife Society Bulletin, v. 39, no. 4, p. 700-712. [Also available at http:// www.jstor.org/stable/wildsocibull2011.39.4.700.]

Fedy, B.C., Row, J.R., and Oyler-McCance, S.J., 2017, Integration of genetic and demographic data to assess population risk in a continuously distributed species: Conservation Genetics, v. 18, no. 1, p. 89-104. [Also available at https:// doi.org/10.1007\%2Fs10592-016-0885-7.]
Fike, J.A., Oyler-McCance, S.J., Zimmerman, S.J., and Castoe, T.A., 2015, Development of 13 microsatellites for Gunnison sage-grouse (Centrocercus minimus) using nextgeneration shotgun sequencing and their utility in greater sage-grouse (Centrocercus urophasianus): Conservation Genetics Resources, v. 7, no. 1, p. 211-214. [Also available at https://link.springer.com/article/10.1007\%2Fs12686-0140336-z.]

Freese, M.T., Petersen, S.L., and Miller, R.F., 2016, Spatial analysis of greater sage-grouse habitat use in relation to landscape level habitat structure: Journal of Ecosystem and Ecography, v. 6, no. 3, art. 1000205. [Also available at https://doi.org/10.4172/2157-7625.1000205.]

Fremgen, A.L., Hansen, C.P., Rumble, M.A., Gamo, R.S., and Millspaugh, J.J., 2016, Male greater sage-grouse detectability on leks: Journal of Wildlife Management, v. 80, no. 2, p. 266-274. [Also available at https://doi.org/10.1002/ jwmg.1001.]

Fremgen, M.R., Gibson, Daniel, Ehrlich, R.L., Krakauer, A.H., Forbey, J.S., Blomberg, E.J., Sedinger, J.S., and Patricelli, G.L., 2017, Necklace-style radio-transmitters are associated with changes in display vocalizations of male greater sagegrouse: Wildlife Biology, art. wlb. 00236. [Also available at https://doi.org/10.2981/wlb.00236.]

Gamo, R.S., and Beck, J.L., 2017, Effectiveness of Wyoming's sage-grouse core areas - Influences on energy development and male lek attendance: Environmental Management, v. 59, no. 2, p. 189-203. [Also available at https://doi. org/10.1007/s00267-016-0789-9.]

Garman, S.L., 2017, A simulation framework for assessing physical and wildlife impacts of oil and gas development scenarios in southwestern Wyoming: Environmental Modeling and Assessment, v. 23, no. 1, p. 39-56. [Also available at https://doi.org/10.1007/s10666-017-9559-1.]

Garton, E.O., Connelly, J.W., Horne, J.S., Hagen, C.A., Moser, Ann, and Schroeder, M.A., 2011, Greater sage-grouse population dynamics and probability of persistence, in Knick, S.T., and Connelly, J.W., eds., Greater sage-grouse-Ecology and conservation of a landscape species and its habitats: Berkeley, Calif., University of California Press, Studies in Avian Biology, no. 38, p. 293-381.

Gibson, Daniel, Blomberg, E.J., and Sedinger, J.S., 2016a, Evaluating vegetation effects on animal demographicsThe role of plant phenology and sampling bias: Ecology and Evolution, v. 6, no. 11, p. 3621-3631. [Also available at https://doi.org/10.1002\%2Fece3.2148.] 
Gibson, Daniel, Blomberg, E.J., Atamian, M.T., and Sedinger, J.S., 2015, Observer effects strongly influence estimates of daily nest survival probability but do not substantially increase rates of nest failure in greater sage-grouse: The Auk, v. 132, no. 2, p. 397-407. [Also available at https:// doi.org/10.1642/AUK-14-197.1.]

Gibson, Daniel, Blomberg, E.J., Atamian, M.T., and Sedinger, J.S., 2016b, Nesting habitat selection influences nest and early offspring survival in greater sage-grouse: The Condor, v. 118, no. 4, p. 689-702. [Also available at https://doi. org/10.1650/CONDOR-16-62.1.]

Gibson, Daniel, Blomberg, E.J., Atamian, M.T., and Sedinger, J.S., 2017, Weather, habitat composition, and female behavior interact to modify offspring survival in greater sagegrouse: Ecological Applications, v. 27, no. 1, p. 168-181. [Also available at https://doi.org/10.1002/eap.1427.]

Green, A.W., Aldridge, C.L., and O’Donnell, M.S., 2017, Investigating impacts of oil and gas development on greater sage-grouse: Journal of Wildlife Management, v. 81, no. 1, p. 46-57. [Also available at https://doi.org/10.1002/ jwmg.21179.]

Gregg, M.A., and Crawford, J.A., 2009, Survival of greater sage-grouse chicks and broods in the Northern Great Basin: Journal of Wildlife Management, v. 73, no. 6, p. 904-913. [Also available at https://doi.org/10.2193/2007-410.]

Gregg, M.A., Crawford, J.A., Drut, M.S., and DeLong, A.K., 1994, Vegetative cover and predation of sage grouse nests in Oregon: Journal of Wildlife Management, v. 58, no. 1, p. 162-166. [Also available at https://doi. org $/ 10.2307 / 3809563$.]

Gregory, A.J., and Beck, J.L., 2014, Spatial heterogeneity in response of male greater sage-grouse lek attendance to energy development: PloS One, v. 9, no. 6, art. e97132. [Also available at https://doi.org/10.1371/journal. pone.0097132.]

Gruber-Hadden, N.W., Messmer, T.A., Maxfield, B.D., Koons, D.N., and Guttery, M.R., 2016, Population vital rates of resident and translocated female greater sage-grouse: Journal of Wildlife Management, v. 80, no. 4, p. 753-760. [Also available at https://doi.org/10.1002/jwmg.1062.]

Hagen, C.A., 2011, Predation on greater sage grouse-Facts, process, and effects, in Knick, S.T., and Connelly, J.W., eds., Greater sage-grouse - Ecology and conservation of a landscape species and its habitats: Berkeley, Calif., University of California Press, Studies in Avian Biology, no. 38, p. $95-100$.

Hagen, C.A., and Anthony, R.G., 2010, Greater sage-grouse conservation assessment and strategy for Oregon-A plan to maintain and enhance populations and habitat: Bend, Oreg., Oregon Department of Fish and Wildlife, 189 p.
Hagen, C.A., Connelly, J.W., and Schroeder, M.A., 2007, A meta-analysis of greater sage-grouse Centrocercus urophasianus nesting and brood-rearing habitats: Wildlife Biology, v. 13, p. 42-50. [Also available at https://doi. org/10.2981/0909-6396(2007)13\%5b42:AMOGSC $\% 5 \mathrm{~d} 2.0$ .CO;2.]

Hanks, E.M., Hooten, M.B., Knick, S.T., Oyler-McCance, S.J., Fike, J.A., Cross, T.B., and Schwartz, M.K., 2016, Latent spatial models and sampling design for landscape genetics: Annals of Applied Statistics, v. 10, no. 2, p. 1041-1062. [Also available at https://doi.org/10.1214/16-AOAS929.]

Hansen, C.P., Schreiber, L.A., Rumble, M.A., Millspaugh, J.J., Gamo, R.S., Kehmeier, J.W. and Wojcik, N., 2016a, Microsite selection and survival of greater sage-grouse nests in south-central Wyoming: The Journal of Wildlife Management, v. 80, n. 5, p. 862-876. [Also available at https://doi. org/10.1002/jwmg.1065.]

Hansen, E.P., Stewart, A.C., and Frey, S.N., 2016b, Influence of transmission line construction on winter sage-grouse habitat use in southern Utah: Human-Wildlife Interactions, v. 10, no. 2, p. 169-187. [also available at https://digitalcommons.usu.edu/hwi/vol10/iss2/5/.]

Hanser, S.E., and Knick, S.T., 2011, Greater sage-grouse as an umbrella species for shrubland passerine birds-A multiscale assessment, in Knick, S.T., and Connelly, J.W., eds., Greater sage grouse-Ecology and conservation of a landscape species and its habitats: Berkeley, Calif., University of California Press, Studies in Avian Biology, no. 38, p. $475-488$.

Hanser, S.E., and Manier, D.J., 2013, Greater sage-grouse national research strategy: U.S. Geological Survey Scientific Investigations Report 2013-5167, 46 p. plus appendix, accessed December 2017 at https://pubs.usgs.gov/ $\operatorname{sir} / 2013 / 5167 /$.

Heinrichs, J.A., Aldridge, C.L., Gummer, D.L., Monroe, A.P., and Schumaker, N.H., 2018, Prioritizing actions for the recovery of endangered species-Emergent insights from greater sage-grouse simulation modeling: Biological Conservation, v. 218, p 134-143. [Also available at https://doi. org/10.1016/j.biocon.2017.11.022.]

Heinrichs, J.A., Aldridge, C.L., O'Donnell, M.S., and Schumaker, N.H., 2017a, Using dynamic population simulations to extend resource selection analyses and prioritize habitats for conservation: Ecological Modelling, v. 359, p. 449-459. [Also available at https://doi.org/10.1016/j. ecolmodel.2017.05.017.]

Heinrichs, J.A., Lawler, J.J., Schumaker, N.H., Wilsey, C.B., Newcomb, Kira, and Aldridge, C.L., 2017b, A multispecies test of source-sink indicators to prioritize habitat for declining populations: Conservation Biology, 19 p. [Also available at https://doi.org/10.1111/cobi.13058.] 
Hess, J.E., and Beck, J.L., 2012, Disturbance factors influencing greater sage-grouse lek abandonment in north-central Wyoming: Journal of Wildlife Management, v. 76, no. 8, p. 1625-1634. [Also available at https://doi.org/10.1002/ jwmg.417.]

Holloran, M.J., and Anderson, S.H., 2005, Spatial distribution of greater sage-grouse nests in relatively contiguous sagebrush habitats: The Condor, v. 107, no. 4, p. 742-752. [Also available at https://doi.org/10.1650/7749.1.]

Holloran, M.J., Fedy, B.C., and Dahlke, John, 2015, Winter habitat use of greater sage-grouse relative to activity levels at natural gas well pads: Journal of Wildlife Management, v. 79, no. 4, p. 630-640. [Also available at https://doi. org/10.1002/jwmg.877.]

Holloran, M.J., Heath, B.J., Lyon, A.G., Slater, S.J., Kuipers, J.L., and Anderson, S.H., 2005, Greater sage-grouse nesting habitat selection and success in Wyoming: Journal of Wildlife Management, v. 69, no. 2, p. 638-649. [Also available at https://doi.org/10.2193/0022-541X(2005)069[0638:GSN HSA]2.0.CO;2.]

Homer, C.G., Xian, George, Aldridge, C.L., Meyer, D.K., Loveland, T.R., and O'Donnell, M.S., 2015, Forecasting sagebrush ecosystem components and greater sage-grouse habitat for 2050 - Learning from past climate patterns and Landsat imagery to predict the future: Ecological Indicators, v. 55, p. 131-145. [Also available at https://doi. org/10.1016/j.ecolind.2015.03.002.]

Integrated Rangeland Fire Management Strategy Actionable Science Plan Team, 2016, The Integrated Rangeland Fire Management Strategy actionable science plan: Washington, D.C., U.S. Department of the Interior, 128 p. accessed December 2017 at http://integratedrangelandfiremanagementstrategy.org/wp-content/uploads/2016/10/IRFMS_ Actionable_Science_Plan.pdf

Jahner, J.P., Gibson, D., Weitzman, C.L., Blomberg, E.J., Sedinger, J.S., and Parchman, T.L., 2016, Fine-scale genetic structure among greater sage-grouse leks in central Nevada: BMC Evolutionary Biology, v. 16, no. 1, art. 127. [Also available at https://doi.org/10.1186/s12862-016-0702-4.]

Johnson, D.H., 1980, The comparison of usage and availability measurements for evaluating resource preference: Ecology, v. 61, no. 1, p. 65-71. [Also available at https:// doi.org/10.2307/1937156.]

Juliusson, L.M., and Doherty, K.E., 2017, Oil and gas development exposure and conservation scenarios for greater sage-grouse - Combining spatially explicit modeling with GIS visualization provides critical information for management decisions: Applied Geography, v. 80, p. 98-111. [Also available at https://doi.org/10.1016/j.apgeog.2017.01.006.]
Kaczor, N.W., Jensen, K.C., Klaver, R.W., Rumble, M.A., Herman-Brunson, K.M., and Swanson, C.C., 2011, Nesting success and resource selection of greater sage-grouse, in Sandercock, B.K., Martin, K., and Segelbacher, G., eds., Ecology, conservation, and management of grouse: Berkeley, Calif., University of California Press, Studies in Avian Biology, no. 39, p. 107-118.

Kane, Kristin, Sedinger, J.S., Gibson, Daniel, Blomberg, Erik, and Atamian, M.T., 2017, Fitness landscapes and life-table response experiments predict the importance of local areas to population dynamics: Ecosphere, v. 8, no. 7, art. e01869, accessed December 2017 at https://doi.org/10.1002/ ecs2.1869.

Kirol, C.P., Beck, J.L., Huzurbazar, S.V., Holloran, M.J., and Miller, S.N., 2015a, Identifying greater sage-grouse source and sink habitats for conservation planning in an energy development landscape: Ecological Applications, v. 25 , no. 4 , p. $968-990$. [Also available at https://doi. org/10.1890/13-1152.1.]

Kirol, C.P., Sutphin, A.L., Bond, Laura, Fuller, M.R., and Maechtle, T.L., 2015b, Mitigation effectiveness for improving nesting success of greater sage-grouse influenced by energy development: Wildlife Biology, v. 21, no. 2, p. 98-109. [Also available at https://doi.org/10.2981/ wlb.00002.]

Knick, S.T., 2011, Historical development, principal federal legislation, and current management of sagebrush habitats-Implications for conservation, in Knick, S.T., and Connelly, J.W., eds., Greater sage-grouse-Ecology and conservation of a landscape species and its habitats: Berkeley, Calif., University of California Press, Studies in Avian Biology, no. 38, p. 13-31.

Knick, S.T., and Connelly, J.W., eds., 2011, Greater sagegrouse ecology and conservation of a landscape species and its habitats: Berkeley, Calif., University of California Press, Studies in Avian Biology, no. 38, 564 p.

Knick, S.T., Dobkin, D.S., Rotenberry, J.T., Schroeder, M.A., Vander Haegen, W.M., and Van Riper, Charles, III, 2003, Teetering on the edge or too late? Conservation and research issues for avifauna of sagebrush habitats: The Condor, v. 105, no. 4, p. 611-634. [Also available at https:// doi.org/10.1650/7329.]

Knick, S.T., and Hanser, S.E., 2011, Connecting pattern and process in greater sage-grouse populations and sagebrush landscapes, in Knick, S.T., and Connelly, J.W., eds., Greater sage-grouse ecology and conservation of a landscape species and its habitats: Berkeley, Calif., University of California Press, Studies in Avian Biology, no. 38, p. 383-406. 
Knick, S.T., Hanser, S.E., Miller, R.F., Pyke, D.A., Wisdom, M.J., Finn, S.P., Rinkes, E.T., and Henny, C.J., 2011, Ecological influence and pathways of land use in sagebrush, in Knick, S.T., and Connelly, J.W., eds., 2011, Greater sagegrouse ecology and conservation of a landscape species and its habitats: Berkeley, Calif., University of California Press, Studies in Avian Biology, no. 38, p. 203-251.

Knick, S.T., Hanser, S.E., and Preston, K.L., 2013, Modeling ecological minimum requirements for distribution of greater sage-grouse leks-Implications for population connectivity across their western range, USA: Ecology and Evolution, v. 3 no. 6, p. 1539-1551. [Also available at https://doi. org/10.1002/ece3.557.]

Knutson, K.C., Pyke, D.A., Wirth, T.A., Arkle, R.S., Pilliod, D.S., Brooks, M.L., Chambers, J.C., and Grace, J.B., 2014, Long-term effects of seeding after wildfire on vegetation in Great Basin shrubland ecosystems: Journal of Applied Ecology, v. 51, no. 5, p. 1414-1424. [Also available at https:// doi.org/10.1111/1365-2664.12309.]

Kolada, E.J., Sedinger, J.S., and Casazza, M.L., 2009, Nest site selection by greater sage-grouse in Mono County, California: Journal of Wildlife Management, v. 73 , no. 8 , p. 1333-1340. [Also available at https://doi. org/10.2193/2008-338.]

LeBeau, C.W., Beck, J.L., Johnson, G.D., Nielson, R.M., Holloran, M.J., Gerow, K.G., and McDonald, T.L., 2017a, Greater sage-grouse male lek counts relative to a wind energy development: Wildlife Society Bulletin, v. 41, no. 1, p. 17-26. [Also available at https://doi.org/10.1002/ wsb.725.]

LeBeau, C.W., Johnson, G.D., Holloran, M.J., Beck, J.L., Nielson, R.M., Kauffman, M.E., Rodemaker, E.J., and McDonald, T.L., 2017b, Greater sage-grouse habitat selection, survival, and wind energy infrastructure: Journal of Wildlife Management, v. 81, no. 4, p. 690-711. [Also available at https://doi.org/10.1002/jwmg.21231.]

Leu, Matthias, and Hanser, S.E., 2011, Influences of the human footprint on sagebrush landscape patterns-Implications for sage-grouse conservation, in Knick, S.T., and Connelly, J.W., eds., Greater sage-grouse ecology and conservation of a landscape species and its habitats: Berkeley, Calif., University of California Press, Studies in Avian Biology, no. 38 , p. $253-271$.

Levin, S.A., 1992, The problem of pattern and scale in ecology: Ecology, v. 73, no. 6, p. 1943-1967. [Also available at https://doi.org/10.2307/1941447.]
Lockyer, Z.B., Coates, P.S., Casazza, M.L., Espinosa, Shawn, and Delehanty, D.J., 2013, Greater sage-grouse nest predators in the Virginia Mountains of northwestern Nevada: Journal of Fish and Wildlife Management, v. 4, no. 2, p. 242-255. [Also available at https://doi. org/10.3996/122012-JFWM-110R1.]

Lockyer, Z.B., Coates, P.S., Casazza, M.L., Espinosa, Shawn, and Delehanty, D.J., 2015, Nest-site selection and reproductive success of greater sage-grouse in a fire-affected habitat of northwestern Nevada: Journal of Wildlife Management, v. 79, no. 5, p. 785-797. [Also available at https://doi. org/10.1002/jwmg.899.]

Mabray, S.T., and Conover, M.R., 2015, Microhabitat selection by greater sage-grouse hens during brood rearing: Human-Wildlife Interactions, v. 9, no. 2, p. 219-228. [Also available at https://digitalcommons.usu.edu/hwi/vol9/ iss $2 / 11 /$.]

Maestas, J.D., Campbell, S.B., Chambers, J.C., Pellant, Mike, and Miller, R.F., 2016, Tapping soil survey information for rapid assessment of sagebrush ecosystem resilience and resistance: Rangelands, v. 38, no. 3, p. 120-128. [Also available at https://doi.org/10.1016/j.rala.2016.02.002.]

Manier, D.J., Wood, D.J.A., Bowen, Z.H., Donovan, R.M., Holloran, M.J., Juliusson, L.M., Mayne, K.S., OylerMcCance, S.J., Quamen, F.R., Saher, D.J., and Titolo, A.J., 2013, Summary of science, activities, programs, and policies that influence the rangewide conservation of Greater Sage-Grouse (Centrocercus urophasianus): U.S. Geological Survey Open-File Report 2013-1098, 170 p., accessed December 2017 at https://pubs.usgs.gov/of/2013/1098/.

Manier, D.J., Bowen, Z.H., Brooks, M.L., Casazza, M.L., Coates, P.S., Deibert, P.A., Hanser, S.E., and Johnson, D.H., 2014, Conservation buffer distance estimates for greater sage-grouse-A review: U.S. Geological Survey OpenFile Report 2014-1239, 14 p., accessed December 2017 at https://doi.org/10.3133/ofr20141239.

Manly, B.F.J., McDonald, L.L., Thomas, D.L., McDonald, T.L. and Erickson, W.P., 2002, Resource selection by animals - Statistical design and analysis for field studies (2d ed.): Boston, Mass., Kluwer Academic Publishers, 209 p.

McCaffery, Rebecca, and Lukacs, P.M., 2016, A generalized integrated population model to estimate greater sage-grouse population dynamics: Ecosphere, v. 7, no. 11, art. e01585, accessed December 2017 at https://doi.org/10.1002/ ecs2.1585.

McCaffery, Rebecca, Nowak, J.J., and Lukacs, P.M., 2016, Improved analysis of lek count data using $N$-mixture models: Journal of Wildlife Management, v. 80, no. 6, p. 1011-1021. [Also available at https://doi.org/10.1002/ jwmg.21094.] 
McConnell, M.D., Monroe, A.P., Burger, L.W., and Martin, J.A., 2017, Timing of nest vegetation measurement may obscure adaptive significance of nest-site characteristics-A simulation study: Ecology and Evolution, v. 7, no. 4, p. 1259-1270. [Also available at https://doi. org $/ 10.1002 \% 2 F e c e 3.2767$.]

McIver, James, and Brunson, Mark, 2014, Multidisciplinary, multisite evaluation of alternative sagebrush steppe restoration treatments-The SageSTEP project: Rangeland Ecology \& Management, v. 67, no. 5, p. 435-439. [Also available at https://doi.org/10.2111/REM-D-14-00085.1.]

Meinke, C.W., Knick, S.T., and Pyke, D.A., 2009, A spatial model to prioritize sagebrush landscapes in the Intermountain West (USA) for restoration: Restoration Ecology, v. 17, no. 5, p. 652-659. [Also available at https://doi.org/10.1111/ j.1526-100X.2008.00400.x.]

Miller, R.F., Bates, J.D., Svejcar, T.J., Pierson, F.B., and Eddleman, L.E., 2005, Biology, ecology, and management of western juniper: Corvallis, Oreg., Oregon State University; Technical Bulletin, no. 152, 77 p., accessed December 2017 at https://catalog.extension.oregonstate.edu/tb152.

Miller, R.F., Chambers, J.C., and Pellant, Mike, 2014, A field guide for selecting the most appropriate treatment in sagebrush and piñon-juniper ecosystems in the Great BasinEvaluating resilience to disturbance and resistance to invasive annual grasses, and predicting vegetation response: U.S. Department of Agriculture, Forest Service, Rocky Mountain Research Station, General Technical Report RMRS-GTR-322-rev, 66 p., accessed December 2017 at https://www.fs.fed.us/rm/pubs/rmrs_gtr322.pdf.

Miller, R.F., Chambers, J.C., and Pellant, Mike, 2015, A field guide for rapid assessment of post wildfire recovery potential in sagebrush and piñon-juniper ecosystems in the Great Basin-Evaluating resilience to disturbance and resistance to invasive annual grasses and predicting vegetation response: U.S. Department of Agriculture, Forest Service, Rocky Mountain Research Station, General Technical Report RMRS-GTR-338, 70 p., accessed December 2017 at https://www.fs.fed.us/rm/pubs/rmrs_gtr338.pdf.

Miller, R.F., and Eddleman, L.L., 2001, Spatial and temporal changes of sage grouse habitat in the sagebrush biome: Corvallis, Oreg., Oregon State University Agricultural Experiment Station, Technical Bulletin 151, 26 p. [Also available at https://catalog.extension.oregonstate.edu/tb151.]

Miller, R.F., Knick, S.T., Pyke, D.A., Meinke, C.W., Hanser, S.E., Wisdom, M.J., and Hild, A.L., 2011, Characteristics of sagebrush habitats and limitations to long-term conservation, in Knick S.T., and Connelly, J.W., eds., Greater sagegrouse-Ecology and conservation of a landscape species and its habitats: Berkeley, Calif., University of California Press, Studies in Avian Biology, no. 38, p. 145-184.
Miller, R.F., and Rose, J.A., 1999, Fire history and western juniper encroachment in sage-brush steppe: Journal of Range Management, v. 52, no. 6, p. 550-559. [Also available at https://www.jstor.org/stable/4003623.]

Monroe, A.P., Edmunds, D.R., and Aldridge, C.L., 2016, Effects of lek count protocols on greater sage-grouse population trend estimates: Journal of Wildlife Management, v. 80, no. 4, p. 667-678. [Also available at https://doi. org/10.1002/jwmg.1050.]

Monroe, A.P., Aldridge, C.L., Assal, T.J., Veblen, K.E., Pyke, D.A., and Casazza, M.L., 2017, Patterns in greater sage-grouse population dynamics correspond with public grazing records at broad scales: Ecological Applications, v. 27, no. 4, p. 1096-1107. [Also available at https://doi. org/10.1002/eap.1512.]

Nelle, P.J., Reese, K.P., and Connelly, J.W., 2000, Long-term effects of fire on sage grouse habitat: Journal of Range Management, v. 53, no. 6, p. 586-591. [Also available at https://www.jstor.org/stable/4003151.]

Newton, R.E., Tack, J.D., Carlson, J.C., Matchett, M.R., Fargey, P.J., and Naugle, D.E., 2017, Longest sage-grouse migratory behavior sustained by intact pathways: Journal of Wildlife Management, v. 81, no. 6, p. 962-972. [Also available at https://doi.org/10.1002/jwmg.21274.]

Orning, E.K., and Young, J.K., 2016, Impacts of coyote removal on space use by greater sage grouse: Human-Wildlife Interactions, v. 10, no. 2, p. 144-156. [Also available at https://digitalcommons.usu.edu/hwi/vol10/iss2/3/.]

Ott, J.E., Cox, R.D., Shaw, N.L., Newingham, B.A., Ganguli, A.C., Pellant, Mike, Roundy, B.A., and Eggett, D.L., 2016, Postfire drill-seeding of Great Basin plants-Effects of contrasting drills on seeded and nonseeded species: Rangeland Ecology \& Management, v. 69, no. 5, p. 373-385. [Also available at https://doi.org/10.1016/j.rama.2016.05.001.]

Oyler-McCance, S.J., Cornman, R.S., Jones, K.L., and Fike, J.A., 2015a, Genomic single-nucleotide polymorphisms confirm that Gunnison and Greater Sage-Grouse are genetically well differentiated and that the Bi-State population is distinct: The Condor, v. 117, no. 2, p. 217-227. [Also available at https://doi.org/10.1650/CONDOR-14-174.1.]

Oyler-McCance, S.J., Cornman, R.S., Jones, K.L., and Fike, J.A, 2015b, Z chromosome divergence, polymorphism and relative effective population size in a genus of lekking birds: Heredity, v. 115, no. 5, p. 452-459. [Also available at https://doi.org/10.1038\%2Fhdy.2015.46.]

Oyler-McCance, S.J., Taylor, S.E., and Quinn, T.W., 2005, A multilocus population genetic survey of the greater sagegrouse across their range: Molecular Ecology, v. 14, no. 5, p. 1293-1310. [Also available at https://doi.org/10.1111/ j.1365-294X.2005.02491.x.] 
Palmquist, K.A., Schlaepfer, D.R., Bradford, J.B., and Lauenroth, W.K., 2016a, Mid-latitude shrub steppe plant communities - Climate change consequences for soil water resources: Ecology, v. 97, no. 9, p. 2342-2354. [Also available at https://doi.org/10.1002/ecy.1457.]

Palmquist, K.A., Schlaepfer, D.R., Bradford, J.B., and Lauenroth, W.K., 2016b, Spatial and ecological variation in dryland ecohydrological responses to climate change: implications for management: Ecosphere, v. 7, no. 11, art. e01590, accessed December 2017 at https://doi.org/10.1002/ ecs2.1590.

Patricelli, G.L., Blickley, J.L., and Hooper, S.L., 2013, Recommended management strategies to limit anthropogenic noise impacts on greater sage-grouse in Wyoming: HumanWildlife Interactions, v. 7, no. 2, p. 230-249. [Also available at https://digitalcommons.usu.edu/hwi/vol7/iss2/15/.]

Patterson, R.L, 1952, The Sage Grouse in Wyoming: Denver, Colo., Sage Books, Inc, 341 p.

Peebles, L.W., and Conover, M.R., 2016, Effectiveness of the toxicant DRC-1339 in reducing populations of common ravens in Wyoming: Wildlife Society Bulletin v. 40, no. 2, p. 281-287. [Also available at https://doi.org/10.1002/ wsb.661.]

Peebles, L.W., Conover, M.R., and Dinkins, J.B., 2017, Adult sage-grouse numbers rise following raven removal or an increase in precipitation: Wildlife Society Bulletin v. 41, no. 3, p. 471-478. [Also available at https://doi.org/10.1002/ wsb.788.]

Pennington, V.E., Palmquist, K.A., Bradford, J.B., and Lauenroth, W.K., 2017, Climate and soil texture influence patterns of forb species richness and composition in big sagebrush plant communities across their spatial extent in the western US: Plant Ecology, v. 218, no. 8, p. 957-970. [Also available at https://doi.org/10.1007/s11258-017-0743-9.]

Pennington, V.E., Schlaepfer, D.R., Beck, J.L., Bradford, J.B., Palmquist, K.A., and Lauenroth, W.K., 2016, Sagebrush, Greater Sage-Grouse, and the occurrence and importance of forbs: Western North American Naturalist, v. 76, no. 3, p. 298-312. [Also available at https://doi. org/10.3398/064.076.0307.]

Pollock, K.H., Nichols, J.D., Simons, T.R., Farnsworth, G.L., Bailey, L.L., and Sauer, J.R., 2002, Large scale wildlife monitoring studies - Statistical methods for design and analysis: Environmetrics, v. 13, no. 2, p. 105-119. [Also available at https://doi.org/10.1002/env.514.]
Prochazka, B.G., Coates, P.S., Ricca, M.A., Casazza, M.L., Gustafson, K.B., and Hull, J.M., 2017, Encounters with pinyon-juniper influence riskier movements in Greater Sage-Grouse across the Great Basin: Rangeland Ecology \& Management, v. 70, no. 1, p. 39-49. [Also available at https://doi.org/10.1016/j.rama.2016.07.004.]

Pyke, D.A., 2011, Restoring and rehabilitating sagebrush habitats, in Knick, S.T., and Connelly, J.W., eds., Greater SageGrouse-Ecology and conservation of a landscape species and its habitats: Berkeley, Calif., University of California Press, Studies in Avian Biology, no. 38, p. 531-548.

Pyke, D.A., Chambers, J.C., Pellant, Mike, Knick, S.T., Miller, R.F., Beck, J.L., Doescher, P.S., Schupp, E.W., Roundy, B.A., Brunson, Mark, and McIver, J.D., 2015a, Restoration handbook for sagebrush steppe ecosystems with emphasis on greater sage-grouse habitat-Part 1. Concepts for understanding and applying restoration: U.S. Geological Survey Circular 1416, 44 p., accessed December 2017 at https://doi. org/10.3133/cir1416.

Pyke, D.A., Chambers, J.C., Pellant, Mike, Miller, R.F., Beck, J.L., Doescher, P.S., Roundy, B.A., Schupp, E.W., Knick, S.T., Brunson, Mark, and McIver, J.D., 2017, Restoration handbook for sagebrush steppe ecosystems with emphasis on greater sage-grouse habitat-Part 3. Site level restoration decisions: U.S. Geological Survey Circular 1426, 62 p., accessed December 2017 at https://doi.org/10.3133/cir1426.

Pyke, D.A., Knick, S.T., Chambers, J.C., Pellant, Mike, Miller, R.F., Beck, J.L., Doescher, P.S., Schupp, E.W., Roundy, B.A., Brunson, Mark, and McIver, J.D., 2015b, Restoration handbook for sagebrush steppe ecosystems with emphasis on greater sage-grouse habitat-Part 2. Landscape level restoration decisions: U.S. Geological Survey Circular 1418, 21 p., accessed December 2017 at https://doi.org/10.3133/ cir1418.

Reese, K.P., and Bowyer, R.T.,eds., 2007, Monitoring populations of sage-grouse: Moscow, Idaho, University of Idaho, College of Natural Resources Experiment Station Bulletin 88, 54 p., accessed December 2017 at https://sgrp.usu. edu/files/uploads/grouseProcdngs4.pdf.

Reese, K.P., and Connelly, J.W., 2011, Harvest management for Greater Sage-Grouse-A changing paradigm for game bird management, in Knick, S.T., and Connelly, J.W., eds., Greater Sage-Grouse-Ecology and conservation of a landscape species and its habitats: Berkeley, Calif., University of California Press, Studies in Avian Biology, no. 38, p. 101-111. 
Reinhardt, J.R., Naugle, D.E., Maestas, J.D., Allred, Brady, Evans, Jeffrey, and Falkowski, Michael, 2017, Nextgeneration restoration for sage-grouse - A framework for visualizing local conifer cuts within a landscape context: Ecosphere, v. 8, no. 7, art. e01888, accessed December 2017 at https://doi.org/10.1002/ecs2.1888.]

Rhodes, E.C., Bates, J.D., Sharp, R.N., and Davies, K.W., 2010, Fire effects on cover and dietary resources of sage-grouse habitat: Journal of Wildlife Management, v. 74, no. 4, p. 755-764. [Also available at https://doi. org/10.2193/2009-143.]

Rice, M.B., Rossi, L.G., and Apa, A.D., 2016, Seasonal habitat use by greater sage-grouse (Centrocercus urophasianus) on a landscape with low density oil and gas development: PLoS ONE, v. 11, no. 10, art. e0165399, accessed December 2017 at https://doi.org/10.1371/journal.pone.0165399.]

Row, J.R., and Fedy, B.C., 2017, Spatial and temporal variation in the range-wide cyclic dynamics of greater sagegrouse: Oecologia, v. 185, no. 4, p. 687-698. [Also available at https://doi.org/10.1007/s00442-017-3970-9.]

Row, J.R., Knick, S.T., Oyler-McCance, S.J., Lougheed, S.C., and Fedy, B.C., 2017, Developing approaches for linear mixed modeling in landscape genetics through landscapedirected dispersal simulations: Ecology and Evolution, v. 7, no. 11, p. 3751-3761. [Also available at https://doi. org $/ 10.1002 \% 2$ Fece 3.2825 .]

Row, J.R., Oyler-McCance, S.J., and Fedy, B.C., 2016, Differential influences of local subpopulations on regional diversity and differentiation for greater sage-grouse (Centrocercus urophasianus): Molecular Ecology, v. 25, no. 18, p. 4424-4437. [Also available at https://doi.org/10.1111/ mec.13776.]

Row, J.R., Oyler-McCance, S.J., Fike, J.A., O’Donnell, M.S., Doherty, K.E., Aldridge, C.L., Bowen, Z.H., and Fedy, B.C., 2015, Landscape characteristics influencing the genetic structure of greater sage-grouse within the stronghold of their range-A holistic modeling approach: Ecology and Evolution, v. 5, no. 10, p. 1955-1969. [Also available at https://doi.org/10.1002/ece3.1479.]

Sage-grouse National Technical Team, 2011, A report on national greater sage-grouse conservation measures: Bureau of Land Management, 74 p., accessed December 2017 at https://eplanning.blm.gov/epl-front-office/projects/ lup/9153/39961/41912/WySG_Tech-Team-Report-Conservation-Measure_2011.pdf.

Sandford, C.P., Kohl, M.T., Messmer, T.A., Dahlgren, D.K., Cook, Avery, and Wing, B.R., 2017, Greater sage-grouse resource selection drives reproductive fitness under a conifer removal strategy: Rangeland Ecology \& Management, v. 70, no. 1, p. 59-67. [Also available at https://doi. org/10.1016/j.rama.2016.09.002.]
Schaub, Michael, and Abadi, Fitsum, 2011, Integrated population models - A novel analysis framework for deeper insights into population dynamics: Journal of Ornithology, v. 152 , no. 1, p. 227-237. [Also available at https://doi. org/10.1007/s10336-010-0632-7.]

Schlaepfer, D.R., Taylor, K.A., Pennington, V.E., Nelson, K.N., Martyn, T.E., Rottler, C.M., Lauenroth, W.K., and Bradford, J.B., 2015, Simulated big sagebrush regeneration supports predicted changes at the trailing and leading edges of distribution shifts: Ecosphere, v. 6, no.1, art. 3. [Also available at https://doi.org/10.1890/ES14-00208.1.]

Schreiber, L.A., Hansen, C.P., Rumble, M.A., Millspaugh, J.J., Gamo, R.S., Kehmeier, J.W., and Wojcik, Nate, 2015, Microhabitat selection of brood-rearing sites by greater sage-grouse in Carbon County, Wyoming: Western North American Naturalist, v. 75, no. 3, p. 348-363. [Also available at https://doi.org/10.3398/064.075.0312.]

Schroeder, M.A., Aldridge, C.L., Apa, A.D., Bohne, J.R., Braun, C.E., Bunnell, S.D., Connelly, J.W., Deibert, P.A., Gardner, S.C., Hilliard, M.A., and Kobriger, G.D., 2004, Distribution of sage-grouse in North America: The Condor, v. 106, no. 2, p. 363-376. [Also available at https://doi. org $/ 10.1650 / 7425$.

Schroeder, M.A., and Baydack, R.K., 2001, Predation and management of prairie grouse: Wildlife Society Bulletin, v. 29, no. 1, p. 24-32. [Also available at https://www.jstor. org/stable/3783977.]

Schroeder, M.A., and Robb, L.A., 2003, Fidelity of greater sage-grouse Centrocercus urophasianus to breeding areas in a fragmented landscape: Wildlife Biology, v. 9, no. 4, p. 291-299.

Schroeder, M.A., Young, J.R., and Braun, C.E., 1999, Sage grouse (Centrocercus urophasianus), in Poole, A., and Gill, F., eds., The birds of North America: Philadelphia, Pa., The Birds of North America, Inc., no. 425, 28 p. [Also available at https://birdsna.org/Species-Account/bna/species/saggro/ introduction.]

Scott, J.W., 1942, Mating behavior of the sage grouse: The Auk, v. 59, no. 4, p. 477-498.

Sedinger, J.S., White, G.C., Espinosa, Shawn, Partee, E.T., and Braun, C.E., 2010, Assessing compensatory versus additive harvest mortality-An example using greater sage-grouse: Journal of Wildlife Management, v. 74, no. 2, p. 326-332. [Also available at https://doi.org/10.2193/2009-071.]

Severson, J.P., Hagen, C.A., Maestas, J.D., Naugle, D.E., Forbes, J.T., and Reese, K.P., 2017a, Effects of conifer expansion on greater sage-grouse nesting habitat selection: Journal of Wildlife Management, v. 81, no. 1, p. 86-95. [Also available at https://doi.org/10.1002/jwmg.21183.] 
Severson, J.P., Hagen, C.A., Maestas, J.D., Naugle, D.E., Forbes, J.T., and Reese, K.P., 2017b, Restoring sage-grouse nesting habitat through removal of early successional conifer: Restoration Ecology, v. 25, no. 6, p. 1026-1034. [ Also available at https://doi.org/10.1111/rec.12524.]

Severson, J.P., Hagen, C.A., Maestas, J.D., Naugle, D.E., Forbes, J.T., and Reese, K.P., 2017c, Short-term response of sage-grouse nesting to conifer removal in the northern Great Basin: Rangeland Ecology \& Management, v. 70, no. 1, p. 50-58. [Also available at https://doi.org/10.1016/j. rama.2016.07.011.]

Severson, J.P., Hagen, C.A., Tack, J.D., Maestas, J.D., Naugle, D.E., Forbes, J.T., and Reese, K.P., 2017d, Better living through conifer removal - A demographic analysis of sagegrouse vital rates: PloS ONE, v. 12, no. 3, art. e0174347, accessed December 2017 at https://doi.org/10.1371/journal. pone. 0174347 .

Shi, Hua, Rigge, Matthew, Homer, C.G., Xian, George, Meyer, D.K., and Bunde, Brett, 2017, Historical cover trends in a sagebrush steppe ecosystem from 1985 to 2013-Links with climate, disturbance, and management: Ecosystems, p. 1-17, accessed December 2017 at https://doi. org/10.1007/s10021-017-0191-3.

Shinneman, D.J., and McIlroy, S.K., 2016, Identifying key climate and environmental factors affecting rates of postfire big sagebrush (Artemisia tridentata) recovery in the northern Columbia Basin, USA: International Journal of Wildland Fire, v. 25, no. 9, p. 933-945. [Also available at https://doi.org/10.1071/WF16013.]

Shirk, A.J., Schroeder, M.A., Robb, L.A., and Cushman, S.A., 2015, Empirical validation of landscape resistance models: insights from the greater sage-grouse (Centrocercus urophasianus): Landscape Ecology, v. 30, no. 10, p. 1837-1850. [Also available at https://doi.org/10.1007/s10980-015-02144.]

Shirk, A.J., Schroeder, M.A., Robb, L.A., and Cushman, S.A., 2017, Persistence of greater sage-grouse in agricultural landscapes: Journal of Wildlife Management, v. 81, no. 5, p. 905-918. [Also available at https://doi.org/10.1002/ jwmg.21268.]

Smith, J.A., and Dwyer, J.F., 2016, Avian interactions with renewable energy infrastructure-An update: The Condor, v. 118, no. 2, p. 411-423. [Also available at https://doi. org/10.1650/CONDOR-15-61.1.]

Smith, J.T., Evans, J.S., Martin, B.H., Baruch-Mordo, S., Kiesecker, J.M., and Naugle, D.E., 2016a, Reducing cultivation risk for at-risk species-Predicting outcomes of conservation easements for sage-grouse: Biological Conservation, v. 201, p. 10-19. [Also available at https://doi.org/10.1016/j. biocon.2016.06.006.]
Smith, J.T., Tack, J.D., Berkeley, L.I., Szczypinski, Mark, and Naugle, D.E., 2017a, Effects of rotational grazing management on nesting greater sage-grouse: Journal of Wildlife Management, v. 82, no. 1, p. 103-112. [Also available at https://doi.org/10.1002/jwmg.21344.]

Smith, J.T., Tack, J.D., Doherty, K.E., Allred, B.W., Maestas, J.D., Berkley, L.I., Dettenmaier, S.J., Messmer, T.A., and Naugle, D.E., 2017b, Phenology largely explains taller grass at successful nests in greater sage-grouse: Ecology and Evolution, v. 8, no. 1, p. 356-364. [Also available at https:// doi.org/10.1002/ece3.3679.]

Smith, K.T., and Beck, J.L., 2017, Sagebrush treatments influence annual population change for greater sage-grouse: Restoration Ecology, accessed December 2017 at https:// doi.org/10.1111/rec.12589.

Smith, K.T., Beck, J.L., and Pratt, A.C., 2016b, Does Wyoming's core area policy protect winter habitats for greater sage-grouse?: Environmental Management, v. 58, no. 4, p. 585-596. [Also available at https://doi.org/10.1007/ s00267-016-0745-8.]

Soranno, P.A., Cheruvelil, K.S., Bissell, E.G., Bremigan, M.T., Downing, J.A., Fergus, C.E., Filstrup, C.T., Henry, E.N., Lottig, N.R., Stanley, E.H., Stow, C.A., Tan, P.N., Wagner, Tyler, and Webster, K.E., 2014, Cross-scale interactions-Quantifying multi-scaled cause-effect relationships in macrosystems: Frontiers in Ecology and the Environment, v. 12, no. 1, p. 65-73. [Also available at https://doi. org/10.1890/120366.]

Spence, E.S., Beck, J.L., and Gregory, A.J., 2017, Probability of lek collapse is lower inside sage-grouse core areas - Effectiveness of conservation policy for a landscape species: PloS ONE, v. 12, no. 11, art. e0185885, accessed December 2017 at https://doi.org/10.1371/journal. pone. 0185885 .

Stavros, E.N., Abatzoglou, J.T., McKenzie, Donald, and Larkin, N.K., 2014, Regional projections of the likelihood of very large wildland fires under a changing climate in the contiguous Western United States: Climatic Change, v. 126, no. 3-4, p. 455-468. [Also available at https://doi. org/10.1007/s10584-014-1229-6.]

Stevens, B.S., Connelly, J.W., and Reese, K.P., 2012, Multiscale assessment of greater sage-grouse fence collision as a function of site and broad scale factors: Journal of Wildlife Management, v. 76, no. 7, p. 1370-1380. [Also available at https://doi.org/10.1002/jwmg.397.]

Stevens, B.S., Naugle, D.E., Connelly, J.W., Griffiths, T., and Reese, K.P., 2013, Mapping sage-grouse fence-collision risk-Spatially explicit models for targeting conservation implementation: Wildlife Society Bulletin, v. 37, no. 2, p. 409-415. [Also available at https://doi.org/10.1002/ wsb.273.] 
Stevens, B.S., Reese, K.P., and Connelly, J.W., 2011, Survival and detectability bias of avian fence collision surveys in sagebrush steppe: Journal of Wildlife Management, v. 75, no. 2, p. 437-449. [Also available at https://doi.org/10.1002/ jwmg.53.]

Stevens, Richard, 2004, Establishing plants by transplanting and interseeding, in Monsen, S.B., Stevens, Richard, and Shaw, N.L., comps., Restoring western ranges and wildlands: Fort Collins, Colo., U.S. Forest Service, Rocky Mountain Research Station, General Technical Report RMRS-GTR-136, v. 3, p. 739-744. [Also available at https://www.fs.usda.gov/treesearch/pubs/31975.]

Still, S.M., and Richardson, B.A., 2015, Projections of contemporary and future climate niche for Wyoming big sagebrush (Artemisia tridentata subsp. wyomingensis) - A guide for restoration: Natural Areas Journal, v. 35, no. 1, p. 30-43. [Also available at https://doi.org/10.3375/043.035.0106.]

Stiver, S.J., Apa, A.D., Bohne, J.R., Bunnell, S.D., Deibert, P.A., Gardner, S.C., Hilliard, M.A., McCarthy, C.W., and Schroeder, M.A., 2006, Greater sage-grouse comprehensive conservation strategy: Cheyenne, Wyo., Western Association of Fish and Wildlife Agencies, 442 p., accessed December 2017 at https://wdfw.wa.gov/publications/01317/ wdfw01317.pdf.

Stiver, S.J., Rinkes, E.T., Naugle, D.E., Makela, P.D., Nance, D.A., and Karl, J.W., 2015, Sage-grouse habitat assessment framework-Multi-scale habitat assessment tool: Denver, Colo., Bureau of Land Management and Western Association of Fish and Wildlife Agencies, Technical Reference 6710-1, $114 \mathrm{p}$.

Stonehouse, K.F., Shipley, L.A., Lowe, J., Atamian, M.T., Swanson, M.E., and Schroeder, M.A., 2015, Habitat selection and use by sympatric, translocated greater sage-grouse and Columbian sharp-tailed grouse: Journal of Wildlife Management, v. 79, no. 8, p. 1308-1326. [Also available at https://doi.org/10.1002/jwmg.990.]

Sveum, C.M., Crawford, J.A., and Edge, W.D., 1998a, Use and selection of brood-rearing habitat by sage grouse in south central Washington: Great Basin Naturalist, v. 58, no. 4, p. 344-351. [Also available at https://www.jstor.org/ stable/41713072.]

Sveum, C.M., Edge, W.D., and Crawford, J.A., 1998b, Nesting habitat selection by sage grouse in southcentral Washington: Journal of Range Management, v. 51, no. 3, p. 265-269. [Also available at https://journals.uair.arizona.edu/index. $\mathrm{php} / \mathrm{jrm} /$ article/view/9310.]
U.S. Department of Agriculture Forest Service, 2015a, Greater sage-grouse record of decision for Idaho and southwest Montana, Nevada, and Utah and land management plan amendments for the Ashley National Forest, BeaverheadDeerlodge National Forest, Boise National Forest, Caribou National Forest, Challis National Forest, Curlew National Grassland, Dixie National Forest, Fishlake National Forest, Humboldt National Forest, Manti-La Sal National Forest, Salmon National Forest, Sawtooth National Forest, Targhee National Forest, Toiyabe National Forest, Uinta National Forest, Wasatch-Cache National Forest: U.S. Department of Agriculture, September 2015, 272 p.

U.S. Department of Agriculture Forest Service, 2015b, Greater sage-grouse record of decision for northwest Colorado and Wyoming and land management plan amendments for the Routt National Forest, Thunder Basin National Grassland, Bridger-Teton National Forest, Medicine Bow National Forest: U.S. Department of Agriculture, September 2015, $182 \mathrm{p}$.

U.S. Department of the Interior, 2005, Endangered and threatened wildlife and plants; 12 -month finding for petitions to list the greater sage-grouse as threatened or endangered; proposed rule: U.S. Fish and Wildlife Service, Department of Interior, 70 CFR, p. 2244-2282.

U.S. Department of the Interior, 2010, Endangered and threatened wildlife and plants; 12 -month findings for petitions to list the greater sage-grouse (Centrocercus urophasianus) as threatened or endangered: U.S. Fish and Wildlife Service, Department of Interior, 75 CFR, p. 13910-14014.

U.S. Department of the Interior, 2015a, An integrated rangeland fire management strategy-The final report to the Secretary: Washington, D.C., U.S. Department of the Interior, $94 \mathrm{p}$.

U.S. Department of the Interior, 2015b, Endangered and threatened wildlife and plants; 12 -month finding on a petition to list greater sage-grouse (Centrocercus urophasianus) as an endangered or threatened species: U.S. Fish and Wildlife Service, Department of Interior, 80 CFR, p. 59857-59942.

U.S. Fish and Wildlife Service, 2013, Greater sage-grouse (Centrocercus urophasianus) conservation objectivesFinal report: Denver, Colo., U.S. Department of the Interior, Fish and Wildlife Service, 91 p., accessed December 4, 2017, at https://www.fws.gov/greatersagegrouse/documents/ COT-Report-with-Dear-Interested-Reader-Letter.pdf. 
Van Lanen, N.J., Green, A.W., Gorman, T.R., Quattrini, L.A., and Pavlacky, D.C., Jr., 2017, Evaluating efficacy of fence markers in reducing greater sage-grouse collisions with fencing: Biological Conservation, v. 213, p. 70-83. [Also available at https://doi.org/10.1016/j.biocon.2017.06.030.]

Walker, B.L., Apa, A.D., and Eichhoff, Karin, 2016, Mapping and prioritizing seasonal habitats for greater sage-grouse in northwestern Colorado: Journal of Wildlife Management, v. 80, no. 1, p. 63-77. [Also available at https://doi. org/10.1002/jwmg.962.]

Walker, B.L., Naugle, D.E., and Doherty, K.E., 2007, Greater sage-grouse population response to energy development and habitat loss: Journal of Wildlife management, v. 71, no. 8, p. 2644-2654. [Also available at https://doi. org/10.2193/2006-529.]

Western Association of Fish and Wildlife Agencies, 2015, Greater sage-grouse population trends-An analysis of lek count databases 1965-2015: Cheyenne, Wyo., Western Association of Fish and Wildlife Agencies, 55 p. [Also available at http://www.wafwa.org/Documents\%20and $\% 20$ Settings/37/Site\%20Documents/News/Lek\%20Trend\%20 Analysis\%20final\%208-14-15.pdf.]

Westover, Matthew, Baxter, Jared, Baxter, Rick, Day, Casey, Jensen, Ryan, Petersen, Steve, and Larsen, Randy, 2016, Assessing greater sage-grouse selection of brood-rearing habitat using remotely-sensed imagery - Can readily available high-resolution imagery be used to identify broodrearing habitat across a broad landscape?: PloS ONE, v. 11, no. 5, art. e0156290, accessed December 2017 at https://doi. org/10.1371/journal.pone.0156290.

Whisenant, S.G., 1990, Changing fire frequencies on Idaho Snake River plains-Ecological and management implications, in McArthur, E.D., Romney, E.M., Smith, S.D., and Tueller, P.T., comps., Proceedings - Symposium on cheatgrass invasion, die-off, and other aspects of shrub biology and management: Ogden, Utah, U.S. Department of Agriculture, Forest Service, Intermountain Research Station, General Technical Report INT-276, p. 4-10. [Also available at https://www.fs.usda.gov/treesearch/pubs/40669.]

Wiens, J.A., 1989, Spatial scaling in ecology: Functional Ecology, v. 3, no. 4, p. 385-397. [Also available at https://www. jstor.org/stable/2389612.]

Wing, B.R., and Messmer, T.A., 2016, Impact of sagebrush nutrients and monoterpenes on greater sage-grouse vital rates: Human-Wildlife Interactions, v. 10, no. 2, p. 157-168. [Also available at https://digitalcommons.usu.edu/hwi/ vol10/iss $2 / 4 /$.
Wisdom, M.J., Meinke, C.W., Knick, S.T., and Schroeder, M.A., 2011, Factors associated with extirpation of sagegrouse, in Knick, S.T., and Connelly, J.W., eds., Greater sage-grouse ecology and conservation of a landscape species and its habitats: Berkeley, Calif., University of California Press, Studies in Avian Biology, no. 38, p. 451-472.

Wrobleski, D.W., and Kauffman J.B., 2003, Initial effects of prescribed fire on morphology, abundance, and phenology of forbs in big sagebrush communities in southeastern Oregon: Restoration Ecology, v. 11, no. 1, p. 82-90. [Also available at https://doi.org/10.1046/j.1526100X.2003.00084.x.]

Xian, G.Z., Homer, Collin, Rigge, M.B., Shi, Hua, and Meyer, Debbie, 2015, Characterization of shrubland ecosystem components as continuous fields in the northwest United States: Remote Sensing of Environment, v. 168, p. 286-300. [Also available at https://doi.org/10.1016/j. rse.2015.07.014.]

Zabihi, Khodabakhsh, Paige, G.B., Hild, A.L., Miller, S.N., Wuenschel, Amarina, and Holloran, M.J., 2017, A fuzzy logic approach to analyse the suitability of nesting habitat for greater sage-grouse in western Wyoming: Journal of Spatial Science, v. 62, no. 2, p. 215-234. [Also available at https://doi.org/10.1080/14498596.2017.1292965.]

For more information about this publication, contact

Sage-Grouse and Sagebrush Ecosystem Program

U.S. Geological Survey

12201 Sunrise Valley Dr.

Mail Stop 301

Reston, VA 20192

For additional information visit https://www.usgs.gov/science/missionareas/ecosystems/sage-grouse-sagebrush-steppe

Publishing support provided by the

Rolla Publishing Service Center 



\section{$\frac{1}{8}$}

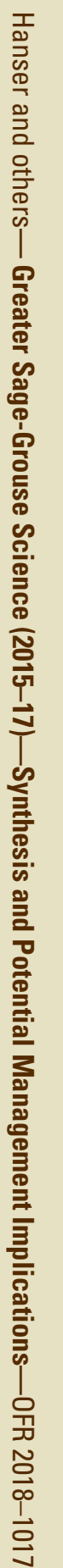

